\author{
UNITED STATES \\ DEPARTMENT OF THE INTERIOR \\ GEOLOGICAL SURVEY
}

\title{
U.S. GEOLOGICAL SURVEY OIL AND GAS RESOURCE INVESTIGATIONS PROGRAM
}

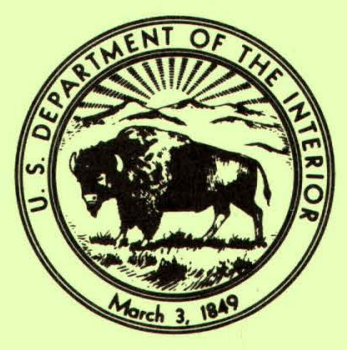

Open-File Report 78-303

This report is preliminary and has not been edited or reviewed for conformity with U.S. Geological Survey standards or nomenclature.

Denver, Colorado

December, 1977 


\title{
UNITED STATES DEPARTMENT OF THE INTERIOR
} GEOLOGICAL SURVEY

U.S. GEOLOGICAL SURVEY OIL AND GAS RESOURCE INVESTIGATIONS PROGRAM

\author{
R. F. Mast \\ Denver, Colorado \\ December, 1977
}

Open-File Report 78-303

1978

This report is preliminary and has not been edited or reviewed for conformity with U.S. Geological Survey standards or nomenclature. 

PREFACE------

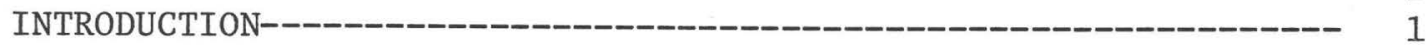

National problems--_-_-_-_-_- 1

Program objectives and rationale-_-_-_-_-_-_-_-_ 4

Federal authorization for program--_-_-_-_--_---_---- 5

ORGANIZATION OF THE BRANCH OF OIL AND GAS RESOURCES----------- 6

History and staffing of the program--_--_---_---_---- 6

Program strategy-_-_-_-_-_-_-_-_-_-_-_-_-_-_-_-_-- 7

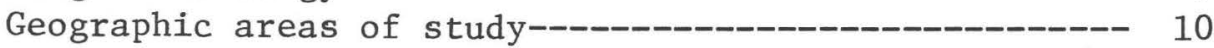

PRINCIPAL FIELDS OF RESEARCH--_-_-_-_-_-_-_-_-_-_-_-_-_-_--- 10

Regiona1 Petroleum Geology-_-_-_-_-_-_-_-_-_-_-_-_ 10

Onshore basin studies-_-_-_-_-_-_-_-_-_-_-_-_-- 10

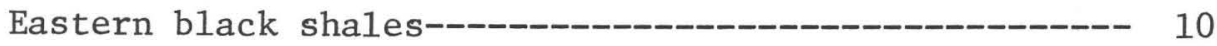

Western tight gas sands-_-_-_-_-_-_-_-_-_-_-_------ 12

Northern Alaska petroleum geology-_-_-_-_-_-_------ 13

Continental Margin Petroleum Resources------------- 14

Topical Petroleum Geology-_-_-_-_-_-_-_-_-_-_-_--_-_---- 15

Oil forming processes--_-_-_-_-_-_-_-_-_-_-_-_-_-_--- 15

Sedimentary processes and reservoir rocks----_--_------ 15

Structural traps--_-_-_-_-_-_-_-_-_-_-_-_-_-_-_----- 16

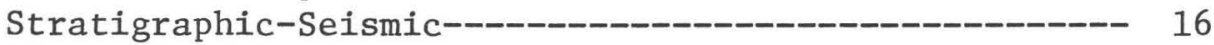

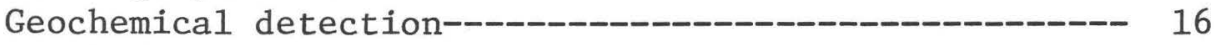

Borehole gravity meter---_---_-_---_---_-------- 17

Resource Analysis--_-_-_-_-_-_-_-_-_-_-_-_-_-_-_-_-_--- 18

0il and gas resource data systems----------------- 18

Resource appraisa1--_--_-_-_---- 19

INTERACTIONS WITH OTHER GOVERNMENT AGENCY AND RESEARCH

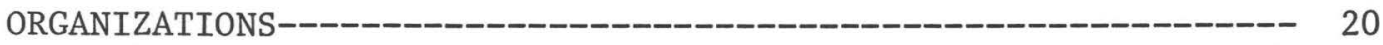

ACCOMPLISHMENTS IN 1976-_-_-_-_-_-_-_-_-_-_-_-_-_-_-_ 22

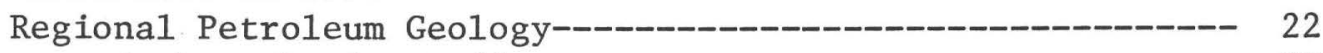

Onshore basin studies--_-_-_--_-_-_-_-_-_-_-_-_-_-_-- 22

Eastern black shale--_-_-_-_-_-_-_-_-_-_---_------- 24

Northern Alaska petroleum geology--_-_-------------- 24

Continental margin petroleum resources--_--_--------- 25

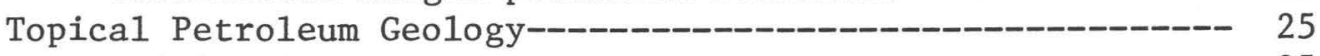

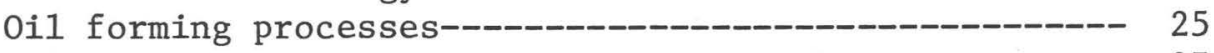

Sedimentary processes and reservoir rocks------------- 27

Structural traps--_-_-_-_-_-_-_-_-_-_-_-_-_-_------ 29

Stratigraphic-Seismic--_-_-_-_-_-_-_-_----------- 29

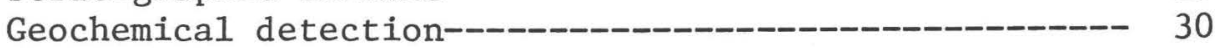

Borehole gravity --_-_-_-_-_-_-_-_-_-_-_-_------ 31

Resource Analysis--_-_-_-_-_-_-_-_-_-_-_-_-_-_-_-_-_--- 31

Oil and gas resource data systems--_-_-_-_-_------ 31

Resource appraisa1--_-_-_-_-_-_-_-_---_----- 32

Opportunities for External Participation-----_-------------- 32

APPENDIX I. ORGANIZATION OF THE U.S. GEOLOGICAL SURVEY,

GEOLOGIC DIVISION, AND THE OFFICE OF ENERGY RESOURCES------ I-1

APPENDIX II. FUNDING AND PERSONNEL FOR OIL AND GAS RESOURCES

INVESTIGATIONS AND PROGRAMS-----_---_---------------- II-1

APPENDIX III. LIST OF RECENT PUBLICATIONS AND REPORTS--------- III-1

APPENDIX IV. ANNOTATED LIST OF PROJECTS BY PROGRAM----------- IV-1 

June 8, 1978

\section{GEOTIMES}

\section{N 161978}

U.S. Geological Survey Oil \& Gas Resource Investigations Program (open-file report 78-303)

is sure to interest readers of Geotimes, the news magazine edited for earth scientists. Before we can list it in our 'new books' section, we must have the price.. Can you help us? A note on this letter will suffice.

\section{Thanks!}

Shaw mash/gth

Sharon Marsh editorial assistant Geotimes

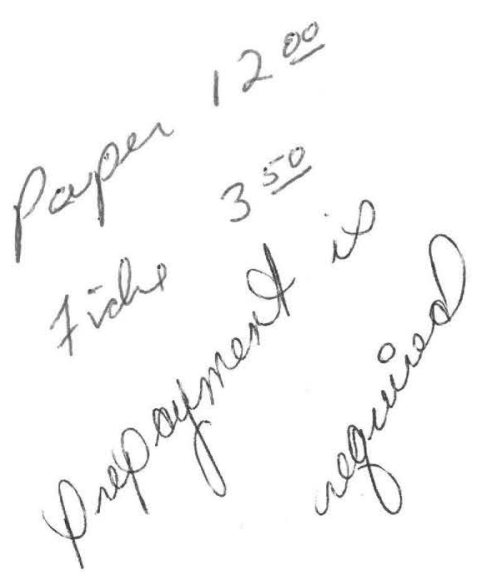

his report (78-303, and we go be the number rather than the title) is available from chis office for $\$ 12.00$ for a paper copy, or $\$ 3.50$ for a microfiche copy. Prepayment is required on a 11 orders. Our mailing address is:

Open File Services Section

USGS

Box 25425, Federal Center

Denver, C0 80225

hecks should be made payable to the USGS. Telephone number is 303-234-5888.

lope this answers al1 your questions. Thank you for your interest.

.L. Ridde11

ist. Clerk, USGS, OFSS 
The decade of the 1970's so far has been marked by a sharply increased dependence by the United States on foreign sources of energy. Although this dependence had been growing for the previous 20 years, it was made clearly visible to the American public by the Arab oil embargo of 1973. Since then, energy has remained a topic of much public discussion and concern.

The current imbalance between U.S. energy supply and demand and the generally recognized need to increase the domestic production of energy make it appropriate to review our present knowledge of U.S. mineral fuel resources-coal, oil, natural gas, oil shale, and uranium. These conditions also warrant a description of the geologic research that is being carried out to improve our understanding of these resources and to determine the effects on the environment of their development.

Energy resource investigations programs are being conducted by the U.S. Geological Survey to assess the Nation's coal, oil and gas, oil shale, and uranium and thorium resources. In addition, two programs in Marine Geology provide information for assessing the petroleum resources of the U.S. Outer Continental Shelf (OCS) and for identifying the environmental factors that could effect their development. This report does not review oil and gas resource assessment programs in marine geology.

The description of the Geological Survey's oil and gas resource investigations is presented in this report in the context of the underlying socio-economic problem of expanding the domestic production of oil and gas while maintaining acceptable environmental standards. This orientation toward a national mission characterizes each segment of the Survey's energy resources and marine geology programs. Readers who want information about the individual projects that compose the oil and gas program will find it in the appendices, which also include a bibliography and appropriate fiscal data.

It is hoped that this report will give scientists, science administrators, and policy makers, both in government and in the private sector as well as the general public, a better understanding of the relation of oil and gas resources to the Nation's requirements for energy, and of the importance of a carefully planned program of resource assessment and environmental research on these vital energy commodities.

\section{INTRODUCTION}

Nationa1 problems

Crude oil and natural gas supplied approximately three-fourths of the energy consumed by the United States in 1977. Domestic proved reserves of oil began declining in 1960, and domestic production of oil began to decline in 1971. Domestic proved reserves of natural gas began declining in 1969 and domestic gas production began to decline in 1974. This decline in domestic oil and gas production, coupled with the growing demand for petroleum in the United States, has markedly increased our dependence on imported oil and gas for energy uses. 
In 1977, the United States imported 3.8 billion barrels of liquid hydrocarbons which was over 50 percent of the country's supply, and imports of natural gas were 1.0 trillion $\mathrm{cu} f t$ or about 5 percent of our natural gas supplies. The cost of these imported commodities in 1977 was in excess of 44 billion dollars. Although much of this cost was related to price increases resulting from the formation of OPEC in 1973 the United States has also increased by almost five times the quantity imported in 1977 as compared to 1960 . This growing dependence on foreign oil and gas over the past 17 years has contributed significantly to current political and economic problems. Solutions to such longstanding problems will not be found easily or quickly. The development of new domestic energy supplies will require long lead times as a result of the massive investments of capital and manpower required by the oil and gas exploration and development process. This is especially true of resources developed in adverse environments of Alaska and offshore. In addition, our changing political climate demands safeguards to protect the environment. These safeguards limit the rate at which new energy resources can be explored and developed or, in some cases, limit the potential for exploration and development of new energy resources. From the environmental point of view, however, production of oil and gas through wells has many advantages when compared with the development of other kinds of fossil energy resources.

In the United States the annual historical drilling and discovery data indicate that the volumes of oil and gas discovered per exploratory-well drilled have declined greatly over the past 40 years. An exception to this is the discovery of the giant Prudhoe Bay field in northern Alaska in 1968. Examples of the decline in discovery rates for drilling in the onshore conterminous United States for both oil and gas are shown in figure 1. Even though exploratory drilling has increased from a low point in 1971, the volumes discovered each year have not replaced the oil and gas we produce annually. Consequently domestic production and petroleum reserves are declining. In order to halt or reverse this decline in domestic reserves we will have to

1) Improve exploration efficiency through development of new and more effective exploration techniques.

2) Drill in frontier areas where the exploration potential is high.

3) Greatly increase the amount of exploratory drilling.

4) Improve the recovery from known oil and gas accumulations through the development of new production technology and recovery techniques.

Each of the above could make a significant contribution to the Nation's future energy supplies from oil and gas and it is essential for government to understand the potential magnitude of these contributions in order to develop sound energy policies.

Much of the responsibility for national goal setting and planning lies with government. However, for government to be able to meet these responsibilities, and to develop and defend long-range energy plans, it must posses adequate resource information and have confidence that its sources of information are reliable. Resource studies are needed to develop policy related to international matters such as international boundary disputes and the purchase of foreign supplies, and detailed resource studies are needed as input to a variety of economic, supply, and planning models. Results from such model studies are important because they form the base upon which government planning and policy decisions are made; for example, decisions must be made and policy 

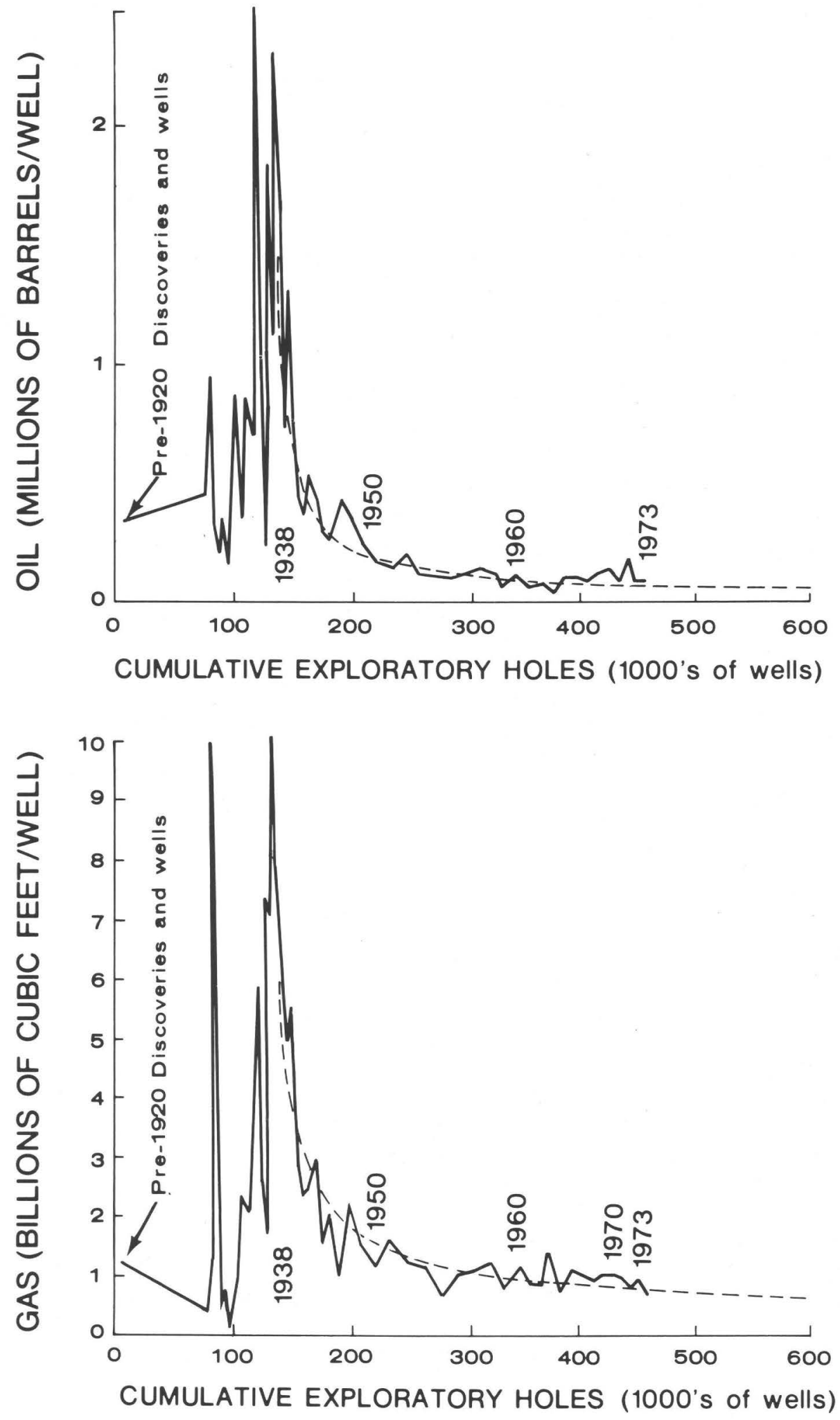

Figure 1.--Historic and Predicted Future Relationship between Oil and Gas Discoveries and Exploratory Holes, Onshore U.S. 
constructed, to manage the federal lands and determine which should be leased for oil and gas as well as mineral exploration and development, and which should be reserved as wilderness in national forests, wildlife refuges, and national parks. In addition, the rate at which Federal lands are leased should constantly be evaluated to insure adequate room will be available for exploration for needed resources.

We know that conventional oil and gas supplies are not endless, and that eventually we must shift to other energy sources--coal, oil shale, tar sands, geothermal, nuclear, and solar. But development of such alternate energy sources also requires extensive lead time and major capital investment. During the transition period to a broader base of energy resources we must maximize our domestic oil and gas supply and (or) reduce consumption so as to reduce foreign supply dependency. Nevertheless, it is clear that oil and gas can only "buy time" in which to complete the transition. But how much time do we have? How much oil and gas remain to be discovered? What proportion is offshore and what onshore? What domestic policies would best promote optimum development and use of remaining U.S. oil and gas resources? What foreign policies should the Nation adopt in deference to its domestic supply situation over the next few decades? Answers to many of these questions depend in large measure on reliable and detailed knowledge of our domestic undiscovered oil and gas resources.

\section{Program objectives and rationale}

Throughout the entire history of oil and gas development there has been serious disagreement between qualified resource experts about how much oil and gas remains to be discovered and which prediction techniques give the most reliable estimates. In recent years estimates of oil and gas resources for the nation as a whole seem to be converging. However, there is still considerable controversy about how much oil and gas remain to be discovered and in which areas it will be found. Although some of these differences of opinion can be explained on the basis of data input and the methods and assumptions used in making the appraisals; many cannot. There is honest disagreement about the magnitude of our resource base.

Resource appraisal must be a continuing effort. New data must be gathered and new appraisal techniques must be developed to improve our ability to estimate undiscovered resources and to update previous estimates. The methods employed by geoscientists to estimate undiscovered resources are, in general, based on analogues from other basins or areas which have been heavily explored. The knowledge and concepts developed about the occurrence and distribution of hydrocarbons in these analogue areas is then applied in a variety of ways to develop undiscovered resource estimates for less heavily drilled or unknown areas. The reliability of resource estimates in frontier areas depends in large measure on the prediction of the modes of occurrence for petroleum in the area and the selection of appropriate analogues to be used in making resource assessments on the basis of geologic knowledge. The whole process is iterative; as new data are collected in the area of interest new concepts about hydrocarbon occurrence (sometimes referred to as plays) are developed and new analogues must be selected and applied. In general terms the better our knowledge of the modes of occurrence, and the better our understanding of the geologic factors which control how rich the known petroleum producing areas are, the better our ability to predict the magnitude of undiscovered resources in frontier or developing regions. 
The principal objective of the U.S. Geological Survey's investigations of oil and gas resources is to provide government and the public with modern up to date assessments of our nation's oil and gas resources. To this end the program supports the development of appraisal methodologies and the appraisal of the nation's oil and gas resources through its Resource Appraisal Group. Topical and regional petroleum-related geologic studies play a vital role in this program. These studies have as a common objective the gathering and the analysis of geologic, geophysical, and geochemical data to develop information and concepts concerning petroleum occurrence and genesis needed to support the resource appraisal efforts. Finally data systems are being developed with the objective of organizing much of our petroleum-related geologic knowledge so that it can be rapidly retrieved and applied to all of our resource investigations. An additional objective of our data systems program is to make public as rapidly as possible all government-generated data and information.

Currently the oil and gas resources program is designed to evaluate undiscovered resources on a basin or provence scale. As time goes on it is our intention to develop the tools and data necessary to develop petroleum resource appraisals on a more detailed basis and eventually to the "play" level. It is not our intention to become involved in small tract or lease evaluation; in the U.S. Geological Survey, that is the responsibility of the Conservation Division.

Federal authorization for program

The basic mandate for the oil and gas program is the Organic Act that established the U.S. Geological Survey in 1879. This Act (43 U.S.C. 31 (a)) authorizes the Survey to examine "the geological structure, mineral resources, and products of the national domain." More recent authorizations permit the Geological Survey to "conduct geological and geophysical exploration in the Outer Continental Shelf" (43 U.S.C. 1340) and in areas outside the national domain "where determined by the Secretary (of the Interior) to be in the national interest" (43 U.S.C. 31(b)).

Several reports commissioned by the President have given impetus to an expanded national program of energy resource assessment. In December 1973, Dixie Lee Ray, then Chairman of the Atomic Energy Commission, submitted to President Nixon a report entitled "The Nation's energy future." One of the recommendations in this report calls for "enlarging the qualitative and quantitative inventory of domestic resources" as rapidly as possible by improving the "knowledge level of domestic resources and economically available reserves of oil and gas, both onshore and offshore," "the knowledge level of domestic resources...of uranium and thorium," the assessment of "the quality, regional distribution, and recoverability" of the Nation's coal resources, and the "information base on the distribution and quality of oil shales and tar sands." The Project Independence report of November 1974, also commissioned by President Nixon, does not recommend specific policy actions concerning energy but does note that "the new oil production is forecast from frontier areas in Alaska, from the Atlantic OCS or from improved tertiary recovery techniques. Each of these requires further exploration or new technology." Elsewhere in the Project Independence report, the current level of uranium resources and exploratory activities are recognized as constraints to the future expansion of nuclear power. Although these reports have not resulted in additional legislation for the Geological Survey to conduct mineral fuel resources investigations, they have perhaps influenced the Congress to appropriate additional funds for such work under existing statutory authority. 
The President's budget, as submitted to Congress each year, recommends an amount of money to be appropriated to support the Geological Survey's oil and gas resource investigations. A justification that accompanies the budget describes the program, tells how it relates to a national mission or goal, and defines the type and amount of work to be accomplished with the appropriated funds.

As reported in the budget justification for fiscal year 1977, the principal objectives of the oil and gas program are 1) to provide continuously improved and scientifically based assessments of the Nation's oil and gas resources, and 2) to develop and publish exploration guides and techniques to assist and stimulate industry in the search for new oil and gas fields. Resource assessment studies are undertaken in support of the efficient and timely development of U.S. petroleum resources, through distribution of the research results to government planners, the petroleum industry and the general public. The work related to exploration technology is designed to gain new knowledge that will improve the success rate of exploratory drilling.

\section{ORGANIZATION OF THE BRANCH OF OIL AND GAS RESOURCES}

History and staffing of the program

The Branch of $0 i 1$ and Gas Resources was established in the Geologic Division of the U.S. Geological Survey in April of 1973. The organization chart for the Survey and the Branch position in the organization are shown in Appendix I. Prior to 1973, the responsibility for the Survey's Geologic Division oil and gas studies was with the Organic Fuels and Chemical Resources Branch. The Branch of $0 i 1$ and Gas Resources was given the responsibility for formulating new Geologic Division programs on oil and gas resources and works jointly with the Pacific-Arctic and the Atlantic-Gulf Marine Branches for oil and gas resource assessment and related environmental studies in U.S. offshore areas. About 12 percent of the Branch of $\mathrm{Oil}$ and Gas Resources personnel work in the offshore OCS oil and gas resource assessment programs.

When the Branch was formed in 1973, there were 30 full-time staff members of which about 20 were professional geologists and chemists. During 1973 and 1974, the permanent staff was increased to about 90 people in anticipation of the impending energy problem, and the new programs which were formulated, organized, and staffed in 1973 and 1974 received new funding in FY 1975. Many of the new staff members had experience in petroleum exploration, exploitation and research, and as a result of that perspective, the new programs developed rapidly.

Figure 2 shows the location, number, and occupational specialties of the Branch of Oil and Gas Resources permanent full- and part-time staff as of the end of calendar year 1977. In addition about 75 temporary employees (university professors, students, and others) worked for the Branch at some time during the year. Of the 74 professionals working in a permanent capacity, 68 percent are geologists, 18 percent are geophysicists, and 11 percent are chemists. Thirty. people or about 27 percent of the total staff work in technical or other support positions. 


\section{Program strategy}

When the Branch was formed it was recognized that new approaches for assessing resources needed to be formulated and an assessment of the Nation's resources had to be accomplished quickly. It was also realized at that time that projects had to be initiated in important oil and gas basins on and offshore so that information and data would be developed that could input more sophisticated resource studies in the future. In addition, topical studies were initiated to study geological and geochemical factors that influence or control the occurrence of petroleum. The initial resource studies had to be based on whatever data was available to us at the time. The strategy was to develop and (or) collect new data and critically needed information concurrently with resource appraisal studies so as to constantly improve our ability to estimate resources.

Initially the program could only focus on conventional oil and gas resources which would be potential supplies in the near and intermediate term. It was recognized, however, that some of the subeconomic petroleum accumulations in the United States, potential intermediate or long-term resources, could have an important influence on our future domestic energy supplies. Because knowledge and understanding about the magnitude and potential for those kinds of resources are critical in future energy planning, programs were initiated to begin gathering data needed to estimate their future resource potential. Approximately one third of our work is now directed toward the study of intermediate to longterm resources.

Figure 3 shows the program organization of our oil and gas resources studies. These programs fall into three major areas of activity:

Regional Petroleum Geology, Topica1 Petroleum Geology, and Resource Analysis.

The programs in the area of Regional Petroleum Geology are staffed by teams of professionals that have the specialties required to solve specific regional petroleum problems. The program teams are organized to study specific petroleum problems in particular geologic basins, provinces, or regions. Many of the people working in these programs are drawn from the programs listed under Topical Petroleum Geology. In this way specialists can be provided to the regional projects as required to solve particular geologic problems.

In contrast, projects in programs in the area of Topical Petroleum Geology are generally staffed with specialists working on specific petroleum-related topics that have broader geographic application than an individual region or province.

Programs in Resource Analysis are grouped separately because of their national character. The project on $0 i 1$ and Gas Resource Data Systems oversees the organization and development of the basic data upon which other programs operate. The Resource Appraisal Group has the twin responsibility of research in resource assessment methodology, and in assembling the pertinent geologic data from regional and topical petroleum studies, for purposes of producing on a basin scale, geologically-based, probabilistic, numerical appraisals of the nation's oil and gas resources. 


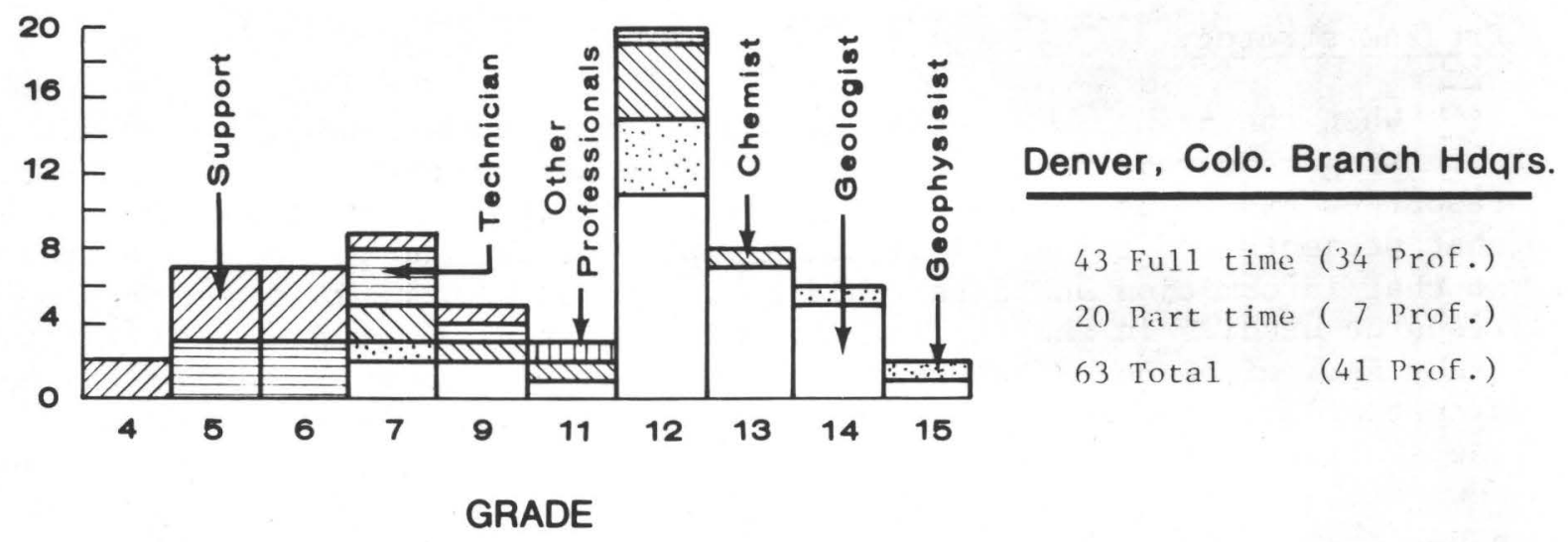

Reston, Va.
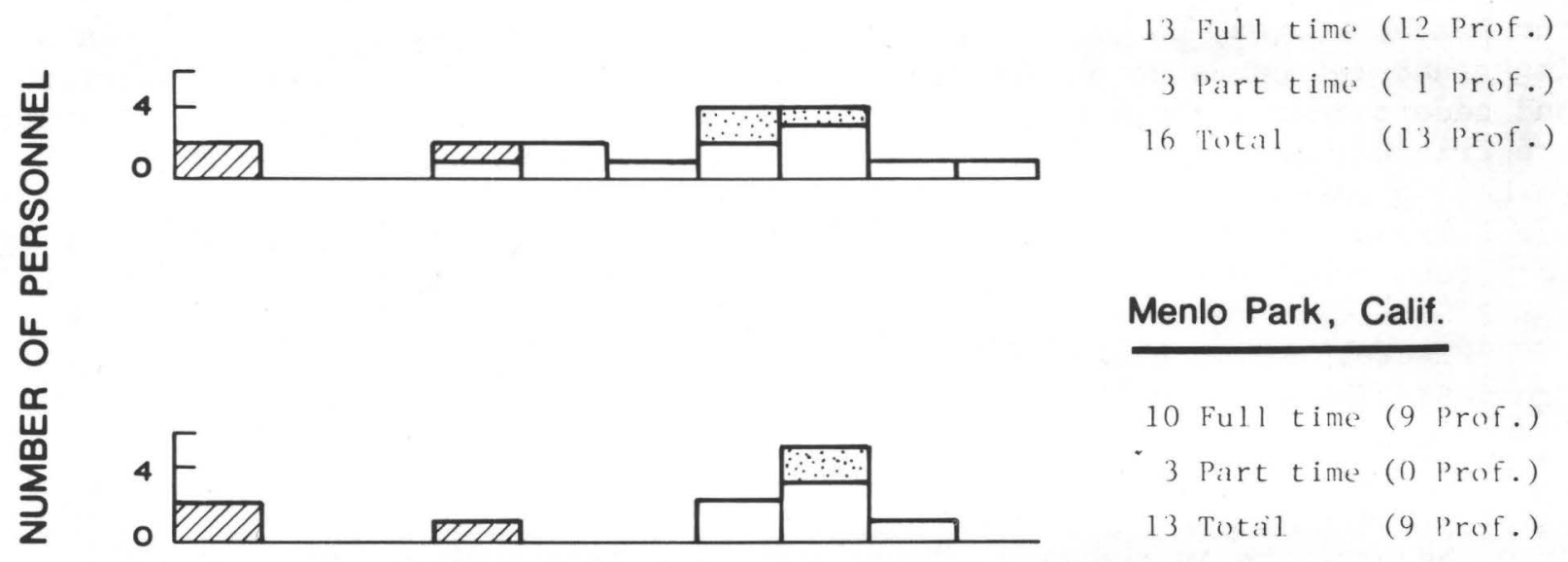

Menlo Park, Calif.
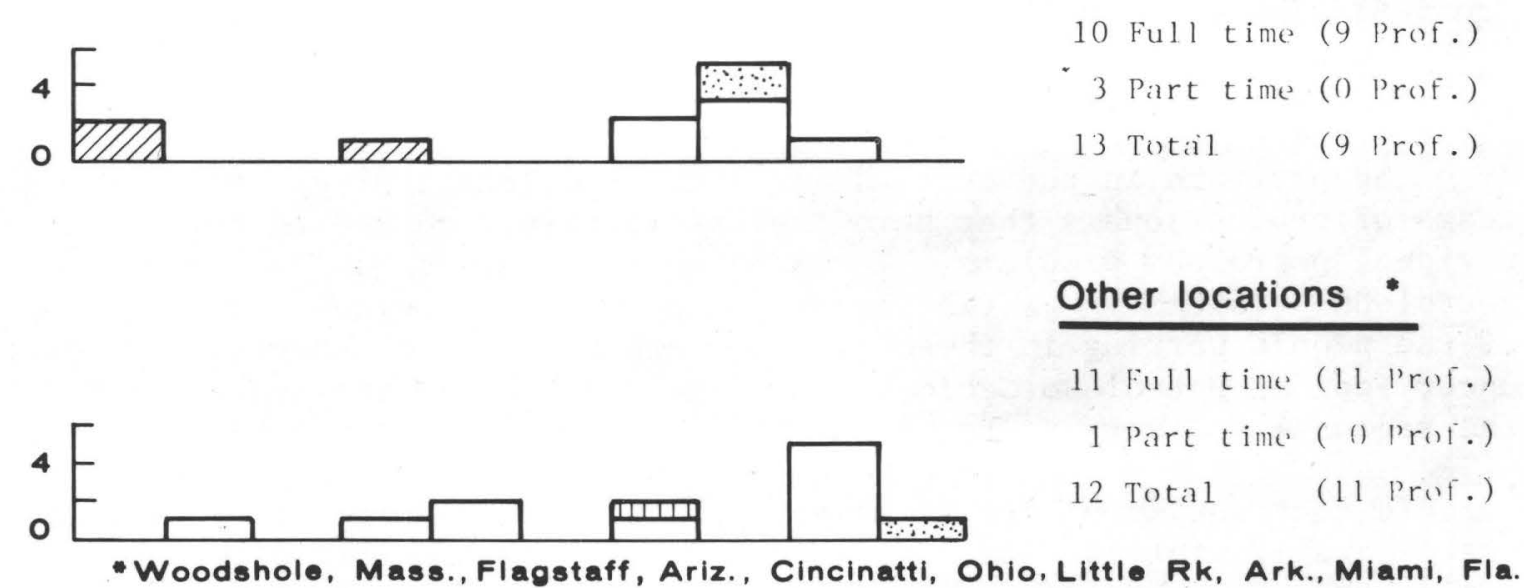

Total Branch

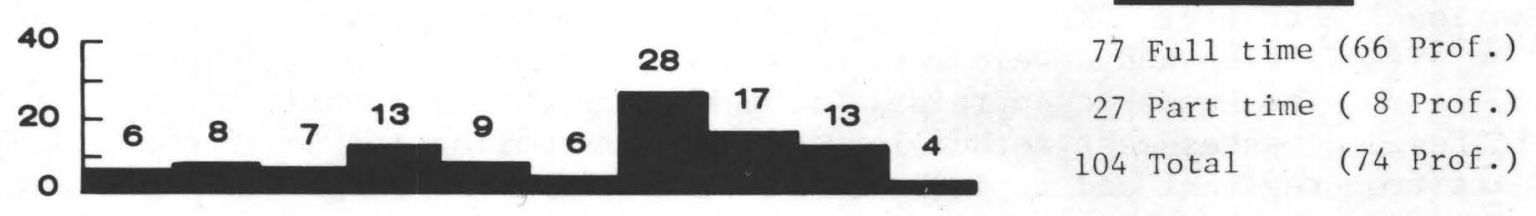

Figure 2. Branch of Oil and Gas Resources Permanent Full and Part Time Staff 


\section{REGIONAL PETROLEUM GEOLOGY}

Onshore Basin Studies (OB)

Charles Spencer

Denver, Co.

Eastern Black Shales (ES)

Wallace deWitt Jr.

Reston, Va.

Western Tight Gas Sands (TG)

Charles Spencer

Denver, Co.

Pacific-Arctic Petroleum Geology (PA)

Harry Cook

Men1o Park, Ca.

Atlantic-Gulf Petroleum Geology (AG)

Robert Mattick

Reston, Va.

Northern Alaska Petroleum Geology (NA)

Kenneth Bird

Menlo Park, Ca.

\section{TOPICAL PETROLEUM GEOLOGY}

Oil Forming Processes (G) George Claypoo1

Denver, Co.

Reservoir Rocks (R) and Sedimentary Processes (P)

Peter Scholle, Denver, Co.

Structural Traps (T)

Wallace deWitt Jr. Reston, Va.

Seismic Stratigraphic Studies (S)

Alfred Balch

Denver, Co.

Geochemical Detection (D)

Terrence Donovan

Flagstaff, $\mathrm{Az}$.

Borehole Gravity (B)

James Schmoker

Denver, Co.
RESOURCE ANALYSIS

Resource Appraisal Group (RAG)

Betty Miller

Denver, Co.

Oil and Gas Resource

Data Systems (OGS)

William Mallory, Denver, Co.

FIGURE 3.--BRANCH OF OIL AND GAS RESOURCES PROGRAM ORGANIZATION. 
A breakdown of resources and personnel assigned to the Branch is presented in Appendix II.

Geographic areas of study

Geographic areas of study for 1976 for each of the programs identified in figure 3 are shown on figure 4. Regional geologic studies are shown as shaded areas, and specific sites where topical investigations have been carried out are shown by a coded letter. The letter codes used to identify each program on figures 3 and 4 are used to identify the publications in Appendix III that are the result of studies carried out in that program. Specific projects in each program are similarly identified in Appendix IV with a brief statement as to the objective of each project.

\section{PRINCIPAL FIELDS OF RESEARCH}

\section{Regiona1 Petroleum Geology}

Onshore basin studies

The objective of this program is to conduct petroleum geologic studies of onshore basins in which there is believed to be significant but unrealized petroleum potential. Project work involves integrated surface and subsurface studies. Surface studies are primarily carried out in frontier regions where little or no subsurface data is available, such as the North Slope of Alaska and the Great Basin region of the western United States.

Basin studies in frontier areas contribute significantly to exploration efficiency. Early identification of the regional stratigraphic nuances such as facies changes, and regional extent of source beds and reservoir rocks, help to guide industry explorationists in their search for petroleum accumulations. In addition, early publication of new stratigraphic data and concepts may reduce the need for expensive stratigraphic test wells. Industry cooperates with the Survey by providing samples of rocks and fluids.

Because the Basin Studies program is directed toward regions where high oil and gas potential is believed to exist, projects in the program often become the basis for focused programs on a particular resource or particular geologic unit. New programs that were founded on original onshore Basin Studies projects include the Eastern Gas Shales, the Western Tight Gas Sands, and the Northern Alaska Petroleum Geology programs. Each of these new programs was developed because there was a request for these studies by others in government outside the Branch.

Eastern black shales

Impending shortages of natural gas in several States in the Appalachian basin rekindled interest in the natural gas potential of the Devonian black shale. In 1821 the first gas well in the United States produced gas from the Devonian black shale sequence in the village of Fredonia, Chautauqua County, New York. Since that time many small domestic and semi-commercial wells have produced millions of cubic feet of low-pressure gas from a narrow belt along the south shore of Lake Erie from western New York to north-central Ohio. Elsewhere, many wells drilled into this sequence of black shale from central 

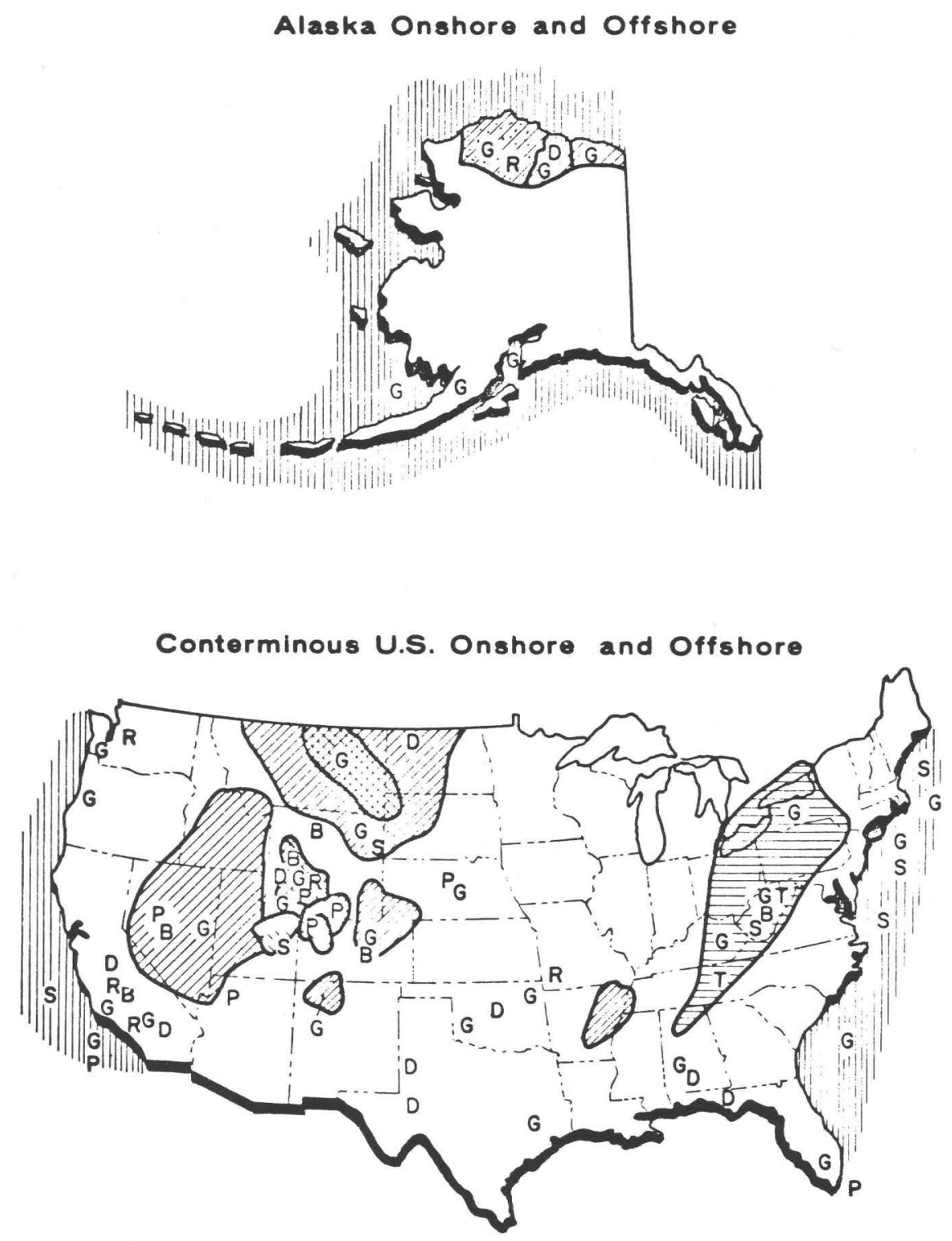

Regional Petroleum Geology

Onshore Basin Studies (OB)

Tisht Cias Sands (TCi)

Easitern Black Shale (ES)

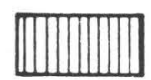

Pacific Arctic and Atlantic Gulf

Petroleum Ceology (PA \& $A C_{t}$ )

Northern Alaska Petroleum Cieology

$(N A)$
Topical Petroleum Geology

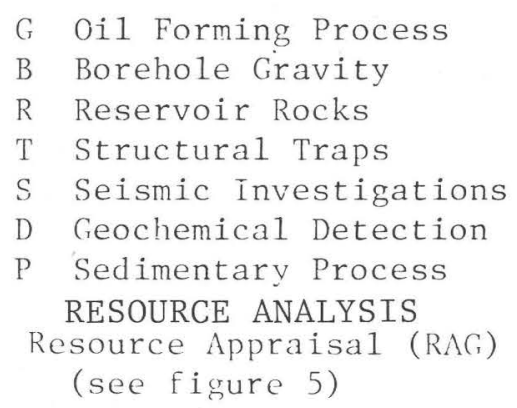

FIGURE 4.--BRANCH OF OIL AND GAS RESOURCES - LOCATION OF REGIONAL PETROLEUM GEOLOGIC STUDIES ANID TOPICAL INVESTIGATIONS. 
New York to central Alabama have encountered shows of gas at many stratigraphic horizons in the shale. Most of these shows have been noncommercial

concentrations. An exception to this generalization is the Big Sandy gas field in southeastern Kentucky and contiguous parts of Virginia and West Virginia. This field has produced over 3 trillion cu ft of gas.

The Branch of Oil and Gas Resources developed a cooperative program with the U.S. Energy Research and Development Administration (ERDA), now the Department of Energy (DOE) to appraise the energy potential of the gasproductive petroliferous black shale of Devonian age in the eastern United States. The program was designed to make an appraisal of the energy resources of the Devonian black shale in the Appalachian basin (fig. 4) by performing a series of stratigraphic, structural, geochemical, and geophysical studies, and by developing a data bank and data retrieval system. The U.S. Geological Survey is coordinating its efforts with other Federal and State agencies, and studies are being conducted by universities and segments of the petroleum industry in order to avoid duplication of effort and unnecessary expense.

In a regional assessment study as extensive as DOE's eastern shale investigations, personnel from many Federal and State agencies, universities, and the petroleum industry will be participating. The U.S. Geological Survey is cooperating with staff from the Morgantown Energy Research Center (MERC) of DOE, the Geological Surveys of Kentucky, Maryland, New York, Ohio, Pennsylvania, Tennessee, Virginia, and West Virginia, personnel from Alfred University, University of Cincinnati, Juniata College, University of Kentucky, and West Virginia University, and representatives from the Columbia Gas Transmission Corporation, the Consolidated Gas Supply Corporation, and other companies in the petroleum industry. The USGS coordinates the geological work being done by the State surveys and universities.

Some parts of the Survey's resource appraisal and characterization program, the stratigraphic studies for example, require essentially continuous effort throughout the five-year life of the program. Other elements of the program, the geochemical studies for example, will depend to a greater extent on samples derived from DOE's drilling and coring.

\section{Western tight gas sands}

With the increased demand and the expectation of increased prices for natural gas, exploration in the Rocky Mountain region and elsewhere is being partially redirected toward "tight gas sands." Preliminary in-place resource estimates for these tight Cretaceous and Tertiary gas sands in the Rocky Mountain region are very large, and estimates by groups such as the Federal Energy Regulatory Commission range as high as 730 trillion cu ft (Tcf) of natural gas. The Resource Appraisal Group did not estimate resources in tight reservoirs in the recently published U.S. Geological Survey Circular 725 because basic geologic knowledge of these resources was considered insufficient to determine limitations on such resources (Miller and others, 1975). "Tight gas sands" are siltstone and sandstone reservoirs predominantly of continental sedimentary origin which contain significant resources of natural gas, but have been subeconomic in the past because of low permeabilities and low gas prices. Low reservoir permeability has resulted in low recovery volumes on an individual well basis, using existing technology. To date, most studies have been directed toward recovery technology. The objective of this study is to characterize these 
tight gas-bearing stratigraphic units and to identify areas which appear to be most favorable geologically for future gas extraction. This geological knowledge can be combined then with geophysical and petrophysical studies, including research on stimulation techniques by DOE, to guide present and future recovery research and to obtain an accurate assessment of recoverable gas resources.

The areas of study are shown in figure 4 and include the Greater Green River, Sand Wash, Uinta, and Piceance basins and the northern Great Plains. The program is divided into two phases: (1) a one-year reconnaissance phase which commenced October 1, 1976, which includes computer processing of well information, core processing and study, construction of regional cross section networks using borehole logs and outcrop sections, petrography, and compilation of regional stratigraphic data; and (2) a four-year comprehensive geological characterization and resource assessment phase.

It is important to note that a major long-range effort is required to characterize these resources. Although these units have been penetrated by drilling and the existence of free gas established, efforts to develop these resources have not been successful. As a result, little development work has been done and the resource estimates that are now available are those based on extrapolations of data from widely scattered wells. In that sense exploration for accumulations of gas in tight sands is at an early stage and there is a low level of understanding of the geologic and engineering characteristics of these reservoirs. However, because of the implied magnitude of the resource potential of tight sands, and its importance to the national energy supply picture, we must develop the data from which reliable estimates of the magnitude of this resource and the cost of its availability can be determined.

Northern Alaska petroleum geology

With the discovery in 1968 of the northern Alaska Prudhoe Bay field, the largest in North America, the onshore area north of the Brooks Range became a major petroleum province. The northern Alaska area is of special interest to the U.S. Government because the Prudhoe Bay area is bounded on the west by National Petroleum Reserve Alaska (NPR-A) and on the east by the Arctic Wildlife Range.

As of June 1977, Naval Petroleum Reserve No. 4 became National Petroleum Reserve-Alaska (NPR-A), and the responsibility for its petroleum assessment is with the Department of the Interior. Within the Department, the Geological Survey has the responsibility for assessing and exploring the mineral potential of NPR-A, and within the Survey, a new office (ONPRA) has been formed to direct these efforts. ONPRA has contracted with the Branch of Oil and Gas Resources to expand its studies in northern Alaska to assist them in the petroleum evaluation of NPR-A. In response to this need the Northern Alaska Petroleum Geology program was formed in December of 1976.

Although the program will focus mainly on NPR-A it will not be limited to that region alone. Important surface and subsurface petroleum geologic studies will continue in the Prudhoe Bay and Arctic Wildlife Range areas.

The studies being conducted in NPR-A and on the north slope are an evaluation of petroleum source rocks, and evaluations of lower Cretaceous sandstones and 
Mississippan carbonates as petroleum reservoirs. These studies will be made on both outcrop and well samples. The results of these studies will be needed for a detailed resource appraisal of the petroleum resources in NPR-A and Northern Alaska which is targeted for completion in 1980.

\section{Continental margin petroleum resources}

The small group of scientists conducting this work are located in Seattle, Washington. The work is funded, only in part, by the Branch of $0 i 1$ and Gas Resources; therefore, the specific research, expenditures and personnel do not appear in the Appendix or in figures summarizing Branch activities and allocations.

The ultimate objective of this program is aimed at the systematic characterization of the geologic framework of the U.S. continental margins, including deep water regions of the rises and borderlands. The resulting characterization should serve to refine present assessments of offshore petroleum resources. The configuration of the base of the sedimentary formations is being shown by means of structure contour and other maps at regional scales $(1: 500,000$ and $1: 2,500,000)$. Because geophysical interpretations form a large part of the basis for these constructions, underlying, nonpetroliferous "basement" rocks and overlying diverse sedimentary strata are described in terms of geophysical characteristics and contrasts (compressional seismic velocities, magnetic susceptibilities and densities). Where outcrops, we11s, or regional extrapolations from onshore subsurface data provide control, the rocks are mapped and also described in terms of petrology, age, or provincial kinships. Problematical transitional relationships between sedimentary rocks and weakly but regionally metamorphosed sedimentary units require research to define combined geophysical-petrological criteria for selection and identification of the metamorphic boundary. These criteria must also be applicable in defining petroleum source- and reservoir-rock characteristics. Unconventional uses of well logs, gravity data, core data, and refraction and reflection (CDP) velocity data are being investigated, together with novel and modified geophysical approaches to petroleum resource analysis. Complementary regional maps of gravity anomalies, geothermal characteristics, sedimentary rock isopachs and lithofacies and sedimentary rock velocities are being compiled or constructed as feasible where needed. Criteria applicable to offshore basins are being established from well explored onshore basins, but early emphasis is being placed on offshore frontier and deep water regions. Emphasis throughout is on geological and geophysical basin characterization needed particularly in petroleum resource analysis.

No comprehensive, systematically constructed model of the geologic framework of the U.S. continental margin is publicly available. As one consequence, the volume of sedimentary rock covering much of the continental margins is poorly known in many regions and virtually unknown in most deep water regions. Furthermore, whether some mildly "metamorphosed" (zeolite facies) sedimentary rocks should be regarded as metamorphic "basement rock" devoid of economic petroleum resources, or as sedimentary rocks from which commercial hydrocarbons are derivable or in which commercial reservoirs might be found is not known. This program is designed to help provide better public knowledge of continental margin sedimentary basin geometry and evolution and more accurate knowledge of basement rock characteristics. 


\section{0i1 forming processes}

Better understanding of the processes by which petroleum and natural gas are generated and migrate can aid in the appraisal of these resources and improve the efficiency of petroleum exploration. A key part of this program is the recognition and evaluation of petroleum source rocks--those rocks which have generated hydrocarbons. The program is proceeding along four concurrent lines:

1) the development of improved methods for the chemical analysis and characterization of sedimentary organic substances;

2) studies of the evolution of petroleum under different geological circumstances which will permit the isolation and evaluation of critical geochemical variables such as organic source material, burial history (time-temperature effects), and catalytic effects, from which one can develop principles which can be applied in frontier areas;

3) formulation of a unified hypothesis for the origin, migration, and accumulation of petroleum, and demonstration of the compatibility of this hypothesis with petroleum geology;

4) development of the geochemical aspects of basin or regional petroleum geology analysis and resource appraisal by providing geochemical measurements and interpretation.

$\underline{\text { Sedimentary processes and reservoir rocks }}$

Resource assessment and appraisal depend in large measure on the ability to accurately identify different sedimentary environments in the subsurface, and to predict the reservoir potential of both carbonate and clastic rocks in various depositional settings. This assessment and appraisal is further dependent on the fact that deep burial of rock units in sedimentary basins causes chemical and physical alterations related to temperature and pressure and pore fluid changes, which influence the original rock reservoir properties of porosity and permeability.

The objectives of this program are (1) to conduct basic studies of the processes which alter or control the characteristics of reservoir rocks; to study specific modern and ancient sedimentary environments in order to develop principles for predicting reservoir quality; and (3) to develop principles for determining or identifying sedimentary environments in ancient rocks.

Studies are being conducted to improve our ability to predict chemical and physical changes in different rock types as a function of their mineralogy and burial history. In addition investigations comparing modern and ancient sedimentary environments are being conducted to determine both the impact of burial diagenesis and methods for recognizing sedimentary environments in ancient rocks. Flume studies are also being carried out to determine criteria to interpret sedimentary environments in ancient rocks. Our ability to evaluate and assess petroleum resources in many frontier areas and especially in offshore areas depends to large extent on our ability to predict the quality and quantity of good reservoirs on the basis of depositional environments and burial history. 
Nearly all oil and gas deposits are related in some way to the structural subsurface configuration of petroleum-bearing strata. In similar geologic settings, analogous patterns of structural deformation can be recognized, and such similarities can be utilized in petroleum exploration provided the tectonic principles and resultant patterns of deformation are understood. The structural patterns and expected position of potential traps for oil and gas thus become more predictable. In addition, structural processes alter subsurface rock properties, either improving permeability through fracturing, or reducing permeability through grain-crushing, compaction, pressure-solution, and so on. Scale of the studies range from regional to detailed investigations of local areas involved in imbricate thrust plates or basin-margin uplifts and faults.

Studies in this program are being applied to problems in the evaluation of subsurface fracture patterns in the Eastern Black Shale program, and also have an important bearing on resource assessment problems in the Overthrust Belt of Wyoming and Montana, and in the Brooks Range Foothills province of Alaska.

\section{Stratigraphic-Seismic}

The Stratigraphic-Seismic Program has two objectives: 1) to carry out original, creative, advanced research in seismic exploration for energy minerals, particularly stratigraphic traps for oil and gas, and 2) to provide needed geophysical-technical support for U.S. Geological Survey groups, especially to those in the offshore resource assessment investigations working on oil and gas programs. During 1976 about 70 percent of the program effort has been in the technical support of these activities; however, most of this effort has had beneficial carry-over to the research work.

Because many of the easier-to-find structural traps (anticlines, domes, fault closures) in the United States have already been located, considerable quantities of the future onshore domestic oil and gas discoveries will probably be in stratigraphic traps. There are three geologic keys to discovery of stratigraphic traps: 1) detailed knowledge of basin stratigraphy, depositional patterns, and hydrocarbon generation; 2) accurate measurement of reservoirs and seals utilizing modern borehole geophysical tools; and 3) use of seismic records to identify potential stratigraphic traps prior to drilling. A multidisciplinary team of geophysicists, computer specialists, and stratigraphers is interrelating these three geologic keys. The result will be the development and publication of new improved exploration techniques applicable by all, but particularly by independent oil operators who now dominate onshore exploration and who will be the principal future explorers for onshore stratigraphic traps.

\section{Geochemical detection}

Recent investigations in this program into these kinds of surface and near-surface manifestations of subsurface oil and gas occurrences suggests a potential for detection of petroleum by cost-effective airborne and satellite photographic geophysical means. Low molecular-weight hydrocarbons seeping from buried accumulations of petroleum commonly are chemically or biochemically oxidized near the surface. When seepage is long-continued, the resulting carbon dioxide reacts with calcium ions, and sometimes magnesium ions dissolved in ground water, to produce isotopically distinctive pore-filling carbonate 
cements in otherwise porous surface rocks. Distinctive trace elements are also incorporated. Localized reducing conditions resulting from the upward passage of hydrocarbons and (or) their associated compounds through surface rocks tends to reduce ferric iron minerals and dissolve and remove the more soluble ferrous iron, commonly causing a discoloration. This color change in the surface rocks may be subtle to marked, depending in general upon the efficacy and rapidity of the leakage, and the original color, iron content, and oxidation state of the altered rocks. Other metals are also mobilized and redistributed. These complex alterations in surface rocks are fossil evidence of long-continued seepage, result in areally restricted, inconspicuous to pronounced, changes in the physical properties of otherwise locally physically homogeneous rocks which are correlatable with the subsurface distribution of petroleum.

Remote sensing techniques, if developed, could have an enormous impact on the exploration for hydrocarbons. In addition, satellite imagery might provide strategic information about the location of future world resources.

In addition to the development of remote sensing techniques, investigations are also under way to assess the exploration potential of other direct detection methods such as soil gas analysis for helium which may be seeping from buried hydrocarbon deposits. This method is of particular interest because of its potential application to marine environments.

Borehole gravity meter

The high-precision Borehole Gravity Meter, pioneered by the U.S. Geological Survey, has the capability to: 1) discover overlooked oil and gas zones in existing wells; 2) generate data useful in improving recovery of oil from producing reservoirs; 3) evaluate low quality reservoirs such as fractured shales, tight sands, oil shales, and coal deposits; 4) serve as a proximity indicator for detection of salt domes, pinnacle reefs, or nearby oil and gas deposits; and 5) provide highly accurate measurements of physical properties of rocks for use in seismic modeling. To date, the full potential of borehole gravity is unrealized because of limitations of prototype instruments and resultant lack of utilization by industry.

This program is proceeding along three lines of investigations: 1) miniaturize, develop, and improve the existing equipment to expand its use in modern slim holes; 2) demonstrate utility of the device to industry; and 3 ) relate results of the method to other borehole geophysical logging methods and to the physical properties of sedimentary rocks.

It is believed that borehole gravity logging will become a very important tool in the energy and other mineral industries in the future. As exploration proceeds into lower quality reservoirs (for example, fractured low-permeability or inhomogeneous shale, sandstone, and limestone) evaluation tools will have to become more sophisticated in order to provide the data required for the evaluation of problem reservoirs. Borehole gravity logs have advantages over conventional logging tools because they measure responses from very large rock volumes. Conventional tools commonly investigate rocks only in very close proximity to the well bore.

Certainly, further development of the tool will improve its application to petroleum problems, but the demonstration of its utility will also encourage 
industry to work on its development. In the last two years, one major oil company has begun to use its own borehole gravity logging tool on a routine basis.

\section{Resource Analysis}

\section{$\underline{0 i 1}$ and gas resource data systems}

The objectives of this program are to develop major subsurface petroleum data systems upon which all of our research application studies and resource analyses can be based. The data system is being developed in two phases. The Phase I system is a data base which includes specific data on oil and gas fields or pools throughout the United States. Through a contract with the University of Oklahoma, continuous building and updating of the Petroleum Data System has been achieved. This system contains production, geologic, and engineering data on some 60,000 oil pools in the United States and is available for public use through General Electric's Mark III time-sharing computer. 1 Currently we are digitizing oil and gas field outlines so that the data in this system can be plotted and analyzed geographically. Although this system has been building and improving for several years there is still a need for new and improved data, especially reservoir data, to enhance the utility of the file. Efforts to accomplish this are ongoing in cooperation with an industry group who are composed of major file users.

The Phase II data system includes data on individual wells drilled for the purpose of exploring for or developing oil and gas fields. A commercial computer file, the Well History Control System, containing data for approximately one million wells in the United States, onshore and offshore, was purchased from Petroleum Information Corp., for government use, to fill that need. The well data file format is being expanded to include additional data such as source rock data, rock properties data, and rock and mineral analysis data. Initially this expanded file will be the basis for well data storage and retrieval in the Eastern Black Shales program, the Tight Gas Sand program and the Northern Alaska studies. In time, as additional data is collected from wells, it is hoped that this file will become a basic storage facility for all types of subsurface well data related to not only oil and gas problems, but to subsurface mineral and water resources problems as well.

In order to develop and refine analyses of petroleum potential of United States regions, we must have samples of cores upon which detailed analyses can be performed. To serve this need the Branch, in conjunction with the Division, maintains a core library facility in Denver. This facility collects and prepares core material required by other programs in the Branch, as well as other programs in the Survey. In addition, the library is open to the public and many oil company geologists visit the facility to study cores.

${ }^{1}$ Use of a specific brand name does not necessarily constitute endorsement of the product by the U.S. Geological Survey. 
Cores and drill cuttings recovered from wildcat and development drilling in the United States are vital both to continuing oil and gas exploration, and to the future evaluation of known petroleum reservoirs for improved recovery potential. The disposition of these cores is commonly controlled by State laws which vary widely in their stringency from State to State. Most cores and cuttings, if saved at all, are stored and curated only by the larger oil companies. As space becomes scarce, a large portion of these rock samples are thrown away; thus valuable exploration and exploitation data is lost. Plans are being made to expand the core library project into a nationwide program.

\section{$\underline{\text { Resource appraisal }}$}

The principal objective of the Survey's oil and gas program is to provide reliable and credible estimates of undiscovered oil and gas resources for purposes of National energy planning, international boundary negotiations, management of Federal lands, and input to the O.C.S. Leasing process.

The Oil and Gas Resource Appraisal program has two objectives: (1) to develop and improve oil and gas resource appraisal methods and procedures, and (2) to apply these techniques within the U.S. Geological Survey and to assess the Nation's domestic energy resources and those world energy resources crucial to national energy policy.

In September 1974 the Resource Appraisal Group entered into an agreement with the Federal Energy Administration (FEA) in its legal responsibility to generate an independent appraisal of the undiscovered onshore and offshore oil and gas resources of the United States by June 1975. To accommodate this need, the Resource Appraisal Group accelerated its ongoing efforts to develop sound appraisal methods and procedures that would permit the systematic collection and evaluation of basic data from petroleum provinces throughout the Nation.

A major objective of this study was to provide appraisals in the framework of a dynamic, data-intensive system to be tested and added to in years to come. That objective was achieved in the FEA study by assembling and analyzing on standardized forms, basic geological and engineering data for 102 individual provinces or combinations of provinces, which are considered to have significant petroleum potential. Estimates based on these data were assembled into an appraisal of 15 regions covering the United States and its Outer Continental Shelf to the 200 meter water depth. The results of this study were published by the U.S. Geological Survey as Circular 725 (Miller and others, 1975).

Circular 725 describes in detail the evaluation methods, the data systems, and a series of mathematical and statistical procedures applied to the basic data. Probability distributions and various combinations of subtotals and totals were published for each of the 15 regions. The major emphasis during the appraisal procedures was the geological assessment of petroleum potential. The results are reported in several different categories reflecting the degree of assurance in terms of identified (or known) reserves and undiscovered resources, and the assumptions regarding technological and economic trends.

The estimates published in Circular 725 (based upon a 95-5 percent probability range) for the undiscovered recoverable resources amount to 50-127 billion barrels of crude oil with a mean of 82 billion barrels (current national economic recovery factor of 32 percent); 322-655 trillion cu ft of natural gas 
with a mean of 484 trillion cu ft (current national economic recovery factor of 80 percent); and 11-22 billion barrels of natural gas liquids with a mean of 16 billion barrels. Figure 5 shows the results of this work for different geographic areas of the United States.

The Resource Appraisal Group obtained the assistance of other geologists in the U.S. Geological Survey who have broad experience and expertise in the particular areas of the United States which are either productive or potential future petroleum provinces. Significant contributions to this study were made by over 70 geologists from the Branch of $0 i 1$ and Gas Resources, the Branch of Pacific-Arctic Marine Geology, the Branch of Atlantic-Gulf of Mexico Marine Geology, and the Conservation Division.

The resource appraisal program depends on many other programs for basic data and geological information about the petroleum geology of specific regions. In addition, they must gather and organize data from all public sources to develop the data upon which subjective probablistic numerical estimates of potential resources are developed.

As the energy problems of the Nation increase, the need by government for additional information about undiscovered resources or subeconomic resources also increases. Requests for new resource estimates now include requests for information concerning the probable size and depth of undiscovered resources. Such requests are based on government economist's need for specific estimates to perform cost studiès on future potential petroleum supplies. To respond to these requests we are attempting to develop data at the level of the geologic unit or slice within a basin. These additional refinements require at least an order of magnitude increase in amount of petroleum data and geological information needed over that collected for Circular 725.

\section{INTERACTIONS WITH OTHER GOVERNMENT AGENCY AND RESEARCH ORGANIZATIONS}

The Oil and Gas Resources Investigations program has cooperated with many oil companies' exploration department research laboratories, and universities, in order to acquire samples and needed geologic data for many of its studies. Cooperation of this type usually depends upon the willingness of the cooperating organization to allow information derived from these efforts to be published so that the public and government can benefit from the work. Because petroleum research so often depends on the interaction of individuals from a wide variety of disciplines, visits and discussions with petroleum geoscientists from industry, academia, State geological surveys, and foreign scientists is encouraged. Over and above these kinds of general cooperative efforts, specific cooperative efforts include:

1. Participation in the Geological Survey Wilderness Studies program and provided resource appraisal for the Teton and Bob Marshall wilderness areas.

2. Cooperative work with the Conservation Division of the U.S. Geological Survey in the preparation of Preliminary Environmental Impact Statements for 0.C.S. leasing and in analysis of COST well data.

3. Developed interagency agreements with:

a) DOE, to study eastern gas shales resources.

b) DOE, to study western tight gas sand resources. 

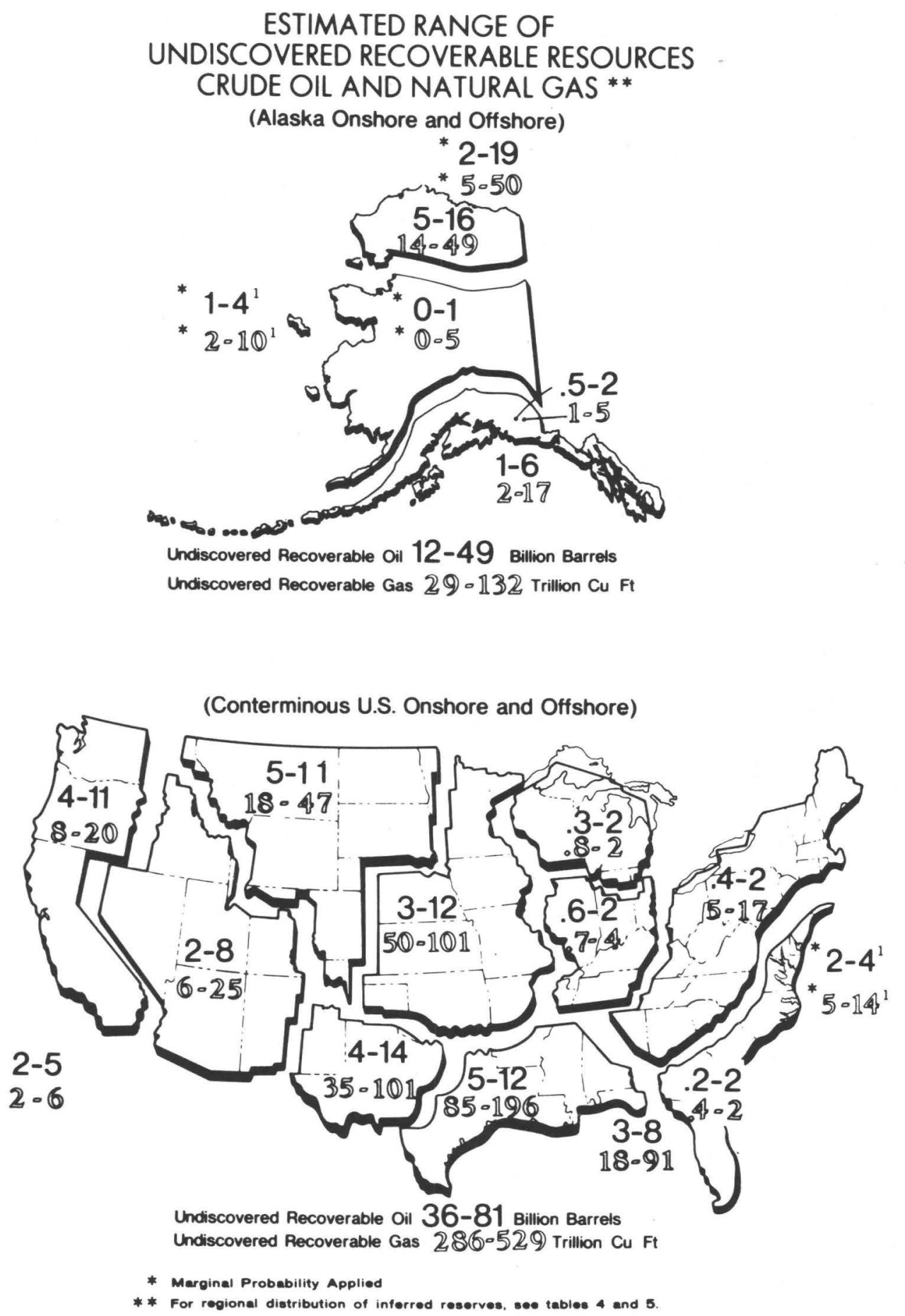

FIGURE 5--Undiscovered recoverable resources of crude oil and natural gas for the United States. Reported as a range of values at 95-5 percent probability in billions of barrels for oil and trillions of cubic feet for gas; from Miller and others (1975).

1 Estimates reported at the 75 and 25 percent probability levels because, in these frontier areas, these levels are judged to be more applicable for some planning purposes. It can also be noted that in frontier areas, lacking discovered indigenous or adjacent recoverable applicable for recorded ranges, the 95-5 percent probability range in the Bering Sea is $0-8$ billion barrels of oil and $0-18$ trillion cubic feet of gas; in the recorded ranges, the Atlantic it is $0-6$ billion barrels of oil and $0-22$ trillion cubic feet of gas. 
c) DOE, to estimate undiscovered oil and gas resources of the United States.

d) DOE, to develop methodology for predicting discovery rates in geologic basins.

e) DOE and DOI, to make study of future United States petroleum supply.

4. Cooperating with Water Resources Division of the U.S. Geological Survey to eestimate aquifer potential of the Madison Limestone in the Powder River Basin using seismic data.

5. Cooperated with and granted funds to the Missouri Geological Survey to study tar sands of Missouri.

6. Granted funds to the Comparative Sedimentology Laboratory at the University of Miami to study modern deposits of shale.

7. Granted funds to the University of Wyoming to study sandstone diagenesis.

8. Work by program specialists on numerous committees in government and for scientific societies, including a recent significant contribution to American Association of Petroleum Geologists Resource Appraisal Committees.

9. Granted funds to California State College to assist in development of the California Well Sample Repository.

Principal users of our expertise were:

1. Contributions of subsurface and petroleum data to Environmental Impact Statements, particularly for western coal basins.

2. Participation in discussions with the U.S. Forest Service concerning oil and gas potential of forest lands.

3. Resource studies on Indian lands for the Bureau of Indian Affairs.

4. Produced for Fish and Wildlife Service a study of the petroleum geology of the Arctic National wildlife range, northern Alaska.

5. Cooperated with A.I.D. (DOS) to provide training for foreign petroleum geoscientists; participated in United States-Russian scientific exchange of petroleum science and technology; provided a Senior Fulbright Fellow to teach seismic methods in Russia for three months; and provided four lecturers to the American Association of Petroleum Geologists Distinguished Lecture Series.

6. Provided to numerous government agencies, results of short studies in response to request for petroleum appraisals or information.

7. Resource appraisals provided for the Preliminary Reports by BLM for the OCS Leasing Program covered various lease areas for offshore Alaska, offshore Atlantic, and one offshore Pacific area.

8. Investigative work for a new petroleum province map of Alaska for the Committee on Statistics of Drilling, American Association of Petroleum Geologists.

\section{ACCOMPLISHMENTS IN 1976}

\section{Regional Petroleum Geology}

\section{Onshore basin studies}

W. W. Mallory has completed an analysis of hydrocarbon-rich shale of Cretaceous age in the central and southern Rocky Mountain region. The scope of 
this investigation includes regional geology, typical fields, reservoir characteristics, and engineering problems associated with petroleum production from fractured-shale reservoirs. A review of newly developing engineering techniques in drilling and well completion indicates that proper completion techniques are necessary to bring in new discoveries successfully. Mallory predicts future discoveries will be made in the following fracture belts: the west margin of the Denver basin, Colorado along the mountain front, (2) the belt of exposed Cretaceous rocks in northwest Colorado, and (3) the steeply dipping rim of the northern part of the San Juan basin, New Mexico and Colorado.

Rocks interpreted as representing widespread Cretaceous(?) and Early Tertiary internal drainage systems are present within an area of more than $8,000 \mathrm{sq}$. $\mathrm{km}$ in east-central Nevada. According to T. D. Fouch, the units may represent at least two periods of closed-basin sedimentation, separated in the area of the Egan Range by an unconformity. Paleontologic work by F. E. May, R. M. Forester, and R. J. Emry, of the Paleontology and Stratigraphy Branch, has provided a time-stratigraphic and paleo-environmental framework for this study.

Reconstruction of lithofacies of the two periods of closed-basin sedimentation indicates that some of the lakes have open-lacustrine beds rich in organic matter. G. E. Claypool has analyzed available core from these potential hydrocarbon source beds. The analysis indicates that the source beds are capable of yielding greater than 16.7 liters of oil per tonne. This study highlights the petroleum potential of some Mesozoic and Tertiary rocks in the Great Basin of east-central Nevada.

Depositional environments of the Upper Cretaceous Eagle Sandstone were studied in northern Montana by D. D. Rice at outcrops along the Missouri River and its tributaries. Several transgressive and regressive sequences were identified. Natural gas from shallow accumulations in the Eagle were identified for the first time as being generated by bacteria shortly after deposition. Gravity-induced faulting is the primary trapping mechanism today; Rice believes, however, that the early traps were caused by facies changes.

E. A. Merewether conducted surface and subsurface stratigraphic investigations of the lower Upper Cretaceous Frontier Formation in the Powder River basin of Wyoming. The Frontier is of marine origin and environments range from offshore to tidal beach. The majority of the sandstone accumulated in a large wave-dominated delta. Isolated recent discoveries of oil in the Frontier Formation of the Powder River basin indicate the presence of a productive stratigraphic trap that may be more than $48 \mathrm{~km}$ long. Present investigations are concerned with correlating unconformities recognized in Frontier outcrops with subsurface well logs. The recognition of hydrocarbon traps related to facies changes and unconformities will improve the success of subsurface exploration.

Well Draw field, a typical Upper Cretaceous stratigraphic trap, was studied in the Powder River basin, Wyoming. According to C. W. Spencer, the trap is an eastward pinchout of shoreface sandstones in the Teapot Sandstone Member of the Mesaverde Formation. This sandstone pinches into marine shale hydrocarbon source beds. Petrographic studies show that the reservoir is a subgraywacke with authigenic chlorite and kaolinite in the pores constricting pore throats and causing low permeability. This research will have impact on primary and secondary recovery at Well Draw field and many similar Cretaceous fields. 
Investigations by C. A. Sandberg, R. C. Gutschick, and W. J. Sando outlined favorable exploration areas for Mississippian oil in western Utah. The stratigraphy of the depositional interface between the 1argely Osagean basinal phosphatic shale member at the bottom of the Deseret Limestone and Woodman Formation on the west and time-equivalent platform carbonate rocks on the east, is being studied in detail. Preliminary geochemical analyses suggest that the phosphatic shale may contain about 3 percent organic carbon, and the interbedded phosphorites about 1 percent organic carbon.

The phosphatic shale basin deposits are present in the northern two-thirds of western Utah. These sediments are believed to be an excellent source for petroleum. Oil would have migrated vertically or laterally updip to the east into stratigraphically higher reservoirs of Late Mississippian age. This migration is interpreted to have occurred during Permian or Mesozoic time. Study of conodont-alteration index (CAI) values by C. A. Sandberg indicates thermal cracking of oil by Tertiary volcanism occurred in much of the shale basin. However, low CAI values (from 1 to 2 ) show optimum oil generation temperatures occur in three areas. One of these areas, in western Utah, encompasses the Burbank Hills and Needle and Confusion Ranges. The other two favorable areas are along the Cordilleran hingeline to the east--near the southern Pavant Range in west-central Utah and near 01d Laketown Canyon, east of the Bear Range in northern Utah.

Eastern black shale

To date, the stratigraphic studies directed by John Roen with the cooperation of personnel from the New York, Pennsylvania, Ohio, West Virginia, and Kentucky Geological Surveys, and Paul Potter, Linda Provo Fulton, and Wayne Pryor of Cincinnati University have developed a series of five north-south and three east-west 1ithostratigraphic cross sections of the Appalachian basin delineating the major conspicuous black shale units as well as a number of local units which may be of some economic importance. In addition to establishing lithostratigraphic control, the group has corroborated their correlations with abundant chronostratigraphic data developed from gamma ray logs, well samples, and surface data from sections in Tennessee, Kentucky, Ohio, and New York.

Anita G. Harris has completed a preliminary analysis of the degree of thermal maturation of the Devonian black shale of the Appalachian basin based on data from outcrop samples in the late spring.

Northern Alaska petroleum geology

Data were compiled for a comprehensive report on the potential petroleum resources of National Petroleum Reserve-Alaska (NPR-A) and a program was developed to assess NPR-A resources. Preliminary analysis of geochemical and well data indicates an oil accumulation similar to the giant field at Prudhoe Bay is not likely to be found in NPR-A. The critical association of truncated Paleozoic and Mesozoic reservoirs immediately beneath Cretaceous source beds occurs at Prudhoe Bay but this condition may only occur in the northeastern part of NPR-A. However, two recent Navy dry holes in northeastern NPR-A decrease the potential of this type of accumulation in that area. 
A preliminary report on the petroleum potential of the Arctic National Wildlife Range was prepared and delivered to the U.S. Fish and Wildlife Service. The study was based upon surface geologic information, geochemical, and gravity data, plus a proprietary aeromagnetic survey furnished by the Fish and Wildife Service. Good source and reservoir beds and probable favorable structural relationships indicate the possibility of significant petroleum accumulations, possibly of the Prudhoe Bay type, in the Wildlife Range area.

A significant report on the petroleum potential of the Lisburne Group carbonates of the Prudhoe Bay region was completed by Ken Bird. Based on study of well logs, samples, and thin sections, the petroleum potential of the Lisburne appears promising because of a favorable combination of reservoir, source rocks, and trapping mechanisms. A continuous high quality dolomite reservoir is present throughout the area and it appears likely that it extends both westward into National Petroleum Reserve Alaska and northward beneath the continental shelf. Evidence from one well along the coast suggests that sandstone may be a significant reservoir in addition to dolomite in the offshore. Lisburne reservoir rocks are in direct contact with documented Cretaceous source rocks east of Prudhoe Bay, and samples have recently been submitted for geochemical analysis to check the possibility of source rocks within the Lisburne and adjacent units south of the Prudhoe Bay area, that is, in more basinward facies. Stratigraphic traps related to unconformities are possible over a wide area: structural traps may be present in the foothills foldbelt of the Brooks Range and along the Barrow arch. Combination traps may be present along the Barrow arch.

\section{Continental margin petroleum resources}

Some specific investigations and accomplishments of this project are:

1. A working hypothesis regarding a statistical relationship among regional gravity anomalies, regional elevation and hydrocarbon contents of large, young sedimentary basins has been investigated in part.

2. The conditions controlling occurrences of the zeolite mineral laumontite in feldspathic and volcanic lithic sandstones and the effects of such diagenetic alteration on reservoir properties have been investigated with important practical results.

3. A preliminary partial gravity map of the central Gulf of Alaska has been compiled.

4. Tentative and preliminary structural and total sediment thickness maps of the continental margin of eastern North America have been compiled at regional scale $(1: 2,500,000)$.

5. The basement rock character and sedimentary rock velocity characteristics are being investigated in the Gulf of Alaska and Kodiak Shelf.

6. A cooperative investigation with NOAA to characterize and analyze a newly discovered gas seep in the offshore Norton Basin of Alaska has been completed.

Topical Petroleum Geology

\section{Oil forming processes}

Since its inception, until the present time, the program acquired, equipped, and staffed a modern laboratory with advanced capabilities in petroleum geochemistry. 
A major achievement was the adaption and development of a rapid and inexpensive technique for source rock evaluation, with sample size requirements in the milligram range. This has resulted in a tenfold increase in the number of samples we can process on a routine basis. A preliminary description and evaluation of this technique has been published by Claypool and Reed (1976), and the technique is being used to process in excess of 2,000 samples/year.

During the year the following studies were completed:

1) A geochemical correlation of crude oils and Cretaceous source rocks in the Denver basin.

2) A geochemical source rock evaluation of the Southern California Continental Borderland and the Southern California cost well.

3) A study illustrating the range of important organic geochemical effects due to burial metamorphism of a uniform, widespread and economically important stratigraphic unit, the Mead Peak and Retort members of the Permian Phosphoria Formation.

4) Analysis of hydrocarbons in barrier-island sands in the northeastern Gulf of Mexico from the standpoint of baseline measurements against which petroleum pollution is detectable. Quantitative and qualitative criteria are established to indicate pollution.

5) A source rock evaluation of selected upper Paleozoic stratigraphic units in the Great Basin and Cordilleran region.

6) A study of the organic geochemical effects of subaerial weathering.

7) Evaluation of the petroleum source rock potential of sediment samples obtained from Deep Sea Drilling Project, Hole 391 (Blake-Bahama Basin) and the Baltimore Canyon COST B-2 well.

8) A geochemical study of the major occurrences of oil and natural gas in the non-marine Tertiary sediments of the Cook Inlet basin, Alaska. Evidence has been developed indicating that the oils probably originated from a sub-unconformity marine Jurrassic section, while the gases are mostly accumulations of biogenic methane generated within the thermally immature Tertiary section.

9) Detailed geochemical analysis samples from a $1,000-\mathrm{m}$ sequence of Pleistocene sediment cored in the Black Sea by Deep Sea Drilling Project, Leg 42B. These samples were obtained to provide a modern geochemical analog for lacustrine sediments in the western United States.

10) A preliminary analyses of samples of rock cuttings from a number of ultra-deep $(>6,100 \mathrm{~m})$ wells, in order to test the hypothesis of a hot, deep origin of petroleum. These results indicate existence of significant concentrations of extractable hydrocarbons at great depths (and presumably temperatures), which generally are thought to result in the destruction of these compounds. If taken at face value, these results are difficult to reconcile with prevailing theories on the origin and evolution of petroleum.

11) Preliminary experimental studies of petroleum solubility in gas-water systems under a range of pressure, temperature, gas composition, and salinity conditions. These data will permit tighter limits to be placed on proposed mechanisms of petroleum migration, and may have an important bearing on future hydrocarbon energy recovered from geothermal waters. 
Sedimentary processes and reservoir rocks

Experimental compaction studies of lime sediment cores by Eugene Shinn showed that, contrary to prevailing geologic thought, lime mud can compact significantly and sedimentary structures resulting from the experiments resemble features common to many ancient limestones. During compaction, megafossils surprisingly were not radically deformed even though an undisturbed sediment core was compressed to one quarter its original volume. Sedimentary structures resembling "horsetails" or insipient stylolites were one important product of the compression experiments. Organic matter was flattened and squeezed horizontally to produce these features which, when seen in ancient limestones, are generally regarded as an incipient form of styolite formation, a product of chemical solution in deeply buried limestone. The work suggests we must reassess the origin and meaning of horsetail-like structures in ancient limestone.

Additionally, the experimental compaction studies suggest a new explanation for the consolidation and conversion of sediment to rock. Loss of initial porosities (usually 60-70 percent) in lime mud may simply result from early compaction before cementation rather than by cementation due to percolating water as generally thought.

Geologists studying carbonate rocks have long sought a means of distinguishing carbonate cements precipitated above the water table from those precipitated below. Two distinct cement types suspected of being related to water table position have been recognized in Pleistocene age limestone in south Florida. The problem is to ascertain whether these cements were related to present or past water tables.

By coring with a unique portable coring machine developed at the Fisher Island Station, R. B. Halley found modern cements above and below the water table on a small Holocene age island. These cements, both of approximately the same age, are distinctly different, yet they are identical to the two kinds of cement present at various levels within the Pleistocene limestone in south Florida. Cements below the water table (fresh water) were found to consist of pointed calcite crystals uniformly distributed around grains. Cements above the water table consist of irregular blocky calcite crystals concentrated at the grain contacts. Recognition of these cements might enable recognition of paleo-water tables in ancient limestone.

The distribution of modern and ancient reefs is controlled by littleunderstood environmental factors. One factor discovered to have a significant influence on the location of 1iving corals in south Florida is unusual temperature extremes. Although the occurrence of temperature extremes is unpredictable, the areas affected by these extremes have a known geologic setting. In the Florida Keys such areas lie opposite or adjacent to tidal passes. Reef-building corals there are often killed, because during periods of unusual weather they are subject to unusually hot or cold waters from Florida Bay and the Gulf of Mexico. More complete understanding of this phenomenon has obvious implications concerning the distribution of possible oil bearing reef deposits in ancient limestones. Studying X-ray photos of tree ring-like banding in corals, J. H. Hudson discovered that certain bands can be correlated with unusually cold winter conditions. The discovery explains the mysterious death of a popular reef area in the Florida Keys. In addition, the work enables one to see temperature effects well back into the 1800 's, before weather data was kept in this area. 
Sedimentation and diagenesis in deep-sea basins is being studied by Harry Cook. Because modern deep-water environments are largely inaccessible to direct observation, this project has also used the approach that ancient environments can help us understand modern environments. In ancient environments we have three-dimensional control on stratigraphic features and can study the evolution of these features and the processes which formed them through geologic time. With the aid of Michael Taylor from the Paleontology and Stratigraphy Branch, studies on a Paleozoic continental margin slope are being studied in central Nevada. This project is providing new insights that can be applied to modern continental slope and deeper water settings. Results to date document that continental slope environments develop by an interplay of erosional and depositional processes. Slope sequences can be composed of a high percentage of slump masses, debris flow deposits and turbidity current deposits of such a small scale (less than 1 meter thick beds) that they can go unidentified on modern continental slopes using conventional surface seismic equipment. Thus it is reasonable to speculate that the smooth, undisturbed nature of some modern slopes as seen on continuous seismic profiles may be, in part, a function of the limited resolving power of much surface seismic equipment. Two implications of this are (1) coarse grained debris flow deposits and turbidite beds may be more common on continental slopes than heretofore recognized--this is important, as under certain conditions these types of deposits may form porous conduits for petroleum migration to shoal water reservoir beds or form potential stratigraphic traps themselves; and (2) petroleum lease sale areas that are judged free from geologic hazards as based on their smooth appearance on seismic records could be undergoing active small-scale sliding, slumping and other mass-wasting processes.

Petrographic work by Wayne Lambert on samples from Umiat Test Well No. 11 (NPR-A) shows that porosity and permeability in the Cretaceous Grandstand Formation, the principal producing formation in the Umiat field, is inversely porportional to the content of phyllite rock fragments. The soft phyllite fragments, and phyllosilicates abraded from them, tend to be squeezed and packed into primary intergranular pores. Porous and permeable sandstone with low phyllite content may have been deposited in high-energy environments that disintegrated the phyllite fragments and winnowed away the debris. The occurrence of petrographically identical phyllite fragments in both high and low phyllite sandstone and changes from high to low phyllite content over relatively short vertical distances ( $8-9 \mathrm{ft}$ ) suggest that provenance is not a major factor affecting phyllite abundance. Porosity and permeability are also affected by grain size; they tend to increase with increasing modal grain size of the sandstone. If reservoir quality in the Grandstand Formation is related to environment of deposition, the search for promising reservoirs can be directed to those areas where high-energy environments may have existed. Recognition of the factors that control reservoir quality in Cretaceous units in NPR-A should allow prediction of areas where rocks with superior reservoir properties are likely to exist and have important bearing on the resource assessment of the region.

Peter Scholle has concluded that the patterns of chalk diagenesis related to maximum depths of burial, pore water chemistry, and primary composition which were initially worked out in the North Sea have been confirmed by work in Gulf Coast, Scotia, Shelf, and Western Interior sections. In general, a major shift in oxygen isotope and $\mathrm{Sr}$ trace element values accompany burial-related 
porosity loss in chalks. However, with a proper understanding of the degree and trend of alteration, one can use a combination of carbon and oxygen isotopes to provide a useful picture of primary depositional environmental conditions Thus, isotopic work has applications for environmental determinations and correlation as well as being an indicator of diagenetic conditions. This work is thus being used both to determine the reservoir potential of chalks under various subsurface conditions but also yields useful information on variations in petroleum source bed potential of chalks and associated units.

Under a grant supervised by Boyd Haley from the Reservoir Rocks program, the Division of Geology and Land Survey of Missouri has studied the potential resources in shallow tar sands in the southwestern portion of the State. As a result of reviewing past data and the drilling of several shallow test holes, they estimated that within the area of study tar sands contained a calculated 287 million barrels of oil. No estimate was made of how much of this was potentia1ly recoverable.

\section{Structura1 traps}

Len Harris reports that through regional structural analysis it can be interpreted that the southern Valley and Ridge and the adjacent parts of the Appalachian Plateau form a single continuous structural sequence:' This sequence can be subdivided from east to west into a low-angle thrust province, middle imbricate zone, and a low-angle thrust faulted foreland. The amount of shortening by thin-skinned deformation in the Valley and Ridge is found to increase progressively southwestward from about $50 \mathrm{~km}$ in north-central Virginia to about $135 \mathrm{~km}$ in Tennessee. Fault patterns in the area indicate that older Alleghenian faults are to the west, so that the westward moving allochthon broke progressively from the foreland on the west to the Blue Ridge on the east.

Hydrocarbon production from the Silurian and part of the Devonian in much of the Appalachian basin appears to be related to regional structural controls. Silurian production is primarily from areas west of the regional decollement developed in the upper part of the Silurian. However, folded and broken Devonian strata above the decollement are productive and are potential sites for primary exploration.

\section{$\underline{\text { Stratigraphic-Seismic }}$}

In July 1976, the program obtained vertical seismic profile data in water wells located in the Powder River Basin, near Lusk and Newcastle, Wyoming. This work was sponsored by Water Resources Division of the Geological Survey, and the measurements will be used for both the Madison Project and the Stratigraphic-Seismic program. We are now attempting to use the data to calculate acoustic parameters of stratigraphic horizons--both water bearing and oil bearing.

A procedure for the computer handling of digitized well log suites has been developed for the Seismic Data System. Analyses of these suites and cross plots of the data may be useful in pinpointing physical rock properties significant to stratigraphic oil accumulation. 
The Program has (a) analyzed, processed and made displays of nine (9) Aocs seismic lines and four (4) more lines will be completed by the end of the calender year; (b) processed and continuing to process seismic profiles from Pacific offshore areas of northern California, northern Oregon, and Alaska; (c) reprocessed and made displays of the seismic lines across the Salt Valley anticline in Utah for the Branch of Special Projects with particular attention given to the delineation of non-salt horizons in a salt diapir; and (d) acquired approximately $160 \mathrm{~km}$ of land seismic data for Water Resource Division, and these tapes, when processed, will constitute the initial surface seismic activity on the Madison Project.

$\underline{\text { Geochemical detection }}$

Detailed examinations of four oil fields were completed in 1976. Comprehensive data sets which support the existence of surface anomalies have now been found over the following oil fields: Bisti, New Mexico; Cement, Davenport, Doyle, Fox-Graham, and Velma, Oklahoma; Garza and Jameson Reef, Texas; and Kettleman Hills, California. A suspected, but untested, petroleumrelated geochemical anomaly at Gunbarrel Hill, Colorado has also been studied. These data support interpretations that indicate that at least three microseepage mechanisms operate. These are (1) effusion of small to large amounts of gaseous and liquid hydrocarbons through relatively thin overburden columns along natural avenues of vertical fluid communications. Such avenues include faults and fractures and through poorly compacted or otherwise inadequate cap rocks, (2) low-molecular-weight hydrocarbons dissolved in water moving vertically through capping shale behaving as semi-permeable membranes. Hydrodynamic pressure or differences in chemical potential on opposite sides of the membranes provides the driving force, and (3) diffusion of gases dissolved in water through cap rocks. All of these processes represent end-member mechanisms. Combinations of these seepage mechanisms also operate and are distinguished on the basis of interpretations of distinctive isotopic and chemical parameters in carbonatecemented surface rocks and in some cases, reservoir fluids. Work is under way to investigate cost effective remote sensing methods to identify these kinds of anomalies as a method of prospecting for petroleum.

Recent work by A. A. Roberts and M. C. Dalziel suggests the utility of a helium survey technique in exploration for geothermal resource areas and oil and gas reservoirs. This technique involves measuring the concentration of the inert gas helium in the soil at a depth of about $1 / 2$ meter. Abnormally high concentrations of helium may be indicative of the buried energy deposit.

Work is completed over a number of oil and/or gas reservoirs. Good correlation is observed between high near-surface helium concentrations and the known production areas of two helium-rich gas fields in Utah. Also, a preliminary survey of the Garza 0il Field in Texas reveals abnormally high concentrations of helium in the soil gas over the whole producing area. Helium surveys also suggest the existence of potential petroleum prospects in the Denver basin, Colorado, the Fort Worth basin in Texas, and a Dutcher prospect near Bixby, 0klahoma. Two of these three prospects have nearly completed wildcat wells drilled into them. During 1976 some initial helium work was also done over the giant Prudhoe Bay field in northern Alaska. The purpose of this work was to test the procedure in an area of permafrost. 
Surveys are also completed over three known geothermal resource areas in the Imperial Valley of California, over the geothermal reservoir at Roosevelt Hot Springs in Utah, over the geothermal anomaly in the East Tintic Mining District of Utah, and over or around several hot springs in Colorado and Wyoming. In each locality a good correlation is observed between the areas of high heat flow or high temperature gradient and the areas of high helium concentration. The known geothermal reservoirs at depths from $305 \mathrm{~m}$ to $1829 \mathrm{~m}$ are all wel1 outlined by the helium anomaly. As a result of this work, numerous private companies have begun testing this relatively inexpensive exploration tool using their own geothermal prospects as research areas.

Borehole gravity

During 1976 the program was able to develop much of the equipment necessary to carry out, in an efficient manner, field borehole gravity surveys. In addition, ten wells were successfully logged with the old borehole gravity meter in spite of a logging accident which disabled the meter for several months. The data from these wells were reduced, as were the data from nine borehole gravity surveys made in 1975. Well logs, core analyses, and production data were acquired to support the analysis of borehole gravity surveys.

Borehole gravity data obtained in a California well penetrating highlyfractured plutonic rocks were evaluated, and low density zones, indicative of intense fracturing, were located behind casing in this well. The effect of the nearby San Andreas fault was also identified in the subsurface gravity data. The superiority of borehole gravity logging over other well logging methods for defining porosity in carbonate rocks was demonstrated in the Madison Limestone of Wyoming. Cretaceous gas sands were delineated through casing in several wells in the Big Horn Basin. Accurate estimates of porosity were made for the poorly-consolidated, heavy-oil sands in the Kern River and Midway-Sunset oil fields, California. All of these results are important in the application of borehole gravity to hydrocarbon exploration and production, and should be beneficial to industry's expanding efforts in this area.

Resource Analysis

\section{Oi1 and gas resource data systems}

During 1976 we were able to complete the purchase of all well data in the Well History Control System. Current well data for all new exploratory wells in the United States are now added to the system on a monthly basis. In addition, work on the development of formats to include all types of subsurface data is in progress. New formats should be prepared and ready for use in late July 1977. In 1976 we began to digitize oil field outlines to expand the utility of the Petroleum Data System. Completion of this project is also estimated for 1977. When this program is completed we will greatly expand our ability to synthesize the geologic data from the Well History Control System with production and engineering data from the Petroleum Data System on a geologic unit basis. This new capability will greatly assist us in bringing together necessary data for resource assessment and appraisal, and enable us to respond more rapidly to the requests for oil and gas resource information.

Since its inception in July 1974, the Physical Properties Data Bank has acquired over $453,000 \mathrm{~kg}$ of cores from holes drilled to evaluate oil and gas, 
uranium/thorium, and oil shale. Industry support of the facility has been excellent and other branches and divisions of the U.S. Geological Survey have availed themselves of this storage and core repository. Cores from over 850 wells have been slabbed with a recently acquired diamond saw. Slabbing permits improved study of cored rock features and reduces volume of space needed to store core. Excess from slabbed cores, not needed for analysis by Survey projects, will be distributed on an equitable basis to universities and research groups.

\section{$\underline{\text { Resource appraisal }}$}

The Resource Appraisal program continued with its basic responsibility of revising and updating the resource agreement for the United States originally published as Circular 725. The areas receiving the highest priorities in 1976 are the offshore continental shelves of the United States, onshore frontier areas, particularly Alaska, and areas with major new exploration activities such as the Overthrust Belt in Wyoming.

A significant contribution was made by RAG, headed by Betty Miller, Program Manager for an Interagency Contract with the Federal Energy Administration (FEA) to provide an investigative study reviewing all finding rate (discovery rate) methodologies, and to develop for the FEA finding rate methods apropos of our previous resource appraisal work on a basin or province approach. These methods, developed for varying stages of exploration effort, were reported along with related pilot study areas, in an interim report submitted to the FEA in 1976. This report is current1y under revision in preparation for publication in 1977.

In 1976, the Resource Appraisal program was committed to two major projects: (1) the Interagency Oil and Gas Supply Project (Department of the Interior) Task I, and (2) continuing the work on updating, revising and expanding the basic domestic resource appraisal work for a new resource appraisal publication as a followup to Circular 725.

The objectives of Task I for the Interagency Project are for the Resource Appraisal Group to provide detailed resource appraisals by geologic horizons and depth intervals, and probable field size distributions for three pilot areas as input to the remaining Task Forces involved in this Interagency Project. The three pilot areas under study that were initiated in December 1976 are: the Permian Basin (west Texas and southeast New Mexico), the Gulf of Mexico, and the mid-Atlantic OCS.

The major objective for the continuing work on domestic resource appraisal will be the publication of a more comprehensive and expanded version of Circular 725. The Resource Appraisal program has made significant progress since the publication of Circular 725 in having established a more uniform and comprehensive system of resource appraisal methods and procedures.

\section{Opportunities for External Participation}

To help attain the objectives of its various programs, the Geological Survey is authorized by Public Law 85-934 to spend funds through grants for the support of scientific research and for other purposes. Grants may be awarded only to colleges and universities, other non-profit organizations, and State 
and local governments. They are based on unsolicited research proposals submitted by investigators who believe that they can contribute to an ongoing scientific program conducted by the Geological Survey. Research proposals may be submitted to the Survey at any time, but some programs will consider only those proposals submitted in response to a public announcement of a project to be carried out partly or exclusively through research grants.

Opportunities for grant-supported research projects related to the oil and gas probram depend on the nature and scope of the proposed work, its importance to the program, and the availability of funds. Proposals that complement, rather than duplicate or overlap, existing or planned Survey-conducted projects on oil and gas resources have a better chance of receiving support. A prospective grantee may discuss his proposal with appropriate staff members in the Branch of Oil and Gas Resources before formally submitting it to the Geological Survey.

Detailed information about the procedures for applying for a research grant are contained in a Geological Survey pamphlet entitled "Grants for scientific research." Copies of this publication may be obtained from any Survey office.

The Geological Survey may award a research contract, as opposed to a grant, to any individual or group, including for-profit organizations, that has the capability to deliver the required product, such as a map, a report, rock or mineral samples, analytical data, or a scientific instrument. A contract usually is awarded in response to a Request for Proposals (RFP), which the Geological Survey issues whenever it requires the services of a private organization. The Survey may send copies of an RFP to known potential contractors, and the RFP also is published in Commerce Business Daily. However, in some circumstances a contract may also be awarded on the basis of unsolicited proposals.

Further information about grants or contracts related to the oil and gas program may be obtained form the Branch of $0 i 1$ and Gas Resources, U.S. Geological Survey, Denver Federal Center, Denver, Colorado 80225. 

ORGANIZATION OF THE U.S. GEOLOGICAL SURVEY, GEOLOGIC DIVISION AND THE OFFICE OF ENERGY RESOURCES ORGANIZATION OF THE OFFICE OF GEOLOGICAL SURVEY

\begin{tabular}{|l|}
\hline OFFICE OF THE DIRECTOR \\
\hline DIRECTOR \\
ASSOCIATE DIRECTOR \\
SENIOR SCIENTIST \\
CHIEF GEOGRAPHER \\
CHIEF, OFFICE OF INFORMATION \\
\hline
\end{tabular}

EARTH RESOURCES OBSERVATION SYSTEMS (EROS) PROGRAM

(1)

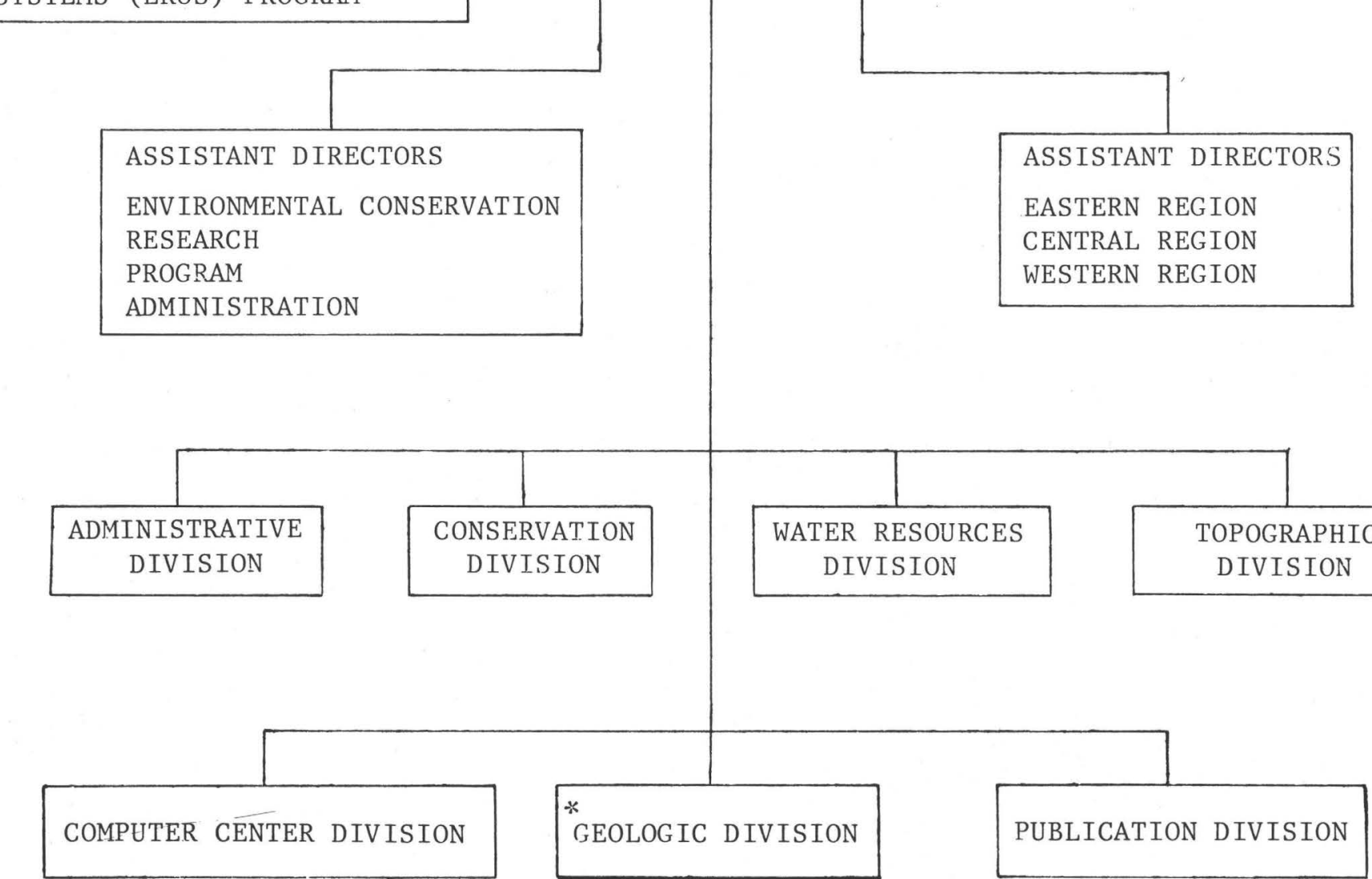




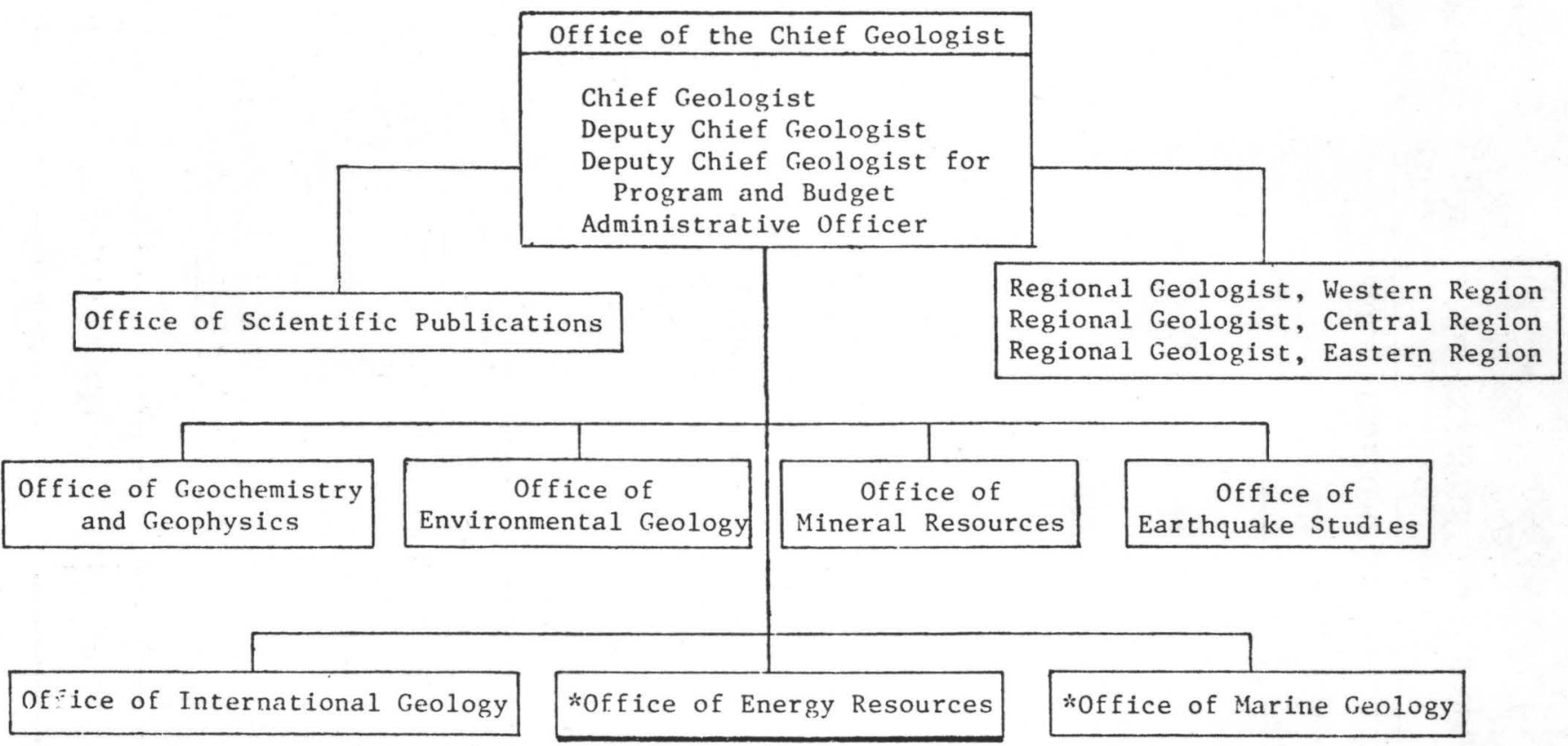

ORCANIZATION OF THE OFFICE OF ENERGY RESOURCES

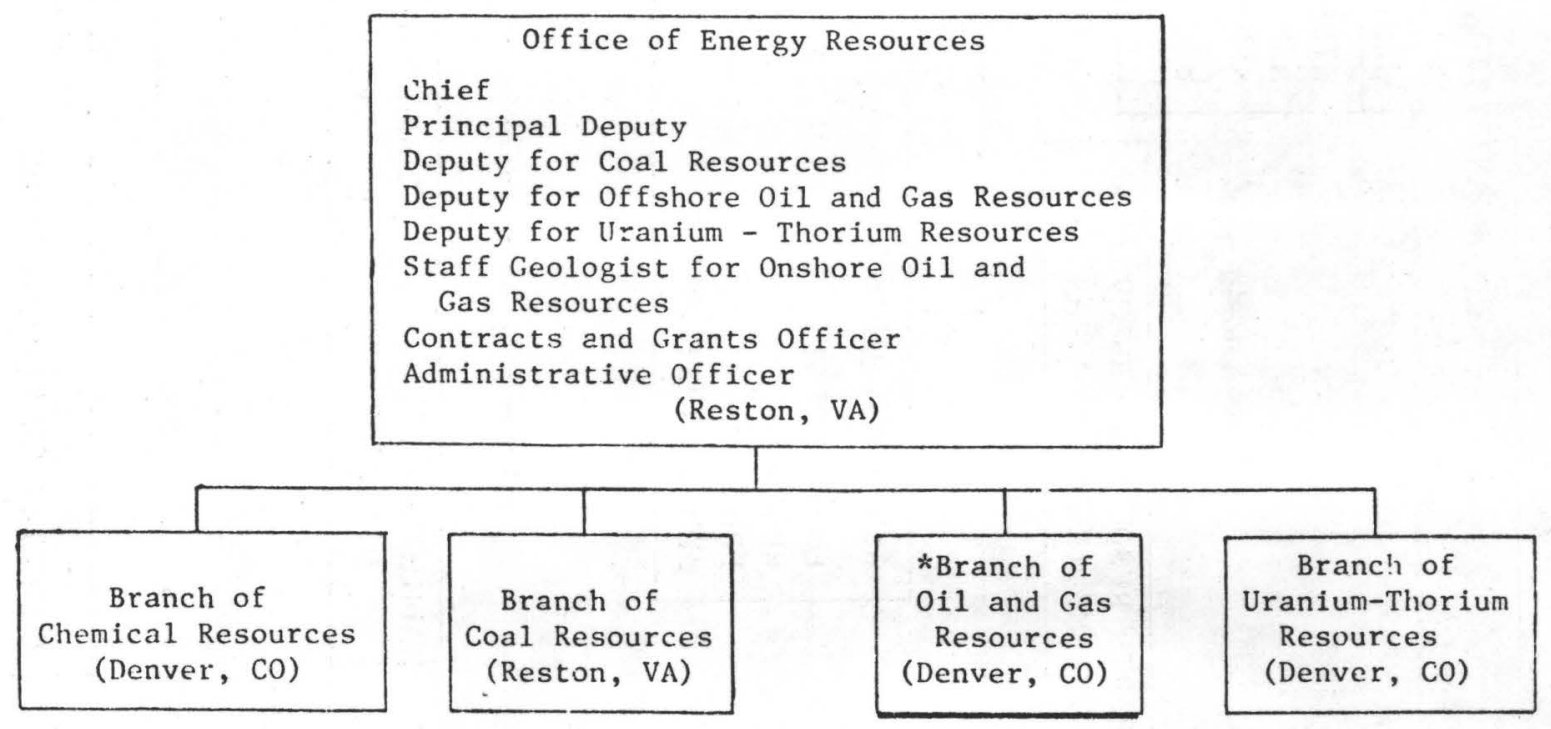




\section{APPENDIX ||}

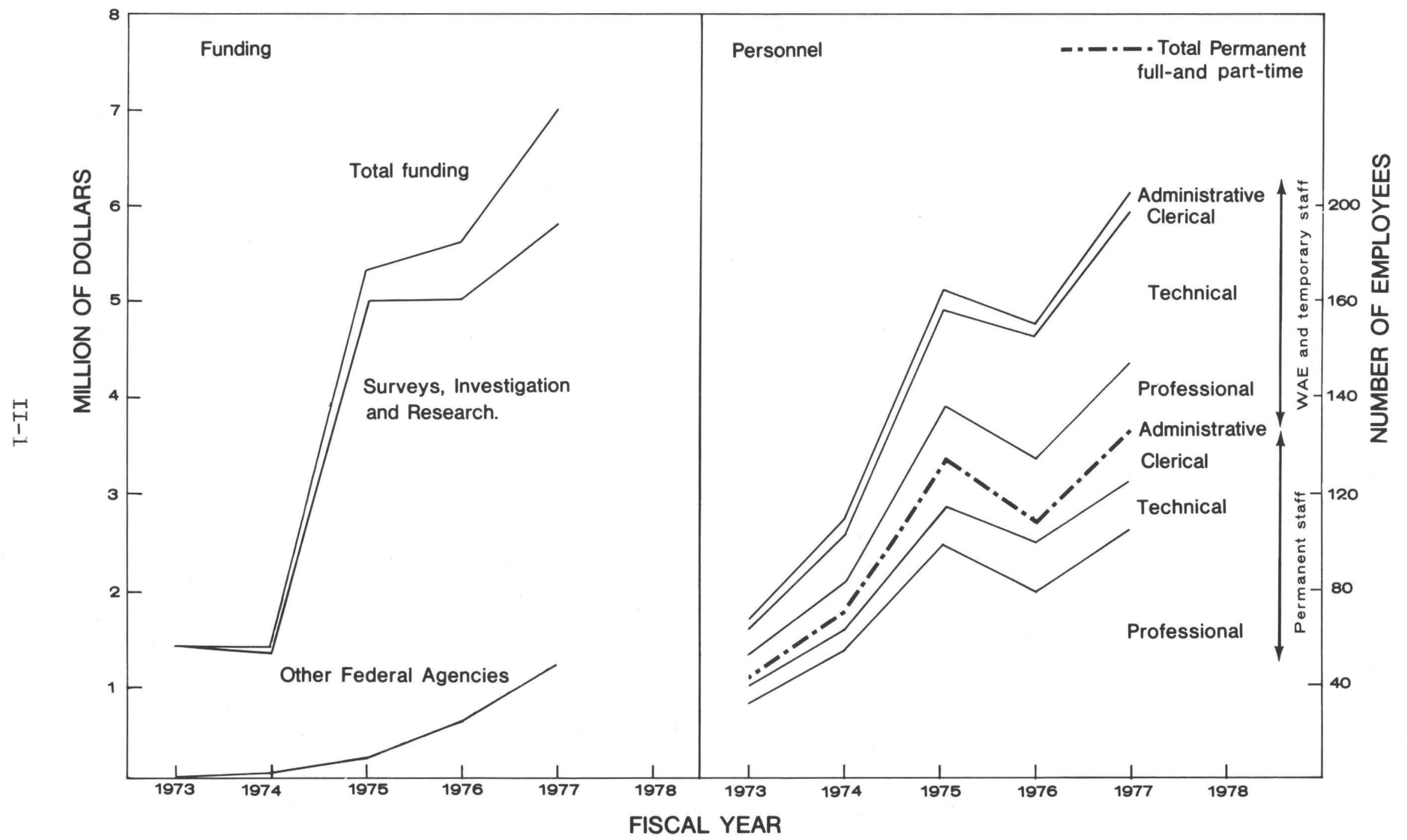




\section{Program Elements}

Eastern Black Shale

Resource Appraisal

Oil Forming Processes

Seismic Stratigraphic Studies

Data Systems

Onshore Basin Studies

Tight Gas Sands

Northern Alaska

$\stackrel{1}{N}$

\section{Geochemical Detection}

Borehole Gravity

Reservoir Rocks and

Sedimentary Processes

Structural Traps

Pacific-Arctic OCS

Atlantic-Gulf OCS

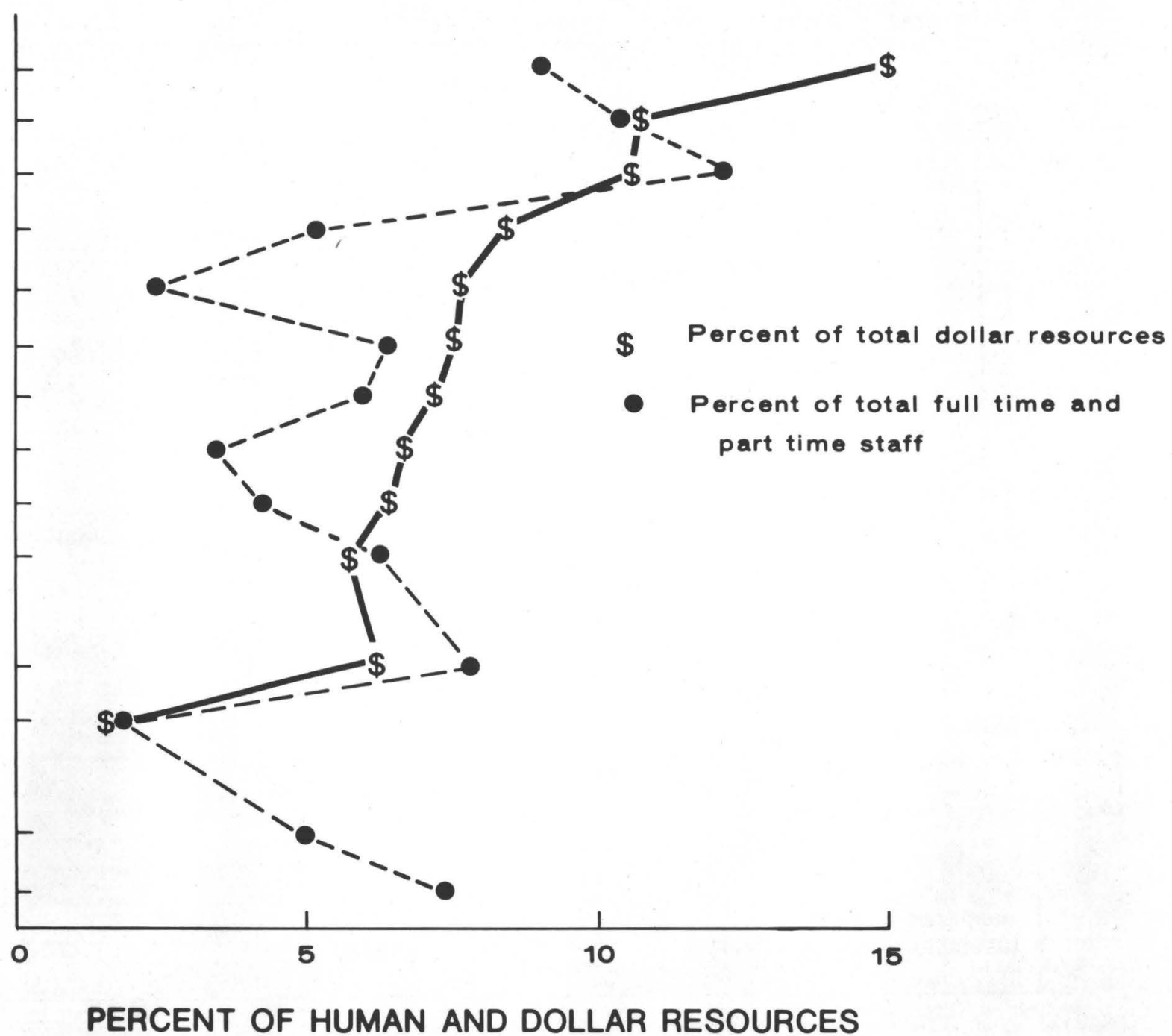

Application of Resources by program 


\section{APPENDIX III}

\section{List of Recent Publications and Reports}

Regional Petroleum Geology

Onshore Basin Studies (OB)

Tight Gas Sands (TG)

Eastern Black Shale (ES)

Pacific Arctic Petroleum Geology (PA)

Atlantic Gulf Petroleum Geology (AG)

Northern Alaska Petroleum Geology (NA)
Topical Petroleum Geology

oil Forming Process (G)

Borehole Gravity (B)

Reservoir Rocks (R)

Structural Traps (T)

Seismic Investigations (S)

Geochemical Detection (D)

Sedimentary Process (P)

\section{Resource Analysis \\ Resource Appraisal (RAG) \\ Oil and Gas Data Systems (OGS)}

PA Adkison, W. L., Kelley, J. S., and Newman, K. R., 1975, Lithology and palynology of Tertiary rocks exposed near Capps Glacier and along Chuitna River, Tyonek quadrangle, southern Alaska: U.S. Geol. Survey Open-File Rept. 75-21.

PA 1975, Lithology and palynology of the Beluga and Sterling Formations exposed near Homer, Kenai Peninsula, Alaska: U.S. Geol. Survey Open-File Rept. 75-383, 240 p.

Ahlbrandt, T. S., 1975, Comparison of textures and structures to distinguish eolian environments, Killpecker dune field, Wyoming: Mountain Geol. v. 12, p. 61-73.

Ahlbrandt, T. S., and Andrews, Sarah, 1977, Preliminary geologic studies of cold climate dunes in North Park, Jackson County, Colorado: U.S. Geo1. Survey Open-File Rept. 77-145.

P. Ahlbrandt, T. S., and Fryberger, S. G., 1976, Structures and textures of eolian deposits in the Nebraska sand hills, U.S.A.: 25th Internat. Geol. Cong., Sydney, Australia, Abstracts, v. 3, p. 829. U.S. Geol. Survey Prof. Paper (in press). 1978, Preliminary results, organic geochemical investigations of Black Sea sediments--Deep Sea Drilling Project Leg 42B, Initial Report of the Deep Sea Drilling Project, Volume XLIV: Washington, Govt. Printing Office (in press).

NA Armstrong, A. K., and Bird, K. J., 1976, Carboniferous environments of deposition and facies, Arctic Alaska, in Recent ancient sedimentary environments in Alaska: Alaska Geological Society Symposium, Proc., April 1975, Anchorage, Alaska, p. Al-Al6.

PA Arnal, R. E., 1976, Miocene paleobathymetric changes of the Santa RosaCortes ridge area, California continental borderland, in Howell, D. G., ed., Aspects of the geologic history of the California Continental Borderland: Am. Assoc. Petroleum Geologists, Pacific Sec., Misc. Pub1. 24, p. 60-79. 
PA Arna1, R. E., and Vedder, J. G., 1976, Changes in Miocene of the California continental borderland north of 32 (abs.): Am. Assoc. Petroleum Geologists Bull., v. 60, no. 4, p. 646.

PA 1976, Late Miocene paleobathymetry of the California continental borderland north of $32^{\circ}$ : AAPG/SEPM, Pacific Section, San Francisco, April 1976, Symposium Volume, p. 1-8.

Balch, A. H., Lee, M. W., and Ryder, R. T., 1977, Application of vertical seismic profiles to stratigraphic exploration problems, Powder River Basin, Wyoming (abs.): Am. Assoc. Petroleum Geologists Bull., v. 61, no. 8, p. 1371.

1977, Use of vertical seismic profiles in stratigraphic exploration (abs.): 30th Annual Midwestern Meeting, Society of Exploration Geophysicists, Apri1 7, 1977.

Balch, A. H., Ruskey, F., Lepper, M. C., and Peterson, S. D., 1976, Use of the seismic reflection method in coal seam mapping (abs.): Geophysics, v. 41 , no. 2 , p. 340 .

Barnes, D. F., Kososki, B. A., Mayfield, C. F., Ruppe1, B. D., Robbins, S. L., and Tailleur, I. L., 1976, Gravity data from Mt. Michelson, Flaxman Island, demarcation point, and Barter Island quadrangles, Alaska: U.S. Geol. Survey Open-File Rept. 76-258, 4 pls.

Bayer, K. C., Mattick, R. E., Plafker, G., and Bruns, T. R., 1978, Refraction studies between Icy Bay and Kayak Island, eastern Gulf of Alaska: U.S. Geol. Survey Jour. Research (in press).

Behrendt, J. C., Schlee, J. S., Grow, J. A., Dillon, W. P., and Mattick, R. E., 1975, Multichannel seismic, aeromagnetic and gravity investigations of the Atlantic margin of the United States (abs.): Ancient Plate Margins Interdisciplinary Symposia Instit. Francais du Petrole, Mal Maison, France.

PA Behrendt, J. C., Schlee, J. S., Grow, J. A., Dillon, W. P., Mattick, R. E. and Fall, J. P., 1975, Multichannel seismic aeromagnetic, and gravity investigations of the Atlantic Margin of the United States (abs.): Soc. Explor. Geophysicists Abs, with Programs, 45th Ann. Mtg., Denver, 1975.

Beyer, L. A., 1976, The interpretation of borehole gravity surveys (abs.): Program of the 46th Annual International Meeting of the Society of Exploration Geophysicists, Houston, October 24-28, 1976, p. 49-50.

Beyer, L. A., Brune, R. H., and Schmoker, J. W., 1975, Applications of borehole gravity studies in exploration for oil and gas: presented at 50th Annual Meeting, Pacific Section AAPG/SEG/SEPM, Long Beach, Apri1 23-26, 1975. 
NA Bird, K. J., 1976, Environmental and time significance of 1ocal guide fossils, Lisburne Group, northeast Alaska (abs.): Am. Assoc. Petroleum Geologists Bul1., v. 60, no. 12, p. 2175.

NA 1976, Petroleum potential of the Lisburne Group, eastern Arctic Slope, Alaska: U.S. Geo1. Survey Circ. 733, p. 26.

NA 1976, Reservoir study of Lisburne Group and structural and stratigraphic studies in the eastern foothills of the Brooks Range (North Slope Petroleum Program): U.S. Geol. Survey Circ. 732, p. 36.

Bird, K. J., and Jordan, C. F., 1976, The Lisburne Group--potential major objective of the eastern Arctic Slope, Alaska (abs.): Am. Assoc. Petroleum Geologists Bul1., v. 60, no. 4, p. 649-650. the Arctic Slope, Alaska: U.S. Geol. Survey Open-File Rept. 76-786, $58 \mathrm{p}$.

1977, Lisburne Group (Mississippian and Pennsylvanian), potential major hydrocarbon objective of the Arctic Slope, Alaska: Am. Assoc. Petroleum Geologists Bul1., v. 61, no. 9, p. 1493-1512.

1977, The petroleum potential of the Lisburne Group, eastern Arctic Slope, Alaska: Oil and Gas Jour., April 18, 1977, p. 90-94.

Blake, M. C., Campbe11, R. A., Dibblee, T. W., Jr., Junger, Arne, Howe11, D. G., Nilsen, T. H., Normark, W. R., Silver, E. A., Taylor J. C., and Vedder, J. G., 1976, Neogene basin formation and hydrocarbon accumulation related to San Andreas fault system and plate tectonics in western California: Continental Margin Symposium, Nat'1 Mtg. AAPG, New Orleans, p. 43-44.

PA

Bruns, Terry, and Plafker, George, 1975, Preliminary results of a 1975 geophysical study of the offshore Gulf of Alaska Tertiary province (abs.): AAPG/SEG/SEPM, Pacific Section, Long Beach, April 1975.

OB Carter, R. D., 1975, Naval Petroleum Reserve No. 1--a geologic summary of the Elk Hills Field, California: AAPG Annual Meetings Abstracts, v. 2 , p. 10 .

NA Carter, R. D., Denman, J. M., and Pierpoint, J. G., 1975, Geologica1 literature on the North Slope of Alaska, 1969-1974: U.S. Geol. Survey Open-File Rept. 75-384.

G Cecil, C. B., Stanton, R. W., and Robbins, E. I., 1977, Geologic factors controlling coalification and hydrocarbon maturation (abs.): Am. Assoc. Petroleum Geologists Bul1., v. 61, no. 5, p. 775.

PA Clark, S. H., Howe11, D. G., and Nilsen, T. H., 1975, Paleogene geography of California, in Future Energy Horizons of the Pacific Coast: Paleogene Symposium and Selected Technical Papers: AAPG-SEG-SEPM, Pacific Section p. 121-154. 
Claypoo1, G. E., 1975, Bacterial methane and natural gas deposits: Geol. Soc. America Abs. with Programs, v. 7, no. 7, p. 1029-1030.

Claypoo1, G. E., and Baysinger, J. P., 1977, Thermal analysis/pyrolysis of Cretaceous Sapropels-DSDP Leg 44, Site 391, Blake-Bahama Basin, in Initial Reports of the Deep Sea Drilling Project, Vol. XLIV: Washington, U.S. Govt. Printing Office (in press). geochemistry, incipient metamorphism and oil generation in black shale members of the Permian Phosphoria Formation, Western Interior United States: Am. Assoc. Petroleum Geologists Bu11., v. 62, no. 1, p. $98-120$.

Claypool, G. E., Lubeck, C. M., Baysinger, J. P., and Ging, T. G., 1977, Organic geochemistry, in P. A. Scholle, ed., Geological Studies on the COST No. B-2 Well, U.S. mid-Atlantic Outer Continental Shelf Area: U.S. Geo1. Survey Circ. 750, pp. 46-59.

Claypoo1, G. E., Lubeck, C. M., Patterson, J. M., and Baysinger, J. P., 1976, Organic geochemical analyses of cores, Chapter in Paul, R. G., and others, Geological and operational summary, Southern California Deep Stratigraphic Test OCS-CAL 75-70 No. 1, Cortes Bank Area Offshore Southern California: U.S. Geol. Survey Open-File Rept. 76-232.

Claypoo1, G. E., and Reed, P. R., 1976, Thermal analysis technique for source rock evaluation--quantitative estimate of organic richness and effects of 1ithologic variation: Am. Assoc. Petroleum Geologists Bu11., v. 60, no. 4, p. 608-612.

Clayton, Jerry L., and Swetland, Paul J., 1976, Subaerial weathering of sedimentary organic matter: Geol. Soc. America Abs. with Programs, v. 8 , no. 6 , p. 815 .

OB Cobban, W. A., Erdmann, C., Lemke, R. W., and Maughan, E. K., 1976, Type sections and stratigraphy of the members of the Blackleaf and Marias River Formation of the Sweetgrass Arch, Montana: U.S. Geo1. Survey Prof. Paper 974, 66 p.

P Cook, H. E., 1975, North American stratigraphic principles as applied to deep-sea sediments: Am. Assoc. Petroleum Geologists Bull., v. 59, no. 5, p. 817-837.

1976, Sedimentary stratigraphic framework along the Line Islands, equatorial Pacific, in Schlanger, S. 0., and others, Initial reports of the Deep Sea Drilling Project: Washington, Govt. Printing Office, v. 33, p. $849-853$.

Cook, H. E., and Enos, P., eds., 1977, Deep-water carbonate environments: Soc. Econ. Paleontologists and Mineralogists Spec. Pub. No. 25, 336 p.

1977, Deep-water carbonate environments--an introduction, in Cook, H. E., and Enos, P., eds., Deep-water carbonate environments: Soc. Econ. Paleontologists and Mineralogists Spec. Pub. No. 25, p. 1-3. 
Cook, H. E., Jenkyns, H. C., Kelts, K. R., 1976, Redeposited sediments along the Line Islands, equatorial Pacific, in Schlanger, S. 0., and others, Initial reports of the Deep Sea Driliing Project, Volume 33: Washington, Govt. Printing Office, p. 837-847.

Cook, H. E., Johnson, P. D., Matti, J. C., and Zemme1s, I., 1975, Methods of sample preparation and X-ray diffraction data analysis, X-ray mineralogy laboratory, Deep Sea Drilling Project, University of California, Riverside, in Hays and others, 1975, Initial Reports of the Deep Sea Drilling Project: Washington, Govt. Printing Office, p. 999-1007.

Cook, H. E., and Taylor, M. E., 1975, Basinal environments and trilobites of the Cambrian-Ordovician Hales Limestone in central Nevada (abs.): AAPG Annual Meeting Abstracts, v. 2, p. 13. 1975, Slope environments of a Cambrian-Ordovician continenta1 margin, western United States: Geol. Soc. America Abs. with Programs, v. 7, no. 7, p. 1037. 1975, Early Paleozoic continental margin sedimentation, trilobite biofacies, and the thermocline, western United States: Geology, v. 3, no. 10, p. 559-562. 1977, Comparison of continental slope and shelf environments in the Upper Cambrian and Lowest Ordovician of Nevada, in Cook, H. E., and Enos, P., eds., Deep-water carbonate environments: Soc. Econ. Paleontologists and Mineralogists Spec. Pub. No. 25, p. 51-81.

P Cook, H. E., and Zemmels, I., 1975, X-ray mineralogy data, AustraliaAntarctic Region, Leg 28, Deep Sea Drilling Project, in Hays and others, 1975 Initial Reports of the Deep Sea Drilling Project, Volume 28: Washington, Govt. Printing Office, p. 981-998.

Cook, H. E., and Zemmels, I., 1975, X-ray mineralogy data, Far Western Pacific, Leg 31, Deep Sea Drilling Project, in Karig and others, 1975, Initial Reports of the Deep Sea Drilling Project, Volume 31: Washington, Govt. Printing Office, p. 883-895.

P Cook, H. E., and Zemmels, Ivar, 1976, X-ray mineralogy along the Line Islands, equatorial Pacific, in Schlanger, S. D., and others, Initial reports of the deep sea drilling project, Volume 33: Washington, Govt. Printing Office, v. 33, p. 539-555.

P Cook, H. E., Zemmels, I., and Matti, J. C., 1975, X-ray mineralogy data, Campbe11 Plateau and South Tasman Sea, Leg 29, Deep Sea Drilling Project, in Kennett and others, 1975, Initial reports of the Deep Sea Drilling Project, Volume 29: Washington, Govt. Printing Office, p. 1173-1186.

PA Core, K. L., Mattick, R. E., and Bayer, K. C., 1975, Seismic refraction records from a survey in the Gulf of Alaska: U.S. Geol. Survey OpenFile Rept. 75-283.

RAG Coury, A. B., Hendricks, T. A., and Tyler, T. F., 1977, Prospective hydrocarbon provinces of the world: Am. Assoc. Petroleum Geologists Bul1., v. 61, no. 5, p. 777. 
Craig, L. C., and Varnes, K. L., 1978, Interpretation of Mississippian history, Chapter B in Craig, L. C., and others, Paleotectonic investigation of the Mississippian system in the United States: U.S. Geo1. Survey Prof. Paper 1010 (in press).

PA Crowe, B. M., Howe11, D. G., and McLean, Hugh, 1976, Miocene volcanic and volcaniclastic rocks of Santa Cruz Island--evidence for offset along the Santa Cruz Island fault (abs.), in Neogene symposium volume, Spring 1976: San Francisco, Society Econ. Paleontologists and Mineralogists, p. 18.

PA Crowe, B. M., McLean, Hugh, Howell, D. G., and Higgins, R. E., 1976, Petrography and major-element chemistry of the Santa Cruz Island volcanics, in Howe11, D. G., ed., Aspects of the geologic history of the California continental borderland: Am. Assoc. Petroleum Geologists Misc. Pub. 24, p. 196-215.

OB Desborough, G. A., and Maughan, E. K., 1978, Concentration and residence of metals in the Meade Peak Member of the Phosphoria Formation, eastern Idaho--Potential metal resources of the future (abs.): Geol. Assoc. Canada, Soc. Econ. Geol., Vancouver, B.C., April 25-27, 1977, Program with Abstracts, v. 2, p. 15. the Appalachian basin, Part A: U.S. Geol. Survey Geol. Inv. Map I917A. the Greendale Syncline in southwest Virginia, in Cohee, G. V., and Wright, W. B., eds., Changes in stratigraphic nomenclature by the U.S. Geological Survey, 1975: U.S. Geo1. Survey Bu11. 1422-A, p. 4649 .

de Witt, Wallace, Jr., and Colton, G. W., 1978, Physical stratigraphy of the Genesee Formation in western and central New York: U.S. Geol. Survey Prof. Paper 1032-A (in press). data from Devonian and Silurian rocks in the Appalachian basin: U.S. Geol. Survey Geol. Inv. Map I-917B.

AG Dillon, W., Girard, 0., Jr., Weed, E., Sheridan, R., Dolton, G., Sable, E., Krivoy, H., Grim, M., Robbins, E., Rhodehame1, E., Amato, R., and Foley, N., 1975, Sediments, structural framework, petroleum potential, environmental conditions, and operational considerations of the United States South Atlantic Outer Continental Shelf: U.S. Geol. Survey Open-File Rept. 75-411.

RAG Dolton, Gordon L., 1977, Oil and gas potential of the northern and western Rocky Mountain regions: Geol. Soc. America Abs. with Programs, v. 9, no. 6, p. 720 .

RAG Dolton, G. L., Powers, R. B., and Sable, E. G., 1976, New approach to geological estimates of oil and gas resources by the U.S. Geological Survey (abs.): Am. Assoc. Petroleum Geologists Bull., v. 60, no. 4, p. 665 . 

U.S. Geological Survey: Okla. Geol. Survey, Oklahoma Geology Notes, v. 36, no. 3, Norman, Ok1a., p. 120.

Donovan, T. J., 1974, Petroleum microseepage at Cement, Oklahoma-Evidence, mechanism and exploration significance: Am. Assoc. Petroleum Geologists Bul1., v. 58, no. 3, p. 429-446.

1975, Landsat data contributions to Project Birddog (abs.): Pecora Conf., Sioux Falls, October 1975.

D

1975, The USGS Project BIRDDOG (Basic Investigation of Remotely Detectable Deposits of 0il and Gas) (abs.): Proc., Univ. of Kansas/AAPG/USGS Symposium on Remote Sensing for Energy Resources, Lawrence, Kansas.

D Donovan, T. J., Barringer, A. R., Foote, R. S., and Watson, R. D., 1976, Low altitude remote sensing experiments at Cement and Davenport oil fields, Oklahoma (abs.): Geophysics, v. 41, no. 2, p. 350.

D Donovan, T. J., Friedman, I., and Gleason, J. D., 1974, Recognition of petroleum-bearing traps by unusual isotopic compositions of carbonatecemented surface rocks: Geology, v 2, no. 7, p. 351-354.

D Donovan, T. J., and Noble, R. L., 1975, Identification of a petroleumrelated geochemical anomoly in surface rocks, Denver basin, Colorado, through the use of light aircraft: Proc. Univ. of Kansas/AAPG/USGS Symp. on Remote Sensing for Energy Resources.

D Donovan, T. J., Noble, R. L., Friedman, I., and Gleason, J. D., 1975, A possible petroleum-related geochemical anomaly in surface rocks, Boulder and Weld Counties, Colorado: U.S. Geol. Survey Open-File Rept. 75-47.

D Donovan, T. J., and Tailleur, I., 1975, Map showing paleocurrent and clast-size data from the Devonian-Mississippian Endicott Group, northern Alaska: U.S. Geol. Survey Misc. Field Studies Map MF-692.

PA Doyle, J. A., and Robbins, E. I., 1977, Angiosperm pollen zonation of the Continental Cretaceous of the Atlantic Coastal Plain and application to deep wells in the Salisbury Embayment: Palynology, v. 1, p. 4378 .

Emiliani, C., Gartner, S., Lidz, B., Eldridge, K., Elvey, D. K., Huang, T. C., Stipp, J. J., and Swanson, M. G., 1975, Paleoclimatological analysis of Late Quaternary cores from the northeastern Gulf of Mexico: Science, v. 189, no. 4208, p. 1083-1088.

Epstein, A. G., Epstein, J. B., and Harris, L. D., 1974, Conodont color alteration--an index to organic metamorphism: U.S. Geol. Survey Open-File Rept. 75-379. 
PA Fisher, M. A., 1976, Geology of the offshore lower Cook Inlet, Alaska, from seismic data (abs.): Am. Assoc. Petroleum Geologists Bull., v. 60 , no. 12, p. 2180-2181.

PA

PA

Foote, R. Q., Mattick, R. E., and Behrendt, J. C., 1974, Atlantic OCS (Outer Continental Shelf) Resource and Leasing Potential: U.S. Geol. Survey Open-File Rept. 74-348.

Fouch, T. D., 1975, Ear1y Tertiary continental sedimentation and hydrocarbon accumulations, northeastern Utah (abs.): AAPG/SEPM Ann. Mtg. Abs., v. 2 , p. 26 .

1975, Ear1y Tertiary continental sedimentation and hydrocarbon accumulations, northeastern Utah (abs.): Am. Assoc. Petroleum Geologists Bul1., v. 59, no. 5, p. 909.

OB 1975, Lithofacies and related hydrocarbon accumulations in Tertiary strata of the western and central Uinta Basin, Utah, in Deep drilling frontiers in central Rocky Mountains--a symposium: $1 \overline{975}$ Rocky Mountain Assoc. Geologists Guidebook, p. 163-173.

$\mathrm{OB}$ 1976, Revision of the lower part of the Tertiary System in the central and western Uinta Basin, Utah: U.S. Geol. Survey Bull. 1405C, p. C1-C7.

1976, Lithofacies and related hydrocarbon accumulations in Tertiary strata of the western and central Uinta Basin, Utah: Wyoming Geol. Assoc. Newsletter. 1977, Sheep Pass (Cretaceous(?) to Eocene) and associated closedbasin deposits (Eocene and 01igocene(?)) in east-central Nevada-implications for petroleum exploration (abs.): Am. Assoc. Petroleum Geologists Bul1., v. 61, no. 8, p. 1378.

OB Fouch, T. D., Cashion, W. B., Ryder, R. T., and Campbe11, J. A., 1976, Field guide to lacustrine and related nonmarine depositional environments in Tertiary rocks, Uinta Basin, Utah, in Epis, R. C., and Weimer, R. J., eds., Studies in Colorado field geology: Professional Contributions of Colorado School of Mines, Colorado School of Mines, no. 8, p. 358-385. 
Fouch, Thomas D., and Hanley, John H., 1977, Interdisciplinary analysis of some petroleum source rocks in east-central Utah--implications for hydrocarbon exploration of nonmarine rocks of Western United States (abs.): Am. Assoc. Petroleum Geologists Bull., v. 61, no. 8, p. 1377-1378.

OB Fouch, T. D., Hanley, J. H., Tschudy, R. H., and Claypoo1, G. E., 1977, Newly recognized petroleum source-rock units in east-central Utah-implications for detection of petroleum in nonmarine units (abs.): Am. Assoc. Petroleum Geologists Bull., v. 61, no. 5, p. 785-786.

R Fox, J. E., Lambert, P. W., Mast, R. F., Nuss, N. W., Rein, R. D., 1975, Maps showing porosity variations and geothermal gradients of the upper part of the Tensleep Sandstone and equivalents, Bighorn, Wind River, and Greater Green River Basins, Wyoming: U.S. Geol. Survey Open-File Rept. 75-280.

$\mathrm{R}$

1975, Porosity variation in the Tensleep Sandstone and its equivalent the Weber Sandstone, western Wyoming--a log and petrographic analysis, in Deep drilling frontiers in the central Rocky Mountains--a symposium: Rocky Mountain Assoc. Geologists Guidebook, p. 185-216.

Frezon, S. E., 1978, Oklahoma, Chapt. H in Paleotectonic Investigations of the Mississippian System: U.S. Geo1. Survey Prof. Paper 1010 (in press).

D Friedman, Irving, Denton, Ted., Roberts, A. A., and Reimer, G. M., 1976, A mobile helium sniffer for petroleum, uranium, and geothermal prospecting (abs.): Australian Geologic Congress.

OB Gill, J. R., and Hail, W. J., Jr., 1976, Stratigraphic sections across Upper Cretaceous Mancos-Mesaverde Boundary, Eastern Utah and western Colo: U.S. Geol. Survey Oil \& Gas Inv. Chart OC-68.

AG Girard, 0. W., 1975, Hydrocarbon potential of the United States Atlantic Outer Continental Shelf (abs.): Southeastern Geophys. Soc. News Bu11., v. 16, no. 3 .

PA Grantz, Arthur, Barns, P. W., Sleittreim, F. L., Reimnitz, E., Scott, E. W., Smith, R. A., Stewart, George, Toimil, L. J., 1976, Summary report--United States Beaufort Sea, Alaska area: U.S. Geol. Survey Open-File Rept. 76-830, 32 p.

AG Grantz, A., Holmes, M. L., and Kososki, B. A., 1975, Geologic framework of the Alaskan continental terrace in the Chukchi and Beaufort Seas: U.S. Geo1. Survey Open-File Rept. 75-124, 43 p., 18 figs.

PA 1975, Geologic framework of the Alaskan continental terrace in the Chukchi and Beaufort Seas, in Canada's Continental Margins: Calgary, Alberta, Canada, Canadian Soc. of Petroleum Geologists, p. 669-700.

AG Grim, M. S., Krivoy, H. L., Mattick, R. E., and Dillon, W. P., Summary of geophysical measurements on the Atlantic continental shelf between Cape Hatteras and Florida (abs.): EOS, Am. Geophys. Union Trans., v. 57, no. 4, p. 266. 
Grow, J. A., Mattick, R. E., and Schlee, John, 1977, Depth conversion of multichannel seismic-refraction profiles over the Atlantic outer continental shelf and upper continental slope between Cape Hatteras and Georges Bank (abs.): Am. Assoc. Petroleum Geologists Bull., v. 61, no. 5, p. 790 .

AG Grow, J. A., Schlee, J. S., Mattick, R. E., and Behrendt, J. C., 1976, Recent marine geophysical studies along the Atlantic continental margin (abs.): Geol. Soc. America Abs. with Programs, NE-SE Sec. Mtg., March 1976, Arlington, Va.

AG Grow, J. A., Sheridan, R. E., Behrendt, J. C., Mattick, R. E., 1975, A comparison of multichannel velocity data with earlier refraction velocity on the Atlantic margin between Cape Hatteras and Georges Bank (abs.): American Geophysicist Union Abs. with Programs, Washington, D.C.

OB Gutschick, R. C., 1976, Preliminary reconnaissance study of Lower and lower Upper Mississippian strata across northwestern Utah: U.S. Geol. Survey Open-File Rept. 76-200, 400 p.

OB, Gutschick, R. C., and Sandberg, C. A., 1977, Mississippian Radiolaria and agglutinate Foraminifera from deep-water sediments in Utah: Geol. Soc. America Abs. with Programs, v. 9, no. 5, p. 601.

OB Haley, B. R., 1976, Geologic map of Arkansas: Arkansas Geol. Map Series, Vo1. I and II.

P Halley, R. B., 1975a, Broken ooids--implications for ooid diagenesis (abs.): AAPG/SEPM Ann. Meetings Abs., v. 2, p. 56.

$\mathrm{P}$ 1975b, Vertical patterns of carbonate sedimentation in the Carrara Formation (Cambrian), Southern Great Basin (abs.): Geo1. Soc. America Abs. with Programs, v. 7, no. 7, p. 1092.

$P$ 1975c, Peritidal 1ithologies of Cambrian carbonate islands, in Ginsburg, R.N., and Klein, G. D., eds., Tidal Deposits--Carrara Formation, Southern Great Basin: p. 279-288.

$P$ 1976a, Pleistocene barrier bar seaward of the ooid shoal complex near Miami Beach, Florida (abs.): Jour. Florida Acad. of Science, March 1976.

$P$ $1976 \mathrm{~b}$, Textural variation within Great Salt Lake algal mounds, in Walter, M., ed., Stromatolites: New York, Elsevier, chapt. 8.5, p. 435-445.

$P$ 1977, Formation and fracture of Great Salt Lake ooids: Jour. Sed. Pet., v. 47, p. 1099-1120. 1978, Estimating pore and cement volume in thin section: Jour. Sed. Pet. (in press). 
Halley, R. B., and Harris, P. M., 1977, Fresh water cements from Joulters Cays, Great Bahama Bank (abs.): Am. Assoc. Petroleum Geologists Bu11., v. 61, p. 792 .

Halley, R. B., Shinn, E. A., Hudson, J. H., and Lidz, B. H., 1976, Recent and relict topography of Boo Bee Patch Reef, Belize, determined by diver-operated drilling device (abs.): Am. Assoc. Petroleum Geologists Bu11., v. 60, no. 4, p. 677.

1976, Pleistocene barrier bar seaward of the ooid shoal complex near Miami, Florida (abs.): Florida Scientist, v. 39, Supp1. 1, p. 11.

1977, Pleistocene barrier bar seaward of the ooid shoal complex near Miami, Florida: Am. Assoc. Petroleum Geologists Bull., v. 61, p. 519-526.

1977, Recent and relict topography of Boo Bee Patch reef, Belize: Proc., Third Internat. Coral Reef Symposium, Geology, v. 2, p. 29-36.

R Hancock, J. M., and Scholle, P. M., 1975, Chalk of the North Seas, Conference on the petroleum and Continental Shelf of North West Europe: London, Inst. of Petroleum, v. 1, p. 413-425.

$\mathrm{R}$ 1975, Chalk of the North Sea, Conference on the petroleum and Continental Shelf of North West Europe (abs.): London, Inst. of Petroleum, Proc., November 1974.

Hanley, J. H., Fouch, T. D., and Claypoo1, G. E., 1976, Paleontology, geochemistry, and depositional environments of some lower Tertiary coals, north-central Utah--implications for detection of continental petroleum source rocks (abs): Geol. Soc. America Abs. with Programs, v. 8 , no. 6, p. 902 .

G Harbridge, W., Pilkey, 0. H., Whaling, P., and Swetland, P., 1976, Sedimentation in the Lake of Tunis--A lagoon strongly influenced by man: Environmental Geology, v. 1, no. 4, p. 215-225.

Harris, L. D., 1975, Oil and gas data from the Lower Ordovician and Cambrian rocks of the Appalachian basin: U.S. Geo1. Survey Misc. Geo1. Inv. Map I-917D. illustrated by a seismic profile in the Valley and Ridge province of Tennessee: U.S. Geol. Survey Jour. Research, v. 4, no. 4, p. 379386.

1976b, Thin-skinned tectonics and potential hydrocarbon traps-illustrated by a seismic profile in the Valley and Ridge of Tennessee: U.S. Geo1. Survey Jour. Research, v. 4, no. 4, p. 379-387.

Harris, P. M., Lukas, K. J., and Halley, R. B., 1977, A comparison of endolith floras from Holocene-Pleistocene (Bahamas-Florida) ooids (abs.): Am. Assoc. Petroleum Geologists Bull., v. 61, p. 793. thin-skinned structural model to the Blue Ridge (abs.): Geol. Soc. America Abs. with Programs, v. 8, no. 2, p. 190. 
PA Hathaway, John C., Schlee, John S., Poag, C. Wylie, Valentine, Page C., Weed, E. G. A., Bothner, Michae1 H., Kohout, Francis A., Manheim, Frank T., Schoen, Robert, Miller, Robert E., and Schultz, David M., 1976, Preliminary summary of the 1976 Atlantic margin coring project of the U.S. Geological Survey: U.S. Geol. Survey Open-File Rept. 76844,217 p.

OB Hendricks, J. D., 1976, Simple Bouguer gravity maps of parts of White and adjacent counties, Arkansas: Ark. Geol. Comm., Geophysical Map Publications. Arizona: U.S. Geol. Survey Geophys. Map Series GP-905.

RAG Hendricks, T. A., 1974, Estimating resources of crude oil natural gas in inadequately explored areas (abs.): AAPG Research Symposium--Methods of Estimating the Volume of Undiscovered Oil and Gas Resources, Stanford University, Stanford, CA (8-74).

RAG 1975, Estimating resources of crude oil and natural gas in inadequately explored areas, in Haun, D., ed., Methods of estimating the volume of undiscovered oil and gas resources: Am. Assoc. Petroleum Geologists, Studies in Geology, no. 1, p. 19-22.

PA Howe11, D. G., 1975a, Early and middle Eocene shoreline offset by the San Andreas fault, southern California, in Crowell, J. C., ed., San Andreas fault in Southern California, a guide to the San Andreas fault from Mexico to Carrizo Plain: Calif. Div. Mines and Geology, Spec. Rept. 118, p. 69-74.

PA 1975b, The east Santa Cruz Basin fault, southern California continental borderland (abs.): Geol. Soc. America, Cordilleran Section, Abs. with Programs, v. 7, no. 3, p. 327.

PA 1975c, Eocene-paleogeography of the southern California continental borderland (abs): AAPG/SEPM Ann. Meetings Abstracts, Dallas, v. 2, p. 37-38.

PA 1975d, Middle Eocene paleogeography of southern California, in Future Energy Horizons of the Pacific Coast: Paleogene Symposium and Selected Technical Papers, AAPG-SEG-SEPM, Pacific Section, Annual Meeting, p. 272-293.

PA 1975e, Middle Eocene paleogeography of southern California: AAPGSEG-SEPM, Pacific Section, Programs, Long Beach, p. 35.

PA 1976a, A review of the estimates for the radiometric ages for the Relizian Stage of the Pacific Coast: Pacific Section, SEPM, Neogene Symposium Volume, p. 13-16.

PA 1976b, Preface for aspects of the geologic history of the California continental borderland: Am. Assoc. Petroleum Geologists, Pacific Sec., Misc. Pub. 24, p. 2-5. 
PA

PA

PA

PA

PA

PA

PA

PA

PA

PA

A

P

1976c, Neogene tectonic evolution of the Salinian block, westcentral California, Comment: Geology, v. 4, no. 9, p. 520.

1976d, Southern California Borderland Symposium: Geotimes.

1976e, Southern California borderland symposium: Am. Assoc. Petroleum Geologists Misc. Pub. 24.

1976f, Hypothesis suggesting $700 \mathrm{~km}$ of right-slip in California along northwestern-oriented faults, Reply: Geology, v. 4, no. 10, p. 632.

A 1976g, A model to accommodate up to 1100 kilometres of right-slip, Neogene displacement in the southwestern USA, in Howell, D. G., ed., Aspects of the geologic history of the Calif. continental borderland: Am. Assoc. Petroleum Geologists Misc. Pub. 24, p. 530-540.

A 1976h, Aspects of the geologic history of the California continental borderland, in Howell, D. G., ed., Aspects of the geologic history of the California continental borderland: Am. Assoc. Petroleum Geologists Misc. Pub. 24, p. 2-4.

A 1976i, Late-Miocene counterclockwise rotation of the south half of Santa Cruz Island, in Howe11, D. G., ed., Aspects of the geologic history of the California continental borderland: Am. Assoc. Petroleum Geologists Misc. Pub. 24, p. 449-454.

A 1976j, Inferred Eocene and Miocene cross sections of the southern California borderland, in Howell, D. G., ed., Aspects of the geologic history of the California continental borderland: Am. Assoc. Petroleum Geologists Misc. Pub. 24, p. 363-364.

PA Howel1, D. G., and McLean, Hugh, 1976, Middle Miocene paleogeography, Santa Cruz, and Santa Rosa Islands, in Howe11, D. G., ed., Aspects of the geologic history of the California continental borderland: Am. Assoc. Petroleum Geologists Misc. Pub. 24, p. 266-293. 1976, Basin analysis of lower and middle Miocene strata, Santa Rosa and Santa Cruz Islands, California (abs.): SEPM, Pacific Neogene Symposium, Tokyo, Japan, May 1976.

A Howe11, D. G., McLean, Hugh, and Vedder, J. G., 1976, Cenozoic tectonism on Santa Cruz Island, in Howell, D. G., ed., Aspects of the geologic history of the California continental borderland: Am. Assoc. Petroleum Geologists Misc. Pub. 24, p. 392-416.

Hudson, J. H., and Shinn, E. A., 1977, Stress banding in corals--normal and abnormal periodicity (abs.): Jour. Paleontology, v. 51, suppl. to No. 2, pt. III, p. 15 .

Hudson, J. H., Shinn, E. A., Halley, R. B., and Lidz, B. H., 1976a, Autopsy of a dead coral reef (abs.): Am. Assoc. Petroleum Geologists Bul1., v. 60, no. 4, p. 693.

1976b, Sclerochronology--a tool for interpreting past environments: Geology, v. 4, p. 361-364. 
Hunter, R. E., and Fox, J. E., 1978, Interpretation of depositional environments in the Fortress Mountain formation, central Arctic Slope, in Cobb, E. H., ed., United States Geological Survey in Alaska-a summary of results of 1975 and discussion of current projects: U.S. Geo1. Survey Circular (in press).

Isbel1, E. B., Spencer, C.W., and Seitz, Tommie, 1976, Petroleum geology of the Well Draw Field, Converse County, Wyoming, in Wyoming Geol. Assoc. 28th Ann. Field Conf. Guidebook, Geology and Energy Resources of the Powder River, 1976: p. 165-174, 1 p1.

PA Kahout, F. A., Walker, E. H., Bothner, M. H., Folger, D. W., Hathaway, J. C., and Weed, E. G. A., 1976, Fresh ground water under the continental shelf--implications from a deep test at Nantucket Island, Massachusetts: Am. Geophys. Union Trans., v. 57, no. 4, p. 248.

Kauffman, E. G., and Scholle, P. A., 1977, Abrupt biotic and environmental changes during peak Cretaceous transgressions in Euramerica: Jour. Paleontology, v. 51, no. 2 supp1., p. 16.

Kepferle, R. C., 1976, Prodelta turbidite fan apron in Borden Formation (Mississippian), Kentucky and Indiana: Am. Assoc. Petroleum Geologists Bul1., v. 60 , no. 4, p. 687. Kenwood Siltstone Member, Borden Formation (Mississippian), Kentucky and Indiana: U.S. Geol. Survey Prof. Paper 1007, 49 p. (Mississippian), Kentucky and Indiana, Chapter 16, in Kelling, G., and Stanley, D. S., Submarine canyon and fan sedimentation symposium volume: Dowden, Hutchinson and Ross, p. 224-238 (in press).

Kiteley, L. W., 1975a, Stratigraphy of the Upper Cretaceous Pierre Shale in the northwestern Denver basin (abs.): Am. Assoc. Petroleum Geologists Bu11., v. 59, no. 5, p. 914. northern Denver basin, Colo. and Wyoming with other areas in eastern Wyoming: U.S. Geol. Survey Open-File Rept. 75-33. Shale at the Francis Ranch, Laramie County, Wyoming: Mountain Geologist, v. 13, no. 1, p. 1-20. of the northern Denver basin and their relation to hydrocarbon accumulation: U.S. Geol. Survey Open-File Rept. 76-696. landscape geochemistry, and engineering geology characteristics, east-central Utah: U.S. Geol. Survey Open-File Rept. 77-513, p. 7283. 
NA Kososki, B. A., Reiser, H. N., Cavit, C. D., and Detterman, R. L., 1978, A gravity study of the northern part of the Arctic National Wildlife Range, Alaska: U.S. Geol. Survey Bull. 1440, 31 p. (in press).

AG Krivoy, H. L., Eppert, H. C., Jr., and Pyle, T. E., 1975, Preliminary Bouguer gravity map of the Gulf of Mexico and adjacent land areas: U.S. Geol. Survey Open-File Rept. 75-605.

AG 1976, Simple Bouguer gravity anomaly map of the Gulf of Mexico and adjacent land areas: U.S. Geol. Survey Geophys. Inv. Map GP-912.

Krivoy, H. L., and Girard, 0. W., Jr., 1976, The relationship of the Gulf of Mexico gravity field to hydrocarbon accumulation and to crustal structure (abs.): Offshore Tech. Conf., Houston, May 1976.

RAG Lennartz, F. E., and Miller, B. M., 1976, Inconsistencies in resource appraisal estimates resulting from area distortions inherent in some map projections (abs.): Am. Assoc. Petroleum Geologists Bull., v. 60, no. 4, p. 691-692.

R Lupe, R., and Ahlbrandt, Thomas, 1975, Reservoir quality aspects of eolian deposits (abs.): Am. Assoc. Petroleum Geologists Bull., v. 59, no. 5, p. 915-916.

$\mathrm{R}$

1975, Sandstone geometry, porosity and permeability distribution and fluid migration in eolian system reservoirs: U.S. Geol. Survey OpenFile Rept. 75-357.

PA Magoon, L. B., Adkison, W. L., Chmelik, F. B., Dolton, G. L., Fisher, M. A., Hampton, M. A., Sable, E. G., and Smith, R. A., 1976, Hydrocarbon potential, geologic hazards, and infrastructure for exploration and development of the lower Cook Inlet, Alaska: U.S. Geol. Survey OpenFile Rept. 76-449, 124 p.

PA Magoon, L. B., Adkison, W. L., and Egberg, R. M., 1976, Map showing geology, wildcat wells, Tertiary plant fossils localities, $\mathrm{K}-\mathrm{Ar}$ age dates, and petroleum operations, Cook Inlet area, Alaska: U.S. Geol. Survey Misc. Inv. Map I-1019.

PA Magoon, L. B., Adkison, W. L., Wolfe, J. A., Keller J. S., and Jones, D. L., 1976, Geologic framework of lower Cook Inlet, Alaska, with emphasis to onshore geology (abs.): Am. Assoc. Petroleum Geologists Bull., v. 60, no. 12, p. 2185.

G Magoon, L. B., and Claypoo1, G. E., 1978, Origin of Cook Inlet oil: Alaska Geol. Soc., Proc., 17 p. (in press).

PA Magoon, L. B., Hampton, M. A., Sable, E. G., Smith, R. A., and Chmelik, F. B., 1975, Hydrocarbon potential, geologic hazards, and the technology, time-frame and infrastructure for exploration and development of the Lower Cook Inlet: U.S. Geol. Survey Open-File Rept. 75-549. Jour., v. 74, no. 23, p. 166-172. 
RAG Mallory, W. W., 1975a, Accelerated national oil and gas resources appraisal (ANOGRE), in Haun, J. D., ed., Methods of estimating the volume of undiscovered oil and gas resources: Am. Assoc. Petroleum Geologists, Studies in Geology, no. 1, p. 23-30.

$\mathrm{OB}$

1975b, Middle and southern Rocky Mountains, northern Colorado Plateau, and eastern Great Basin, in Paleotectonic investigations of the Pennsylvanian System in the U.S., Part I--Introduction and regional analysis of the Pennsylvanian System: U.S. Geol. Survey Prof. Paper 853-N, p. 265-278.

RAG

1975c, Accelerated national oil and gas resource appraisal (ANOGRE)

(abs): AAPG-SEPM Annual Meetings Abs., Dallas, v. 2, p. 46.

OGS

1976a, USGS-AAPG digitized oil and gas field map of North America--a status report (abs.): Am. Assoc. Petroleum Geologists Bull., v. 60, no. 4, p. 694 .

OB 1976b, Regional stratigraphy; Pennsylvanian arkose and ancestral Rocky Mountains: U.S. Geol. Survey Prof. Paper 853, p. 265-278.

OB Mape1, W. J., Johnson, R. B., Bachman, G. O., and Varnes, K. L., 1978, Southern mid-continent and southern Rocky Mountain region, Chapter I, in Craig, L. C., and others, Paleotectonic investigations of the Mississippian system in the United States: U.S. Geol. Survey Prof Paper 1010 (in press).

PA Marlow, M. S., McLean, H., Schol1, D. W., and Powers, R. B., 1976, Prenomination report on the oil and gas potential of the Bering Sea shelf south of St. Lawrence Island, Alaska: U.S. Geol. Survey OpenFile Rept. 76-785, 60 p.

PA Marlow, M. S., McLean, H., Vallier, T. L., Scholl, D. W., Gardner, J. V., and Powers R. B., 1976, Pre-nomination report on the regional geology, oil and gas potential and environmental hazards of the Bering Sea shelf south of St. Lawrence Island, Alaska: U.S. Geol. Survey OpenFile Rept. 76-785, 98 p.

AG Mattick, R. E., 1977, Geologic setting, in Scholle, P. A., ed., Geological studies on the COST No. B-2 well, U.S. mid-Atlantic outer continental shelf area: U.S. Geo1. Survey Circ. 750, p. 4-7.

AG Mattick, R. E., Bayer, K. C., and Scholle, P. A., 1977, Petroleum potentia1 of a possible Lower Cretaceous reef trend beneath the U.S. Atlantic continental slope (abs.): Am. Assoc. Petroleum Geologists Bull., v. 61, p. 811.

AG Mattick, Robert E., Folger, David N., Foley, Neil T., Dolton, Gordon L., and Bayer, Kenneth C., 1976, Summary report of the sediments, structural framework, petroleum potential, environmental conditions, and operational considerations of the United States mid-Atlantic continental shelf: U.S. Geol. Survey Open-File Rept. 76-532. 

preliminary report on U.S. Geol. Survey geophysical studies of the northeastern United States Outer Continental Shelf: Am. Assoc. Petroleum Geologists, v. 58, no. 6, p. 1179-1190.

AG Mattick, R. E., Girard, 0. W., Scholle, P. A., and Grow, J. A., 1978, Petroleum potential of the U.S. Atlantic outermost slope, rise, and abyssal plain: Am. Assoc. Petroleum Geologists (in press). A., Taylor, D. J., Krivoy, H. L., and Bayer, D. K., 1975, Sediments, structural framework, petroleum potential, environmental conditions, and operational considerations of the United States Mid-Atlantic Outer Continental Shelf: U.S. Geol. Survey Open-File Rept. 75-61.

AG Mattick, Robert E., Scholle, Peter A., Bayer, Kenneth C., and Dolton, Gordon L., 1976, Second Atlantic sale may involve tracts off Virginia, Maryland: $0 i 1$ and Gas Jour., v. 74, no. 47, p. 168-175.

Maughan, E. K., 1975a, Preliminary unevaluated map showing distribution of organic carbon in Meade Peak and Retort Members of the Phosphoria Formation (Permian) in parts of Utah, Idaho, Wyoming, and Montana: U.S. Geol. Survey Open-File Rept. 75-101. abs.): Am. Assoc. Petroleum Geologists Bull., v. 59, no. 5, p. 9167.

1975c, Organic carbon in shale beds of the Permian Phosphoria Formation of eastern Idaho and adjacent States--a summary report in Geology and mineral resources of the Bighorn Basin: Wyoming Geol. Assoc. Guidebook 27th Ann. Field Conf., p. 107-115. 1976a, Montana, North Dakota, northeastern Wyoming and northern South Dakota, Chapt. 0, in Paleotectonic investigations of the Pennsylvanian System in the United States: U.S. Geol. Survey Prof. Paper 853, p. 279-293.

1976b, Organic carbon and selected element distribution in the phosphatic shale members of the Permian Phosphoria Formation, eastern Idaho and parts of adjacent states: U.S. Geol. Survey Open-File Rept. 76-577, 92 p. Phosphatic Shale Members of the Phosphoria Formation, eastern Idaho and parts of adjacent States (abs.): Geol. Assoc. Canada, Soc. Econ. Geol., Vancouver, B.C., April 25-27, 1977, Program with Abstracts, v. 2 , p. 58 .

P McKee, 1975, The Supai Group--subdivision and nomenclature, in Contributions to Stratigraphy: U.S. Geo1. Survey Bull. B-1395-J.

P McKee, E. D., 1976, Arizona, in Part I--Introduction and regional analyses of the Pennsylvanian System, Paleotectonic investigations of the Pennsylvanian System in the U.S.: U.S. Geo1. Survey Prof. Paper 853, p. 295-309. 
McKee, E. D., and Breed, C. S., 1976, Sand Seas of the World, in ERTS-1--A new window on our planet: U.S. Geol. Survey Prof. Paper 929, p. 8188 .

P McKee, E. D., Breed, C. S., and Fryberger, S. G., 1977, Desert sand seas, in Skylab explores the earth: NASA SP-380, Chap. 2, p. 5-48.

P. McKee, E. D., Breed, C. S., Fryberger, S., Gebe1, D., and McCauley, C., 1974, A synthesis of sand seas throughout the world--Type III Final Report for $7 / 1 / 72-3 / 31 / 74$, in NASA Earth Resources Survey Program Weekly Abstracts, National Technical Information Service, 93-74-41, Oct. 14, 1974, p. 134: NASA CR 139226, 95 p.

OB McKee, E. D., and Crosby, E. J., 1976, Paleotectonic investigations of the Pennsylvanian System in the U.S., Part I--Introduction and regional analyses of the Pennsylvanian System; Part II--Interpretive summary and special features of the Pennsylvanian System: U.S. Geol. Survey Prof. Paper 853, pt. I, p. 1-17; pt. II, p. 1-23.

P McKee, E. D., and Moiola, R. J., 1975, Geometry and growth of the White Sands dune field, New Mexico: U.S. Geol. Survey Jour. Research, v. 3, no. 1, p. 59-66.

PA McLean, Hugh, 1976, Block fault model of Santa Cruz Island, in Howe11, D. G., ed., Aspects of the geologic history of the California continental borderland: Am. Assoc. Petroleum Geologists Misc. Pub. 24, p. 560561. Washington--a submarine fan complex: Jour. Sed. Petrology, v. 47, no. 1, p. $78-88$.

PA McLean, Hugh, Crowe, Bruce, and Howe11, David, 1976, Source of Blanca Formation volcaniclastic rocks and strike-slip faulting on Santa Cruz Island, Calif., in Howe11, D. G., ed., Aspects of the geologic history of the California continental borderland: Am. Assoc. Petroleum Geologists Misc. Pub. 24, p. 294-308.

PA McLean, Hugh, and Howe11, D. G., 1976, Elements of tectonism deduced from Miocene strata, northern Channel Islands, California, in Neogene Symposium volume, Spring 1976: Soc. Econ. Paleontologists and Mineralogists, Pacific Sec., San Francisco, p. 17.

PA McLean, Hugh, Howe11, D. G., and Vedder, J. G., 1975, The Miocene-basement unconformity, Santa Cruz Island, California (abs.): Geol. Soc. America Abs. with Programs, v. 7, no. 3, p. 346.

PA 1976, Miocene strata on Santa Cruz and Santa Rosa Islands--a reflection of tectonic events in the southern California borderland, in Howe11, D. G., ed., Aspects of the geologic history of the California continental borderland: Am. Assoc. Petroleum Geologists Misc. Pub. 24, p. 241-254.

OB Merewether, E. A., 1975, Mesozoic rocks, in U.S. Congress, Senate Committee on Interior and Insular Affairs report--Mineral and water resources of South Dakota: U.S. 94th Cong., 1st Sess., 313 p. 
Merewether, E. A., Cobban, W. A., Matson, R. M., and Magathan, W. J., 1977, Stratigraphic diagrams with electric logs of Upper Cretaceous rocks, Powder River Basin, Johnson, Campbell, and Crook Counties, Wyoming, section A-A': U.S. Geo1. Survey Oil and Gas Inv. Chart OC73.

1977, Stratigraphic diagrams with electric logs of Upper Cretaceous rocks, Powder River Basin, Natrona, Campbe11, and Weston Counties, Wyoming, section B-B': U.S. Geol. Survey Oil and Gas Inv. Chart OC74.

1977, Stratigraphic diagrams with electric logs of Upper Cretaceous rocks, Powder River Basin, Natrona, Converse, and Niobrara Counties, Wyoming, section C-C': U.S. Geol. Survey Oil and Gas Inv. Chart OC75 .

1977, Stratigraphic diagrams with electric logs of Upper Cretaceous rocks, Powder River Basin, Sheridan, Johnson, Campbe11, and Converse Counties, Wyoming, section D-D': U.S. Geol. Survey Oil and Gas Inv. Chart $0 \mathrm{C}-76$.

OB Merewether, E. A., Cobban, W. A., and Ryder, R. T., 1975, Lower Upper Cretaceous strata, Bighorn Basin, Wyoming and Montana, in Geology and mineral resources of the Bighorn Basin: Wyoming Geol. Assoc. Guidebook 27th Ann. Field Conf., p. 73-84.

OB Merewether, E. A., Cobban, W. A., and Spencer, C. W., 1976, The Upper Cretaceous Frontier Formation in the Kaycee-Tisdale Mountain area, Johnson County, Wyoming: Wyoming Geol. Assoc. Guidebook 28th Annual Field Conf., Powder River, p. 33-44.

T Milici, R. C., and Harris, L. D., 1976, Structural subdivision of the valley and ridge and Appalachian physiographic provinces (abs.): Geol. Soc. America Abs. with Programs, v. 8, no. 2, p. 229-30.

OB Miller, B. M., 1974, An investigation of geothermal and geopressure relationships as a tool for petroleum exploration (abs.): Am. Assoc. Petroleum Geologists Bul1., v. 58, no. 5, p. 916. 1975, The application of trend surface analysis to geothermal and geopressure data in petroleum exploration (abs.): AAPG-SEPM Ann. Mtgs. Abs., Dallas, v. 2, p. 51; also in Petroleum Abstracts, v. 15, no. 22, May 31, 1975, 非205, 307.

RAG 1975, A comparison of the basic methods used in estimating hydrocarbon resources (abs.): AAPG-SEPM Ann. Mtgs. Abstracts, Dallas, v. 2, p. 52; also in Petroleum Abstracts, v. 15, no. 22, May 31, 1975, 非205, 365 .

RAG 1975, A comparison of the basic methods used in estimating hydrocarbon resources (abs.): Rocky Mtn. Energy Resources Discovery and Development Program with Abstracts, p. 23 (Albuquerque).

RAG 1975, Undiscovered oil and gas in the U.S.: Geotimes, v. 20, no. 9, p. 23. 

the Appalachain Basin, 1859-1972: U.S. Geol. Survey Bu11. 1409.

RAG 1976, New concepts in methodology for processing U.S.G.S. probabilistic assessments of undiscovered hydrocarbons in the U.S. petroleum provinces (abs.): Am. Assoc. Petroleum Geologists Bull.,v. 60, no. 8, p. 1404.

RAG 1976, Probabilistic and computer methodologies used by the U.S. Geological Survey for geological estimates of undiscovered oil and gas resources in the United States (abs.): Preprints XIV APCOM Symposium, Penn State Univ.

RAG 1976, Geological estimates of undiscovered recoverable oil and gas resources in the U.S.: Geol. Soc. America, Penrose Conference on the "Role of the Geologist in Society", Huntsville, Texas, March 14-19.

RAG 1976, Probabilistic assessments by the U.S. Geological Survey of undiscovered oil and gas resources in the United States petroleum provinces: 25th Internat. Geologic Congress, Australia, August.

RAG 1977, A review and application of petroleum finding rate methodologies to the appraisal of undiscovered oil and gas resources (abs.): Am. Assoc. Petroleum Geologists Bul1., v. 61, no. 5, p. 813.

RAG 1977, A computer based information system designed for the integration and evaluation of petroleum resource data (abs.): AAPG Conference on Exploration Data Synthesis, Tucson, Arizona, March 28-30, 1977, Tech. Program, p. 5.

RAG Miller, B. M., and Thomsen, H. L., 1976, Probabilistic and computer methodologies used by the U.S.G.S. for geological estimates of undiscovered oil and gas resources in the United States (abs.): Am. Assoc. Petroleum Geologists Bul1., v. 60, no. 4, p. 698.

RAG 1976, Probabilistic and computer methodologies used by U.S. Geological Survey for geologic estimates of undiscovered oil and gas resources in United States, in Tomorrow's oil from today's provinces: San Francisco, AAPG/SEPM, Selected Papers 51st Ann. Mtg., p. 1-18.

RAG Miller, B. M., Thomsen, H.L., Dolton, G., Coury, A. B., Hendricks, T. A., Lennartz, F. B., Powers, R. B., Sable, E. G., and Varnes, K. L., 1975, Geological estimates of undiscovered recoverable oil and gas resources in the United States: U.S. Geo1. Survey Circ. 725.

OB Miller, R. L., 1975, Oil and gas data from the Upper and Middle Ordovician rocks in the Appalachian basin: U.S. Geol. Survey Misc. Inv. Series I-917-C.

AG Minard, J. P., Perry, W. J., Jr., Weed, E. G. A., Rhodehame1, E. C., Robbins, E. I., and Mixon, R. B., 1974, Preliminary report on geology along Atlantic continental margin of northeastern United States: Am. Assoc. Petroleum Geologists Bul1., v. 58, no. 6, pt. 2, p. 1169-1178. 
PA Molnia, B. F., Carlson, P. R., and Bruns, T. R., 1976, Report on the environmental geology OCS area, eastern Gulf of Alaska: U.S. Geol. Survey Open-File Rept. 76-206, 28 p., 18 figs.

PA Moore, G. W., and Beyer, L. A., 1975, Seismic reflection profiles R/V Kelez Nov.-Dec. 1973 continental borderland of southern California: U.S. Geol. Survey Open-File Rept. 75-330.

OB Mudge, M. R., Earhart, R. L., and Rice, D. D., 1977, Preliminary bedrock geologic map of part of the northern Disturbed Belt, Lewis and Clark, Teton, Pondera, Glacier, Flat Head, and Powell Counties, Montana: U.S. Geol. Survey Open-File Rept. 77-25.

R Nuss, N. W., Fox, J. E., Lambert, P. W., Mast, R. F., and Rein, R. D., 1975, A study of reservoir quality in the Tensleep Sandstone, western Wyoming (abs.): AAPG-SEPM Ann. Mtgs Abstracts, Dallas, v. 2, p. 56.

$\mathrm{R}$ 1975, A study of reservoir quality in the Tensleep Sandstone, western Wyoming (abs.): Am. Assoc. Petroleum Geologists Bull., v. 59, no. 5, p. 918-919.

G Palacas, J. G., Gerrild, P. M., Love, A. H., and Roberts, A. A., 1975, Organic matter and hydrocarbons in barrier island quartzose sands, northeastern Gulf of Mexico (abs.): AAPG-SEPM Ann. Mtgs. Abstracts, Dallas, v. 2, p. 58 .

G

1976, Baseline concentrations of hydrocarbons in barrier-island quartz sands, northeastern Gulf of Mexico: Geology, v. 4, no. 2, p. 81-84.

PA Paul, R. G., Arnal, R. E., Baysinger, J. P., Claypoo1, G. E., Ho1te, J. L., Lubeck, C. M., Patterson, J. M., Poore, R. Z., Slettene, R. L., Sliter, W. V., Taylor, J. C., Tudor, R. B., and Webster, F. L., 1976, Geological and operational summary, southern California deep stratigraphic test OCS-CAL 75-7 No. 1, Cortes Bank area offshore southern California: U.S. Geol. Survey Open-File Rept. 76-232, 65 p.

T Perry, W. J., Jr., 1975, Tectonics of the western Valley and Ridge Fold Be1t, Pendleton County, West Virginia--a summary report: U.S. Geol. Survey Jour. Research, v. 3, no. 5, p. 583-588.

$\mathrm{T}$

1976, Possibility of abnormally high fluid pressures during folding and faulting in eastern West Virginia (abs.): Am. Assoc. Petroleum Geologists Bul1., v. 60, no. 4, p. 707.

AG Perry, W. J., Jr., Minard, J. P., Weed, E. G. A., Robbins, E. I., and Rhodehame1, E. C., 1975, Stratigraphy of Atlantic coastal margin of United States north of Cape Hatteras--Brief survey: Am. Assoc. Petroleum Geologists Bull., v. 59, no. 9, p. 1529-1548.

T Perry, W. J., Jr., and Radar, E. K., 1976, Structural evolution of Allegheny and Little North Mountain structural fronts in eastern West Virginia and Virginia (abs.): Geol. Soc. America Abs. with Programs, v. 8, no. 2 , p. 243-244. 
Peterson, F., and Ryder, R. T., 1975, Cretaceous rocks in the Henry Mountains Region, Utah and their relation to neighboring regions, in Canyonland Country: Four Corners Guidebook, 8th Field Conf., p. 167189.

PA Plafker, G., Bruns, T., Page, R., 1975, Interim report on petroleum resource potential and geologic hazards in the outer continental shelf of the Gulf of Alaska Tertiary Province (McCulloh, T., Dolton, G. L., Powers, R. B., and Sable, E. G., Resource estimate): U.S. Geol. Survey Open-File Rept. 75-592, p. 50-53.

OB Poole, F. G., Sable, E. G., and Sandberg, C. A., 1975, Petroleum source beds in Mississippian flysch, eastern Great Basin and western Rocky Mountains (abs.): Am. Assoc. Petroleum Geologists Bull., v. 59, no. 5, p. 920.

OB Poole, F. G., and Sandberg, C. A., 1975, Allochthonous Devonian eugeosynclinal rocks in Tóquima Range, central Nevada: Geol. Soc. America Abs. with Programs, v. 7, no. 3, p. 361. 1977, Mississippian paleogeography and tectonics of the western United States, in Stewart, J. H., Stevens, C. H., and Fritsche, A. E., eds., Paleozoic paleogeography of the Western United States: Soc. Econ. Paleontologists and Mineralogists, Pacific Sec., Pacific Coast Paleogeography Symposium 1, p. 67-85.

OB Poole, F. G., Sandberg, C. A., and Boucott, A. J., 1977, Silurian and Devonian paleogeography of western United States, in Stewart, J. H., Stevens, C. H., and Fritsche, A. E., eds., Paleozoic paleogeography of the Western United States: Soc. Econ. Paleontologists and Mineralogists, Pacific Sec., Pacific Coast Paleogeography Symposium 1 , p. 39-65.

RAG Powers, R. B., 1976, Crude oil resources (Chap. 3), Natural gas and NGL resources (Chap. 4), in Energy resources of the United States: A revision of U.S. Geological Survey Circular 650 (1972), 21 p.

RAG 1977, Assessment of oil and gas resources in the Idaho-Wyoming thrust belt (abs.): Am. Assoc. Petroleum Geologists Bull., v. 61, no. 8, p. 1388 .

G Price, L. C., 1974, The solubility of petroleum in water as a function of temperature and salinity and its significance to petroleum migration (abs.): Am. Assoc. Petroleum Geologists Bull., v. 58, no. 10, p. 2217.

G 1975, Crude oil dissolved in deep geothermal waters of petroleum basins--a possible new energy resource (abs.): Am. Assoc. Petroleum Geologists Bul1., v. 59, no. 5, p. 920.

G

1975, Evidence for and use of the model of a hot deep origin of petroleum in exploration (abs.): AAPG-SEPM Ann. Mtgs. Abstracts, Dallas, v. 2, p. 60-61. 

primary migration: Am. Assoc. Petroleum Geologists Bul1., v. 60, no. 2 , p. 213-244.

Rader, E. K., and Perry, W. J., Jr., 1976, Stratigraphy as a key to the arch-related origin of the Little North Mountain structural front, Virginia and West Virginia (abs.): Am. Assoc. Petroleum Geologists Bul1., v. 60, no. 9, p. 1623. County, Virginia: Virginia Minerals, v. 22, no. 4., p. 37-45.

Reimer, G. M., Roberts, A. A., and Denton, E. H., 1976, Diurnal effects on the helium concentration in soil-gas and near-surface atmosphere: U.S. Geol. Survey Open-File Rept. 76-715. 1976, The use of helium detection to locate energy resources (abs.): Geol. Soc. America Annual Meeting, Denver.

Reynolds, M. W., 1976, Influence of recurrent Laramide structural growth on sedimentation and petroleum accumulation, Lost Solider area, Wyoming: Am. Assoc. Petroleum Geologists Bull., v. 60, no. 1, p. 1233.

Reynolds, M. W., Ahlbrandt, T. S., Fox, J. E., and Lambert, P. W., 1975, Description of selected drill cores from Paleozoic rocks, Lost Soldier oil field, south-central Wyoming--Part I-Wells 114A; Tract 13, C-128; Tract 4, C-14; Tract 10, T-1; Tract 10, C-2: U.S. Geo1. Survey Open-File Rept. 75-662, 73 p. central Wyoming (abs.): Am. Assoc. Petroleum Geologists Bull., v. 60, no. 8, p. 1407.

1976, Description of selected drill cores from Paleozoic rocks, Wertz oil field, south-central Wyoming. Part I. Well 27 A,B,C,; 46 A, B, C, and E; 42 B; W. Wertz 2: U.S. Geol. Survey Open-File Rept. 76-377, $54 \mathrm{p}$.

Reynolds, M. W., and Fox, J. E., 1976, Description of selected drill cores from Paleozoic and Precambrian rock, Lost Soldier oil field, southcentral Wyoming: U.S. Geol. Survey Open-File Report 76-74, 50 p., 12 tables. Charleston, South Carolina: U.S. Geol. Survey Open-File Report 75247. on the B-2 COST well, U.S. mid-Atlantic outer continental shelf area: U.S. Geol. Survey Circular 750, p. 53-74. 
1977, Lithologic descriptions, in Scholle, P. A., ed., Geologic studies on the B-2 COST wel1, U.S. mid-Atlantic outer continental shelf area: U.S. Geol. Survey Circular 750, p. 23-52.

G Rice, D. D., 1975, Origin and significance of natural gases of the Montana Plains (abs.): Am. Assoc. Petroleum Geolgists Bull., v. 59, no. 5, p. 921. Plains, Montana, North Dakota, and South Dakota: U.S. Geol. Survey Bu11. 1422-A, p. A66-A67.

G 1975, Origin of shallow accumulations of natural gas (abs.): Geol. Soc. America Abs, with Programs, v. 7, no. 7, p. 1245. 1975, Origin of and conditions for shallow accumulations of natural gas, in Geology and mineral resources of the Big Horn Basin: Wyoming Geol. Assoc. Guidebook 27th Ann. Field Conf., p. 267-271. 1975, Origin and significance of natural gases of Montana: U.S. Geo1. Survey Open-File Rept. 75-188. Plains, Montana, North Dakota, and South Dakota: U.S. Geol. Survey Bu11. 1422-A, p. A66-A67. 1976, Depositional environments of the Eagle Sandstone, northcentral Montana--an aid for hydrocarbon exploration: U.S. Geol. Survey Open-File Rept. 76-423, 12 p. 1976, Stratigraphic sections from well logs and outcrops of Cretaceous and Paleocene rocks, northern Great Plains, Montana: U.S. Geol. Survey Oil and Gas Inv. Chart OC-71. 1976, Stratigraphic sections from wel1 logs and outcrops of Cretaceous and Paleocene rocks, northern Great Plains, North and South Dakota: U.S. Geol. Survey $0 i 1$ and Gas Inv. Chart OC-72. northern Great Plains: U.S. Geol. Survey Oil and Gas Inv. Chart OC70 . central Montana--an aid for hydrocarbon exploration (abs.): Am. Assoc. Petroleum Geologists Bull., v. 60, no. 8, p. 1408.

G 1976, Shallow gas accumulations--their origin and significance for future exploration (abs.): Am. Assoc. Petroleum Geologists Bull., v. 60 , no. 4, p. 714 . central Montana: Am. Assoc. Petroleum Geologists Bull., v. 62 (in press). 
Rice, D. D., and Cobban, W.A., 1977, Cretaceous stratigraphy of the Glacier National Park area, northwestern Montana, in Cordilleran geology of southern Alberta and adjacent areas: Can. Soc. Petroleum Geologists Spec. Pub., v. 25, no. 4, p. 828-841.

Richardson, Evan S., Ball, Mahlon, Harrison, C. G. A., Bock, W., Nagle, F., Chermak, A., and Varchol, D., 1976, The old Bahama Channe1-Tectonic boundary between the Bahamas and Greater Antilles (abs.): Geol. Soc. America Abs, with Programs, v. 8, no. 6, p. 1069.

Robbins, E. I., Geothermal gradient, in Scholle, P. A., eds., Geological studies in the B-2 COST we11, U.S. mid-Atlantic Outer Continental Shelf area: U.S. Geol. Survey Circ. 750, p. 44-45. Color alteration of visible organics, in Scholle, P. A., ed., Geological studies on the B-2 COST we11, U.S. mid-Atlantic Outer Continental Shelf area: U.S. Geol. Survey Circ. 750, p. 60-62. 1976, Scotian shelf geothermal gradients (abs.): Am. Assoc. Petroleum Geologists, v. 60, no. 4, p. 714-715.

Robbins, E. I., and Doyle, J. A., 1975, Cretaceous palynostratigraphy of four deep wells in the Salisbury embayment of the Atlantic Coastal Plain (abs.): Am. Assoc. Strat. Palynologists, Abs. of Mtg., Houston, October 1975. Salisbury embayment of the Atlantic Coastal Plain (abs.): Palynology, v. 1 , p. 176 .

AG Robbins, E. I., Perry, W. J., Jr., and Doyle, J. A., 1975, Palynological and stratigraphic investigations of four deep wells in the Salisbury Embayment of the Atlantic Coastal Plain: U.S. Geo1. Survey Open-File Report 75-307.

AG Robbins, E. I., and Rhodehame1, E. C., Geothermal gradients under the Scotian She1f: Oil and Gas Jour., v. 74, no. 9, p. 143-145.

D Roberts, A. A., 1975, Helium surveys over known geothermal resource areas in the Imperial Valley, California: U.S. Geol. Survey Open-File Rept. 75-427.

D Roberts, A. A., Dalziel, Mary, Pogorski, L. A., and Quirt, S. G., 1976, A possible petroleum related helium anomaly in the soil gas, Boulder and Weld Counties, Colorado: U.S. Geol. Survey Open-File Rept. 76544 .

D Roberts, A. A., Friedman, I., Donovan, T. J., and Denton, E. H., 1975, Helium survey, a possible technique for locating geothermal reservoir: Geophysical Research Letters, v. 2, p. 209-210.

PA Roberts, A. E., 1975, Selected geological 1iterature on the California continental borderland and adjacent areas, to January 1, 1975: U.S. Geo1. Survey Circ. 714. 
Rose, P. R., 1975, Developing role for U.S. Geological Survey's Oil and Gas Branch in the energy crisis (abs.): AAPG-SEPM Ann. Mtg. Abs., v. 2, p. 64, (Da11as).

1976, Key wells and outcrops for regional analysis of Mississippian rocks, Western United States: U.S. Geol. Survey Open-File Rept. 76242,28 p., 1 fig.

1976, Mississippian carbonate shelf margins, western United States:

U.S. Geol. Survey Jour. Research, v. 4, no. 4, p. 445-465. Limestone, western United States: Geol. Soc. America Abs. with Programs, v. 8, no. 6, p. 1075.

Ryder, R. T., 1975, A major unconformity in Upper Cretaceous rocks, Henry basin, Utah (abs.): Geol. Soc. America Abs. with Programs, v. 7, no. 7, p. 1255.

1977, Hydrocarbon potential of the Archuleta anticlinorium, Brazos uplift, and Chama basin in southwestern Colorado: Am. Assoc. Petroleum Geologists Bu11., v. 61, no. 8, p. 1389-1390.

Ryder, R. T., Anderson, R. C., Balch, A. H., Lee, M. W., and Head, W. J., 1976, Synthetic seismic sections of selected stratigraphic traps and aquifers in the southeast Powder River Basin, Wyoming: Am. Assoc. Petroleum Geologists Bul1., v. 60, no. 4, p. 718.

1976, Synthetic seismic sections of selected stratigraphic traps and aquifers in the southeast Powder River Basin, Wyoming: Am. Assoc. Petroleum Geologists Bull., v. 60, no. 8, p. 1409.

OB Ryder, R. T., and Fouch, T. D., 1974, Stratigraphic framework and nature of Uinta Basin, Utah oil shales and their implications for the evolution of early Tertiary Lake Uinta: Geol. Soc America Abs. with Programs, v. 6, no. 7, p. 935-936.

OB Ryder, R. T., Fouch, T. D., and E1ison, J. H., 1976, Early Tertiary sedimentation in the western Uinta Basin, Utah: Geol. Soc. America Bul1., v. 87, no. 4, p. 496-512.

OB Sandberg, C. A., 1975, Conodont biofacies of Late Devonian Polygnathus styriacus Zone in western United States (abs.): Geol. Soc. America Abs. with Programs, v. 7, no. 6, p. 847-848. flysch sequence in east-central Idaho: U.S. Geol. Survey Bull. 1405E. in western United States, in Barnes, C. R., ed., Conodont Paleoecology: Geo1. Assoc. Canada Spec. Paper 15, p. 171-186. 

possible solutions: Geol. Soc. America Abs. with Programs, v. 9, no. 5, p. 648-649.

OB Sandberg, C. A., and Gutschick, R. C., 1976, Paleotectonic, biostratigraphic, and economic significance of Osagean starved basin in Utah (abs): Geo1. Soc. America Abs, with Programs, v. 8, no. 6, p. 1083 and 1085 .

1977, Paleotectonic, biostratigraphic, and economic significance of Osagean to early Meramecian starved basin in Utah: U.S. Geol. Survey Open-File Rept. 77-121.

1977, Deep-water Osagean conodont faunas from a starved basin in Utah: Geol. Soc. America Abs, with Programs, v. 9, no. 5, p. 649.

OB Sandberg, C. A., Ha11, W. E., Batchelder, J. N., and Axelsen, Claus, 1975, Stratigraphy, conodont dating, and paleotectonic interpretation of type Milligen Formation (Devonian), Wood River area, Idaho: U.S. Geo1. Survey Jour. Research, v. 3, no. 6, p. 707-720.

Sandberg, C. A., and Maughan, E. K., 1975, Petroleum geology of middle and upper Paleozoic rocks of Cordilleran miogeosyncline, western United States: Geo1. Soc. America Abs, with Programs, v. 7, no. 7, p. 1257.

Sandberg, C. A., and Poole, F. G., 1975, Petroleum source beds in Pilot Shale of eastern Great Basin (abs.): Am. Assoc. Petroleum Geologists Bul1., v. 59, no. 5, p. 921-922. 1975, Petroleum source beds in Pilot Shale of eastern Great Basin-Talk for Oil and Gas Session I, Rocky Mtn. Sec. Meeting, Am. Assoc. Petroleum Geologists, Albuquerque, New Mexico, June 2, 1975: U.S. Geo1. Survey Open-File Rept. 75-371, 13 p.

Sandberg, C. A., and Ziegler, Willi, 1976, Working zonation and refined speciation of Siphonodella (Conodonta, Upper Devonian and Lower Carboniferous) (abs.): Geol. Soc. America Abs. with Programs, v. 8, no. 4, p. 506-507.

Sando, W. J., Dutro, J. T., Jr., Sandberg, C. A., and Mamet, B. L., 1976, Revision of Mississippian stratigraphy, eastern Idaho and northeastern Utah: U.S. Geo1. Survey Jour. Research, v. 4, no. 4, p. 467-479.

PA Schlee, J. S., Behrendt, J. C., Mattick, R. E., Taylor, P. T., 1975, Structure of continental margin off mid-Atlantic States (Baltimore Canyon Troughs): U.S. Geol. Survey Open-File Rept. 75-60.

PA Schlee, J. S., Grow, J. A., Robb, J. M., Behrendt, J. C., Mattick, R. E., 1975, Tectonic framework-eastern U.S. Atlantic margin, Cape Hatteras to Georges Bank (abs.): Geol. Soc. America Abs. with Programs, v. 7, no. 7, p. 1260 . 
PA Schlee, J. S., Mattick, R. E., Taylor, D. J., Girard, 0. W., Grow, J. A., Rhodehame1, E. C., Perry, W. J., Jr., Bayer, D. C., Furbush, M., Clifford, C. P., and Lees, J. A., 1975, Sediments, structural framework, petroleum potential, environmental conditions, and operational considerations of the United States North Atlantic Outer Continental Shelf: U.S. Geol. Survey Open-File Rept. 75-353.

OB Schmoker, J. W., 1974, Detailed magnetic surveys in the Star Range, Beaver County, Utah: Utah Geology, v. 1, no. 1, p. 51-69. 1976, Principal facts for borehole gravity stations in the Columbia Gas 非20402 we11, Lincoln County, West Virginia: U.S. Geo1. Survey Open-File Rept. 76-593, 4 p., 1 table.

1977, Density variations in a quartz diorite determined from borehole gravity measurements, San Benito County, California: Log Analyst, v. 18, no. 2, p. 32-38.

Scholle, P. A., 1975, Applications of North Sea chalk diagenetic studies of petroleum exploration problems (abs.): AAPG-SEPM Ann. Mtg. Abs., Dallas, v. 2, p. 93-94. exploration problems (abs.): Am. Assoc. Petroleum Geologists Bull., v. 59, no. 11, p. 2197-2198.

AG 1976, Chalk diagenesis as a burial depth indicator (abs.): Geol. Soc. America Abs. with Programs, v. 8, no. 5, p. 261-262.

AG

1976, Diagenetic patterms of chalks (abs.): Am. Assoc. Petroleum Geologists Bul1., v. 60, no. 4, p. 719-720.

Scholle, P. A., 1977, Chalk diagenesis and its relation to petroleum exploration problems (oil from chalks--a modern miracle): Am. Assoc. Petroleum Geologists Bul1., v. 61, p. 982-1009.

1977, Deep-water carbonate sedimentology, diagenesis, and petroleum potential (abs.): Am. Assoc. Petroleum Geologists Bull., v. 61, p. 827.

AG ed., 1977, Geological studies on the B-2 COST Well, U.S. MidAtlantic Continental Shelf: U.S. Geol. Survey Circ. 750, 71 p.

AG 1977, Data summary and petroleum potential, in Scholle, P. A., ed., Geological studies on the COST No. B-2 we11, U.S. mid-Atlantic Outer Continental Shelf area: U.S. Geol. Survey Circ. 750, p. 8-14.

AG 1977, Sandstone petrography, in Scholle, P. A., ed., Geological studies on the COST No. B-2 we $\overline{11}$, U.S. mid-Atlantic Outer Continental Shelf area: U.S. Geol. Survey Circ. 750 , p. 32-34.

P Scholle, Peter A., and Arthur, Michael A., 1976, Carbon-isotopic fluctuations in Upper Cretaceous sediments--an indicator of paleooceanic circulation: Geol. Soc. America Abs. with Programs, v. 8, no. 6, p. 1089 . 
Scholle, P. A., and Kauffman, E. G., 1977, Paleoecological implications of stable isotope data from Upper Cretaceous limestones and fossils from the U.S. Western Interior, in North Amer. Paleonto1. Convention II, Abstracts volume: Jour. Paleontology, v. 51, no. 2 supp1., p. 24-25.

AG Scott, R. A., and Robbins, E. I., Palynomorph biostratigraphy, in Scholle, P. A., ed., Geological studies in the B-2 COST well, U.S. mid-Atlantic Outer Continental Shelf area: U.S. Geol. Survey Circ. 750, p. 41-43.

G Sellers, G. A., 1976, A possible role for nitrogen in the formation of petroleum deposits: AAPG-SEG-SEPM 51st Annual Meeting Programs, p. 23 (Pacific Section).

Shinn, E. A., 1974, Effects of oil field brine, drilling mud, cuttings and oil platforms on the offshore environment, in Marine environmental implications of offshore oil and gas development in Baltimore Canyon region of mid-Atlantic coast: Estuarine Research Federation of the Outer Continental Shelf Conf. and Workshop, 1974, p. 243-255. 1975, Polygonal cement sutures from the Holocene--A clue to recognition of submarine diagenesis (abs.): AAPG-SEPM Ann. Mtgs. Abs., Dallas, v. 2, p. 68.

Shinn, E. A., Halley, R. B., Hudson, J. H., and Lidz, B. H., 1977, The enigma of limestone compaction: Geology, v. 5, p. 21-24.

1977, Topographic control and accumulation rate of some Holocene coral reefs--South Florida and Dry Tortugas (abs.): Abstracts of Published Papers, Third Int'l Coral Reef Symposium, Miami, Fla.

Skipp, Betty, and Sandberg, C. A., 1975, Silurian and Devonian miogeosynclinal and transitional rocks of the Fish Creek Reservoir window, central Idaho: U.S. Geol. Survey Jour. Research, v. 3, no. 6, p. 691-706.

Smosna, R. A., Warshauer, S. M., Patchen, D. G., and Perry, W. J., 1975, Relation between Tonoloway Limestone environments of deposition and distribution of Salina evaporites in West Virginia (abs.): Am. Assoc. Petroleum Geologists Bull., v. 59, no. 9, p. 1739.

OB Spencer, C. W., 1975, Generalized geologic map of the centra1 Rocky Mountains, in Deep drilling frontiers in the Central Rocky Mountains-a symposium: Rocky Mtn. Assoc. Geologists Guidebook (inside front cover).

$\mathrm{OB}$

1975, Petroleum geology of east-central Utah and suggested approaches to exploration in Canyonlands Country: Four Corners Guidebook, 8th Field Conf., p. $263-275$. paleoenvironments of Western Interior Cretaceous marine and coastal deposits (abs.): Am. Assoc. Petroleum Geologists Bull., v. 60, no. 4, p. 724-725. 

of Cretaceous sandstones deposited in wave-dominated environments in Wyoming Geol. Assoc. 28th Ann. Field Conf. and Symposium, Sept. 1315, 1976, Casper, Wyoming (abs.): Symposium Abstracts, p. 3-4. Formation on west flank of Teapot Dome, Wyoming: Wyoming Geol. Assoc. Guidebook on Powder River Basin, 28th Annual Field Conf.

Swetland, P. J., and Clayton, Jerry L., 1976, Source beds of petroleum in the Denver basin (abs.): Am. Assoc. Petroleum Geologists Bull., v. 60 , no. 8, p. 1412 .

Swetland, P. J., Patterson, J. M., and Claypoo1, G. E., 1978, Source-bed evaluation of the Jurassic Twin Creek Limestone, Idaho-Wyoming thrust belt: Am. Assoc. Petroleum Geologists (in press).

Swetland, P. J., and Wehmiller, J. G., 1975, Lipid geochemistry of recent sediments from the Great Marsh, Lewes, Delaware: ACS Symposium Series No. 18, p. 2853-303.

Taira, A., and Scholle, P. A., 1977, Design and calibration of a photoextinction settling-tube for grain size analysis: Jour. Sed. Petrology, v. 47, p. 1347-1360.

Taylor, D. J., and Bayer, K. C., Geophysical studies, in Scholle, P., ed., Geological Studies on the B-2 COST well, U.S. mid-Atlantic Outer Continental Shelf: U.S. Geol. Survey Circ. 750.

PA Taylor, J. C., 1976, Estimating potential oil resources in the central California coastal zone, in Doyle, W. T., ed., Coastal marine studies: Santa Cruz, Calif. Univ. Spec. Pub. 3, p. 21-35.

PA 1976, Geologic appraisal of the petroleum potential of offshore southern California--the borderland compared to onshore coastal basins: U.S. Geol. Survey Circ. 730, 43 p. 1976, California's developed and undeveloped borderland (abs): Am. Assoc. Petroleum Geologists Bull., v. 60, no. 4, p. 727.

PA Taylor, J. C., Vedder, J. C., McLean, Hugh, 1975, Basement and Cenozoic volcanic rocks from offshore southern California (abs.): AAPG-SEGSEPM, Pacific Section Mtg., April 1975.

Taylor, M. C., and Cook, H. E., 1975, Trilobite biofacies of a Cambrian continental margin, western United States (abs.): Geol. Soc. America Abs. with Programs, v. 7, no. 7, p. 1294. Brigham Young Univ. Geology Studies, v. 23, pt. 2.

RAG Thomsen, H. L., 1975, The U.S. Geological Survey oil and gas resources appraisal group: Am. Assoc. Petroleum Geologists, Studies in Geology, no. 1 . 
Thomson, Alan, and Ryder, Robert T., 1976, Patterns of diachronous deepwater sedimentation as evidence for an actively shifting source terrane--Santa Margarite Formation and equivalent units (upper Miocene), southern Temblor Range, California (abs.): Geol. Soc. America Abs. with Programs, v. 8, no. 6, p. 1139-1140.

Tyler, T. F., 1974, A study of sand patterns resulting from current movements (abs.): Am. Assoc. Petroleum Geologists, v. 59, no. 5, p. 925.

OB

1976, Glenwood Canyon Member of the Dotsero Formation, west-central Colorado: Geol. Soc. America Abs, with Programs, v. 8, no. 5, p. 641 .

OB Tyler, T. F., and Campbe11, J. A., 1975, The Dotsero Formation, western Colorado: Mountain Geologist, v. 12, no. 4, p. 113-118.

PA Vedder, J. G., Arnal, R. E., Bukry, D., Baron, J., 1976, Preliminary descriptions of Pre-Quaternary samples, R. V. LEE, March 1976, Offshore Southern California: U.S. Geol. Survey Open-File Rept. 76-629.

PA Vedder, J. G., Beyer, L. A., Junger, A., Moore, G. W., Roberts, A. E., Taylor, J. C., Wagner, H. C., 1974, Preliminary report on the geology of the continental borderland of southern California: U.S. Geol. Survey Misc. Field Inv. Map MF-624.

PA Vedder, J. G., Green, H. G., Scott, E. W., Taylor, J. C., and others, 1976, A summary report of the regional geology, petroleum potential, environmental geology, and technology for exploration and development in the area of proposed Lease Sale 48, California continental borderland: U.S. Geol. Survey Open-File Rept. 76-787.

PA Vedder, J. G., and Howel1, D. G., 1976, Eogene strata of the southern group of Channel Islands, California, in Howell, D. G., ed., Aspects of the geologic history of the California continental borderland: Am. Assoc. Petroleum Geologists Misc. Pub. 24, p. 80-106.

PA 1976, Review of the distribution and tectonic implications of Miocene debris from the Catalina schist, California continental borderland and adjacent areas, in Howell, D. G., Aspects of the geologic history of the California continental borderland: Am. Assoc. Petroleum Geologists Misc. Pub. 24, p. 326-342.

PA Vedder, Jack, Taylor, Jim, Arnal, Bob, and Bukry, Dave, 1976, Map showing locations of selected pre-Quaternary rock samples from the California continental borderland: U.S. Geol. Survey Misc. Field Studies Map MF-737.

PA Von Huene, R., Smith, R., Hampton, M., Moore, G., and Dolton, G., 1976, A preliminary summary of petroleum potential, environmental geology, and the technology, time frame and infrastructure for exploration and development of the Western Gulf of Alaska: U.S. Geo1. Survey OpenFile Rept. 75-536. 
ES Wallace, L. G., and de Witt, Wallace, Jr., 1975, Maps showing selected deep wells drilled for oil or gas in the Appalachian basin: U.S. Geo1. Survey Misc. Inv. Map I-936.

AG Weed, E. G. A., Minard, J. P., Perry, W. J., Jr., Rhodehame1, E. C., and Robbins, E. I., 1974, Generalized pre-Pleistocene geologic map of the northern United States Atlantic continental margin: U.S. Geol. Survey Misc. Inv. Map I-861.

AG Weed, E. G. A., and Rossi, A. V., 1975, Data index maps for United States offshore areas: U.S. Geol. Survey Open-File Rept. 75-350.

PA Winkler, G., McLean, Hugh, and Plafker, George, 1976, Textural and mineralogical study of sandstones from the onshore Gulf of Alaska Tertiary province, southern Alaska: U.S. Geol. Survey Open-File Rept. 76-198.

OB Zachary, D. L., and Haley, B. R., 1975, Stratigraphic relationship between Bloyd Shale and the Atoka Formation, in Contributions to the geology of Arkansas Ozarks: Arkansas Geo1. Commission, p. 96-106.

$\mathrm{OB}$ 1975, Stratigraphic relationships between the Bloyd and Atoka Formations (Pennsylvanian) of Northern Arkansas, Chapt. in Contrib. to Geol. of Ark. Ozarks: Arkansas Geol. Comm., Symp. volume on the Ozark Mountains.

Ziegler, Willi, Sandberg, C. A., and Austin, R. L., 1974, Revision of Bispathodus group (Conodonta) in the Upper Devonian and Lower Carboniferous: Geologica et Palaeontologica, v. 8, p. 97-112. 1974, The Bispathodus group (Conodonta) in the Upper Devonian and Lower Carboniferous: Belgique Service Geol., Internat'1. Symp. on Belgian Micropaleontological Limits from Emsian to Visea, Namur, Sept. 1-10, 1974, publ. no. 20, 8 p. 


\section{APPENDIX IV}

Annotated List of Projects by Program

Regional petroleum geology

Onshore basin studies

Project Number

9410-00138 Devonian and Lower Mississippian rocks of western United States

C. A. Sandberg, Denver, Colorado

To investigate the petroleum geology, biostratigraphy, and regional correlation of these rocks in the Rocky Mountains and Great basin for valid correlations with the Upper Mississippi Valley. Ultimately, these data will provide petroleum migration dating through middle and lower Paleozoic rocks and determine source bed characteristics and locales favorable for future exploration.

9410-00537 Arkansas geological map co-op

B. R. Haley, Little Rock, Arkansas

To compile and publish a new colored geologic map of Arkansas; scale 1:500,000.

9410-01084 0i1 and Gas potential, Cretaceous, Western Interior C. W. Spencer, Denver, Colorado

To establish a regional Cretaceous and Paleocene stratigraphic framework of Western Interior structural basins including studies of depositional, diagenetic, and tectonic history of reservoirs, and the origin, migration, and accumulation of petroleum. Develop criteria and models for prediction of stratigraphic traps.

9410-01398 Petroleum geology, Paleozoic rocks, Cordilleran miogeosyncline C. A. Sandberg, Denver, Colorado

To provide a complete stratigraphic, tectonic, and petroleum source rock analysis for rocks of the middle and upper Paleozoic systems of the eastern Great basin and produce a basin analysis through a series of isopach, lithofacies, organic carbon, subcrop, paleogeologic, and paleostructure maps.

9410-01406 Tertiary oil basins of western United States

T. D. Fouch, Denver, Colorado

To delineate a11 parameters controlling oil generation, migration, and accumulation in the Piceance Creek, Uinta, Green River, Washakie Basins, and parts of the Great basin and outline potential future oil and gas developments in these frontier areas. 
To create a file of maps showing the distribution, thickness and significant facies patterns and controls on hydrocarbon accumulation of the western black, organic-rich shale--a relatively undeveloped hydrocarbon source.

9410-01874 Lower Upper Cretaceous stratigraphy and petroleum potential E. A. Merewether, Denver, Colorado

To refine the stratigraphy of these strata in Wyoming and from the data, identify potential hydrocarbon source rocks and reservoir beds, evaluate the petroleum potential of basins, and apply these findings to help interpret frontier exploration areas.

\section{Eastern black shale}

9410-01791 Stratigraphy of Devonian black shale in the Appalachian basin J. B. Roen, Reston, Virginia

To assemble all stratigraphic data for the ERDA Eastern Gas Shale Project and from these data prepare and generate regional stratigraphic, structural, and characterization studies including thickness, distribution, and lithofacies maps. State survey, university, and other Federal agency studies are to be monitored as a coordinating effort for the overall Black Shale Program.

9410-01828 Borehole gravity survey, Devonian black shale, Appalachian basin

J. W. Schmoker, Denver, Colorado

To obtain accurate density values in the Devonian Black Shale Program using the borehole gravity meter and relate these data to physical parameters of exploration interest.

9410-01844 Organic geochemical source bed study, Devonian black shale, Appalachian basin

G. E. Claypool, Denver, Colorado

To determine the amount, chemical type, and degree of thermochemical transformation of the Devonian black shale organic matter and to relate these patterns of variation to regional lithology patterns in relation to oil and gas occurrence.

9410-01845 Structural studies of the Devonian black shale; Appalachian basin

L. D. Harris, Reston, Virginia

To locate, evaluate, and analyze local and regional lineaments, fractures, faults, joints, and other related structural features that have caused natural subsurface fracturing and consequent reservoir development within the black shale necessary for gas production. 
9410-01846 Conodont maturation index, Devonian black shale, Appalachian basin

A. G. Epstein Harris, Reston, Virginia

To determine the degree of thermal maturation of the black shale through inexpensive, rapid conodont maturation studies and relate these data to gas productivity analysis. Such data will permit the subdivision of the basin into areas of little maturation (wet gas) and advanced maturation (dry methane).

9410-01847 Uranium and trace elements in Devonian black shale, Appalachian basin

J. S. Leventha1, Denver, Colorado

To determine the concentration and distribution of uranium and trace elements and relate these occurrences to the organic and sulfur chemistry to better understand the origin of deposits in certain depositional environments. Such occurrences may also serve as indicators to favorable and unfavorable areas of hydrocarbon accumulations.

9410-01898 Data storage and retrieval system, black shale T. S. Dyman (Acting), Denver, Colorado

To establish an information data base compatible with Petroleum Information's WHCS Data File of the Appalachian area and, also, capable of incorporating all data generated in the Eastern Black Shale Program. These data to be used for the development of computer generated maps.

9410-01900 Clay mineralogy--black shale J. W. Hosterman, Reston, Virginia

To use X-ray diffraction and fluorescence to determine the qualitative and quantitative clay minerals in the Devonian black shale and relate these data to regional stratigraphic correlations.

\section{Western tight gas sands}

9410-01907 Characterization of natura1 gas resources in 1ow-permeability sandstone, greater Green River Basin

C. W. Spencer, Denver, Colorado

To characterize the natural gas potential of subeconomic (low permeability) Tertiary and Cretaceous sandstone of the Green River Basin. This investigation will study distribution, thicknesses, trapping mechanisms, clay minerals, reservoir pressure data, and other characteristics. These studies will provide data for geologically based resource estimates and aid present and future recovery methods. 
9410-01911 Characterization of natural gas resources in low-permeability sandstones, Northern Great Plains

D. D. Rice, Denver, Colorado

To characterize the natural gas potential of subeconomic (low pressure, low permeability) Cretaceous sandstone of the Northern Great Plains. This investigation will study distribution, thicknesses, trapping mechanisms, clay minerals, reservoir pressure data, and other characteristics. These data will provide for geologically based resource estimates and aid present and future recovery methods.

9410-01912 Characterization of natural gas resources in low permeability sandstone, Piceance Creek and Uinta Basins

T. D. Fouch, Denver, Colorado

To characterize the natural gas potential of subeconomic (low permeability) Tertiary and Cretaceous sandstone of the Piceance Creek and Uinta Basin. This investigation will study distribution, thicknesses, trapping mechanisms, clay minerals, reservoir-pressure data, and other characteristics. These data will provide information for geologically based resource estimates and aid present and future recovery methods.

Northern Alaska petroleum geology

9410-01399 Regional petroleum geology, Alaska North Slope

K. J. Bird, Menlo Park, California

To establish a regional stratigraphic and structural framework and nomenclature. Within this framework to investigate the character, distribution, and relationship of petroleum source and reservoir rocks and the timing of petroleum generation and migration.

9410-01989 NPRA oil and gas source rock

To evaluate through organic geochemical analysis the potential for petroleum generation in National Petroleum Reserve A.

9410-01990 Cretaceous studies, North Slope Alaska

To study the environments of deposition of Cretaceous reservoir rock both in outcrop and in wells. To investigate the mineralogy of the rocks and the effects of burial on their reservoir properties. 
Topical petroleum geology

\section{Oil forming processes}

9410-00077 Organic geochemistry laboratory

T. G. Ging, Denver, Colorado

To provide laboratory facilities for direct project support by determination of analytical data on organicrich materials, both modern and ancient.

9410-01397 Geochemistry of sedimentary organic matter, crude oil, and natural gas

G. E. Claypoo1, Denver, Colorado

To evaluate and compare analytical methods for determination of source rock potential, degree of thermal maturity, and crude oil characterization, oil-source rock and oil-oil correlation, so as to select and develop methods most suited to branch applications in detailed research (extensive studies) or regional surveys for quick indication of organic properties (rapid, simple, techniques).

9410-01403 Site and process of crude oil generation

L. C. Price, Denver, Colorado

To investigate and establish the authenticity of crudeoil solubility in deep basin hot waters as a basis for of primary oil migration and petroleum origin.

9410-01676 Molecular characterization of complex organic mixtures and geochemical applications

D. E. Anders, Denver, Colorado

To develop and apply better methods for the detailed analysis of complex organic substances resulting in modern, computerized, automated techniques particularly for petroleum and sedimentary hydrocarbon mixtures.

9410-01677 Petroleum geochemistry of carbonate rocks

J. G. Palacas, Denver, Colorado

To assess the petroleum source rock potential of carbonates and to correlate these results with the analysis and characterization of carbonate reservoir crude oils.

9410-01872 Petrology of organic matter in sedimentary rocks and formation of petroleum and natural gas

N. H. Bostick, Denver, Colorado

To improve methods for microscopic determination of depostional and maturation characteristics of disbersed and solid organic materials in sedimentary rocks and the correlation between maturation and generation of petroleum and natural gas. 
Applied research on origin and distribution of natural gases D. D. Rice, Denver, Colorado

To perform specific analysis of the origins and distribution of all natural gases as related to their generation, migration, and accumulation and from these data develop an understanding which can be applied to hydrocarbon exploration in frontier areas.

Carbon cycle

P. A. Scholle, Reston, Virginia

To analyze deep-water limestones of the Tertiary, Cretaceous, and Jurassic. Detailed sampling will provide materials necessary to determine carbon isotopic composition, trace element composition, and organic carbon content. These data will be related to previous work in Europe and North America to establish a new correlation tool and predict time intervals of maximum petroleum source potential.

Sedimentary processes and reservoir rocks

\section{Reservoir rocks}

9410-01086 Petroleum reservoir rocks and seals, western United States Peter Scholle, Denver, Colorado

To determine and map porosity of selected sandstone units with future petroleum potential so as to identify factors which influence porosity, to relate porosity trends to structure and deposition, to determine feasibility of permeability estimates from porosity, and to synthesize these data into general maps of reservoir potential for future exploration.

9410-01391 Characteristics of chalk reservoirs P.A. Scholle, Reston, Virginia

To study chalk petroleum reservoirs using modern petrographic geochemical and well-log methods and determine origin and physical characteristics and predict subsurface porosity patterns. These studies can then be applied to apparent problems in chalk-reservoirs of OCS and onshore areas.

To coordinate and finance the research necessary for the evaluation of the Tri-State heavy oil and tar sands. This area in Missouri, Kansas, and Oklahoma will be investigated using surface and sub-surface methods. 
9410-00144 Stratigraphy of Supai-Hermit Formations, Arizona

E. D. McKee, Denver, Colorado

To describe and classify 1ithologic units of the Grand Canyon red bed series and, by tracing, to demonstrate lateral variations. Data from detailed red bed sedimentation studies will aid correlations with surrounding Permian environment and paleogeographic information for northern Arizona.

9410-00145 Sedimentation Laboratory

T. S. Ah1brandt, Denver, Colorado

To determine sedimentary features, through flume experiments, for bars, dunes, deltas, and related forms by which these structures can be recognized in ancient rocks.

9410-01407 Deposition and Diagenesis of Carbonate Sediments E. A. Shinn, Miami, Florida

To investigate sedimentary and diagenetic processes and patterns in carbonate continental shelf and margin environments which will provide data and criteria for recognition of productive carbonate reservoirs.

9410-01664 Sedimentation and diagenesis in deep-sea basins H. E. Cook, Menlo Park, California

To determine and compare the sedimentary process operating in modern and ancient continental slope and deep-sea environments for a better documentation of the nature, origin, and stratigraphic predictability of these sediments which have an important role in petroleum geology.

9410-01675 Aeolian sandstone reservoirs

T. S. Ahlbrandt, Denver, Colorado

To study the depositional characteristics of recent eolian deposits and apply the criteria developed to the subsurface to understand better, parameters which control fluid movements in ancient eolian deposits.

\section{Structural traps}

9410-01642 Appalachian Structural Patterns

W. J. Perry, Jr., Reston, Virginia

To develop a better understanding of the three-dimensional geometry and tectonic framework of the east-central Appalachian basin as related to potential petroleum migration paths and traps. 
To analyze in detail the thrust-fault deformation in the southern Valley and Ridge and the Appalachian Plateau areas and develop criteria for evaluating location and geometry of traps for hydrocarbon accumulation.

\section{Seismic stratigraphic studies}

9410-01401 Geophysical Properties of Sedimentary Layers

A. H. Balch, Denver, Colorado

To develop procedures, using modern seismic profiles, for interpreting and predicting vertical and lateral 1ithologic succession which can be applied to frontier basin petroleum resource appraisal.

9410-01663 Stratigraphic Geophysical Data Analysis

R. C. Anderson, Denver, Colorado

To establish a seismic data processing center and develop exploration techniques to integrate relevant exploration data for detecting, interpreting, and predicting local and regional stratigraphic variations.

9410-01669 Geologic Aspects of Geophysical Exploration for Stratigraphic Traps

R. T. Ryder, Denver, Colorado

To aid exploration by the petroleum industry by the development and application of procedures for detecting, interpreting, and predicting local and regional stratigraphic entrapment of hydrocarbons from modern seismic profiles.

\section{Geochemica1 detection}

9410-01404

Petroleum Geochemistry Prospecting Techniques

T. J. Donovan, Flagstaff, Arizona

To ascertain, evaluate and develop methods and techniques for the direct detection of petroleum resources on land and under sea by the study of various types of microseepages.

9410-01405 Basic Investigations of Remotely Detectable Deposits of Oi1 and Gas (BIRDDOG)

T. J. Donovan, Flagstaff, Arizona

To develop a rationale for a remote sensing-geochemical petroleum exploration system through the use of remotely acquired imagery and other high altitude and space acquired data for use in low-cost petroleum exploration. 
9410-01678 Development and Evaluation of Helium Detection as a Petroleum Geochemical Prospecting Technique

A. A. Roberts

To develop field analysis methods for the evaluation of helium microseepages associated with hydrocarbon deposits as a means of detecting undiscovered petroleum resources.

\section{Borehole gravity}

9410-00124 Mass properties of oil field rocks, California L. A. Beyer, Menlo Park, California

To determine porosities and bulk densities for certain marine and non-marine sedimentary rocks of different lithologies, fluid content, depth of burial, and structural position. The results are correlated with other physical properties as a means of refining geologic and geophysical methods of petroleum prospecting.

9410-01679 Application of borehole gravity meter to oil exploration J. W. Schmoker, Denver, Colorado

To develop borehole gravity tools and borehole velocity logging systems and apply them to measure and study physical rock properties in situ; to relate the results to geophysical and geological methods of exploration for hydrocarbons.

Resource Analysis

Resource appraisal group

9410-01089 Resource appraisa1 group - domestic

G. L. Dolton, Denver, Colorado

To evaluate oil and gas resources so as to revise previously estimated resources and to establish estimates of domestic offshore and foreign on and offshore resources.

9410-01670 0il and gas resource appraisal methodology

B. M. Miller, Denver, Colorado

To analyze and assess the different methods of appraising oil and gas resources and to adopt or develop an appraisal system which will provide a geologically oriented estimate of these undiscovered resources.

\section{Oil and gas data systems}

9410-01402

Core libraries

C. W. Spencer, Denver, Colorado

To develop and organize an integrated system of well sample and core repositories throughout the United States using existing State survey and university facilities as the basic network. 
W. W. Mallory, Denver, Colorado

To prepare an up-to-date oil and gas field map of the United States as an integral part of a map for North America, and to digitize and cross-reference this map with the Petroleum Data Systems Pool Data Bank.

9410-01803 0i1 and gas energy data systems T. S. Dyman, (Acting), Denver, Colorado

To evaluate all Survey and commercial data file systems and to inform and assist personnel in deriving maximum utilization and benefit from the files, computer processing equipment, and software. 